Bruk av tobakk, rusmidler og vanedannende legemidler i Norge

- hovedfunn fra SIRUS' befolkningsundersøkelse i 2012 

Elin K. Bye, Ellen J. Amundsen og Marianne Lund

Bruk av tobakk, rusmidler og

vanedannende legemidler i Norge

- hovedfunn fra SIRUS' befolkningsundersøkelse

i 2012

SIRUS-rapport nr. 6/2013

Statens institutt for rusmiddelforskning 
Statens institutt for rusmiddelforskning (SIRUS) er et selvstendig forskningsinstitutt under Helse- og omsorgsdepartementet. Sirus har som formål å utføre forskning, dokumentasjon og formidling omkring rusmiddelspørsmål, med særlig vekt på samfunnsvitenskapelige problemstillinger. Instituttet har nasjonalt kompetansebibliotek på rusmiddelfeltet og er nasjonalt kontaktpunkt for Det europeiske narkotikaovervåkningssenteret, EMCDDA

\section{Copyright SIRUS}

Oslo 2013

ISBN 978-82-7171-407-9

ISSN $1502-8178$

\section{SIRUS}

P.b. 565 Sentrum

0105 Oslo

Bes $\varnothing$ ksadresse: Øvre Slottsgt. 2 B

Telefon: 22340400

E-post: sirus@ sirus.no

www.sirus.no 


\section{Forord}

Kunnskap om status og utviklingstrekk for bruk av tobakk og rusmidler samles fra mange kilder. I 2012 startet SIRUS opp med en ny spørreundersøkelse til befolkningen, gjennomført av Statistisk sentralbyrå, og her rapporteres de første resultatene. Undersøkelsen og rapporteringen gjennomføres årlig.

Vi takker for et godt samarbeid rundt etablering og gjennomføringen av undersøkelsen med Statistisk sentralbyrå. Dessuten vil vi takke gode kolleger for hjelp med innhold og utforming av denne rapporten, spesielt Hilde Pape, Trond Nordfjærn, Ingeborg Rossow, Astrid Skretting, Karl Erik Lund, Elisabet Storvoll og Linda Solheim.

Oslo, november 2013

Elin K. Bye, Ellen J. Amundsen og Marianne Lund 



\section{Innhold}

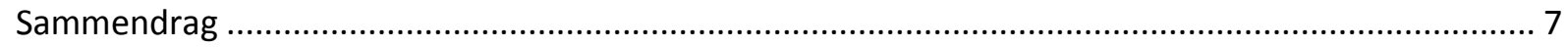

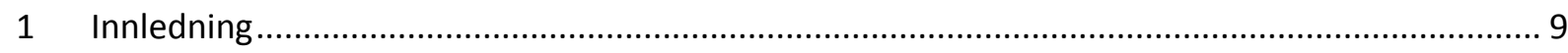

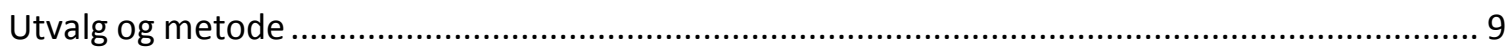

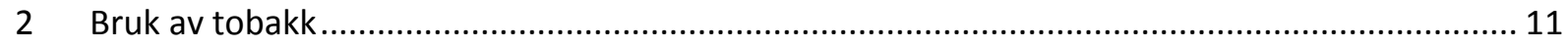

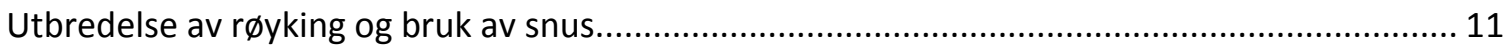

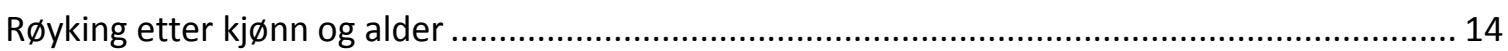

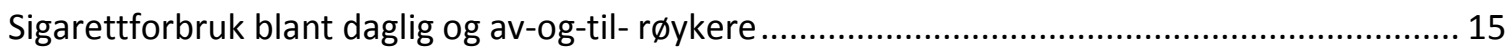

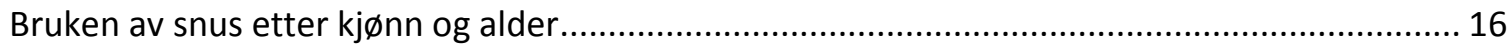

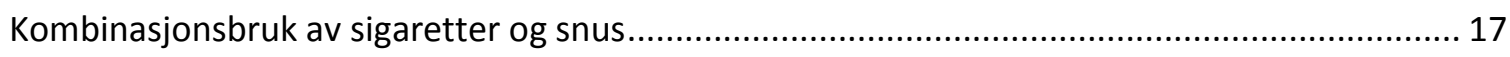

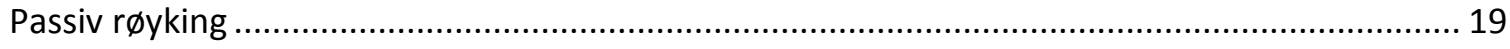

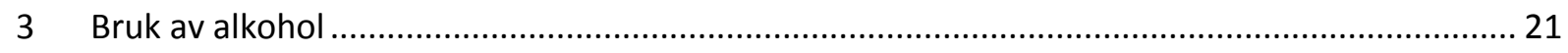

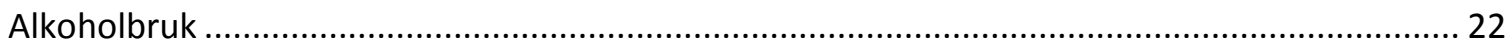

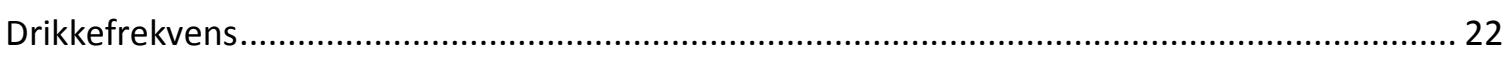

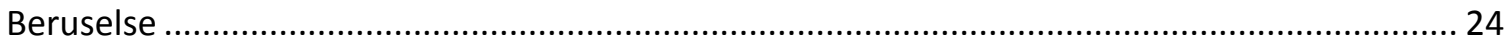

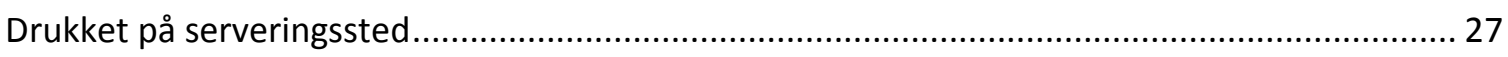

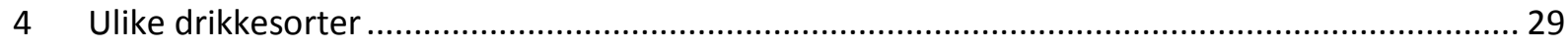

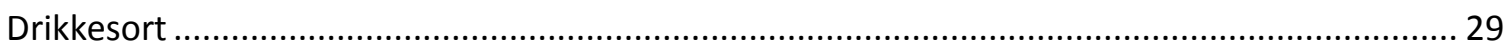

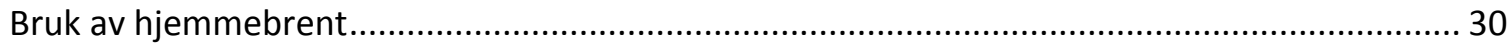

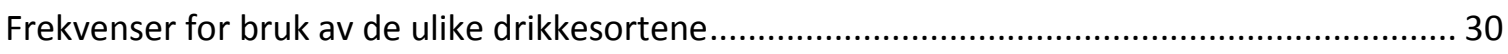

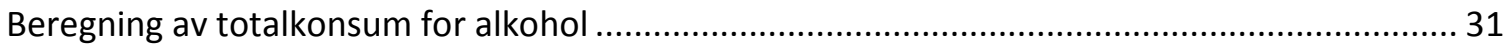

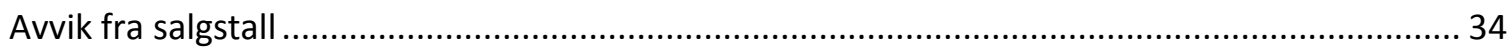

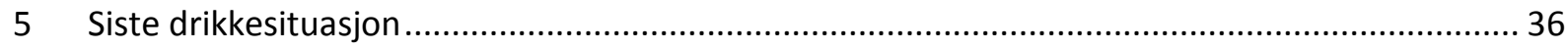

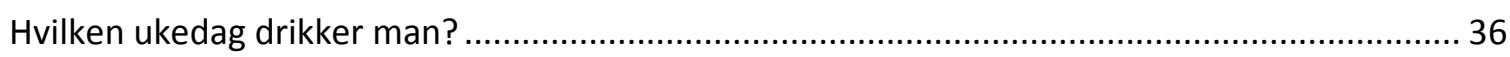

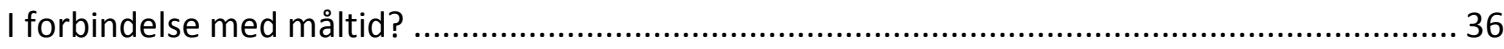

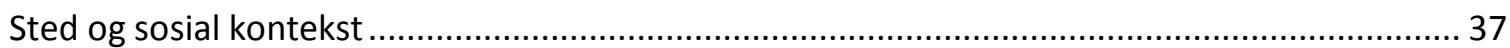

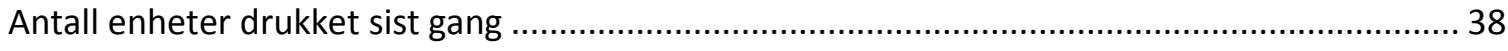

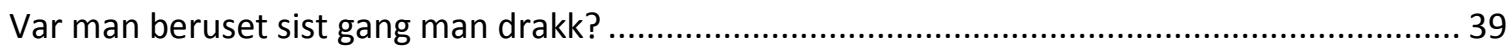

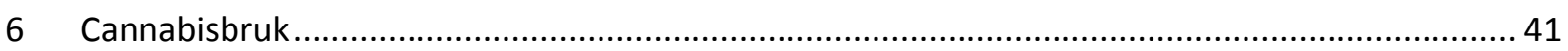

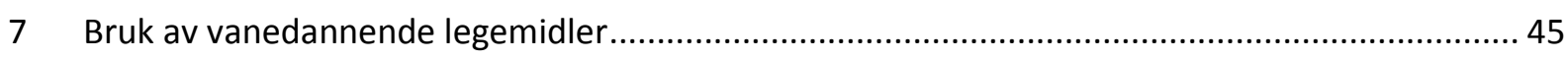

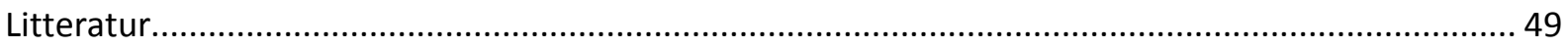

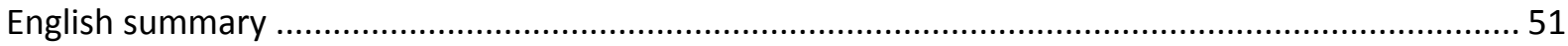


Vedleggstabeller til tobakkskapitlet.

Vedleggstabeller til alkoholkapitlene.

Vedleggstabeller til kapittel om cannabisbruk. 60

Vedleggstabeller til kapittel om bruk av legemidler 61 


\section{Sammendrag}

I denne rapporten presenteres hovedfunnene fra en befolkningsunders $\varnothing$ kelse om tobakks- og rusmiddelbruk gjennomført av Statistisk sentralbyrå på oppdrag fra SIRUS i 2012 (heretter kalt SIRUS 2012). Utvalget, som dekker aldersgruppen 16-79 år, ble trukket fra folkeregisteret, og svarprosenten var $53 \%$. Intervjuene ble gjennomført på telefon.

\section{Oppsummering tobakk}

Andelen dagligrøykere i befolkningen har gått gradvis ned, og nedgangen har vært markant siden årtusenskiftet. Av-og-til- røyking har derimot holdt seg stabilt på rundt $10 \%$ siden 1970-tallet. Resultatene fra SIRUS 2012 viste at $14 \%$ røykte daglig og $9 \%$ av og til. Det er omtrent like mange kvinner som menn som røyker.

Bruk av snus har $\varnothing \mathrm{kt}$ betydelig de siste ti-årene, og det er i hovedsak unge menn som bruker snus. I befolkningen som helhet er det $15 \%$ av menn og $4 \%$ av kvinner som bruker snus daglig, mens $6 \%$ av menn og $4 \%$ av kvinner bruker det av og til. Blant menn i aldersgruppen 16-24 år er det $31 \%$ som bruker snus daglig og $10 \%$ som bruker av og til. Det finnes noen brukere av både sigaretter og snus, men dette er ikke særlig utbredt; $5 \%$ av befolkningen er dobbeltbrukere.

Passiv røyking er undersøkt ved å spørre om det røykes innendørs hjemme hos respondenten. $14 \%$ opplyste at det ble røyket innendørs hjemme i en eller annen grad (daglig, månedlig eller sjeldnere), $7 \%$ rapporterte at dette skjedde på daglig basis. Innendørs røyking hjemme ble oftere rapportert av dagligrøykere, $35 \%$ av dagligrøykerne rapporterte dette. Av de som ikke røyker, sa $3 \%$ at det ble røykt innendørs hjemme hver dag.

\section{Oppsummering alkohol}

Omsetningen av alkohol har økt med 48 \% i perioden 1993 til 2008, men har gått noe tilbake etter dette. Økningen har i hovedsak kommet som følge av $\varnothing \mathrm{kt}$ salg av vin. Tidligere befolkningsundersøkelser har vist at det både har vært en $\emptyset$ kning i andelen som drikker alkohol og i andelen som drikker relativt ofte, men $\varnothing$ kningen i drikkefrekvens er ikke fulgt av en tilsvarende $\varnothing \mathrm{kning} \mathrm{i}$ andelen som ofte drikker seg beruset.

Resultatet fra SIRUS 2012 viser at ni av ti har drukket alkohol siste 12 måneder. Det er fremdeles slik at menn drikker oftere, de drikker mer og de er oftere beruset sammenlignet med kvinner. Det er de aller yngste (16-24 år) som har høyest konsum og som har høyest beruselsesfrekvens. Estimert totalkonsum er 3.8 liter ren alkohol siste år, hhv. 5.2 for menn og 2.5 for kvinner. Det er høyest konsum av liter ren alkohol i den yngste aldersgruppen (5.5) og lavest blant 65-79-åringer (2.6). 
Menn har drukket $\varnothing \mathrm{l}$ og brennevin langt oftere enn kvinner, mens kvinner har drukket vin noe oftere enn menn. Frekvensen for alkoholbruk er klart høyere blant de over 44 år, og frekvensen for bruk av vin er også markant høyere blant de over 44 år. Kvinners totalkonsum domineres av vin $(62 \%)$ og menns av $\varnothing 1$ (49\%).

Det er fremdeles slik at det er vanligst å drikke på fredag og lørdag. Syv av ti har drukket på privat sted (hjemme/hjemme hos andre), og man har i hovedsak vært sammen med ektefelle/kjæreste eller venner.

\section{Oppsummering cannabis}

Andel av befolkningen 16-64 år som har brukt cannabis noen gang øker jevnlig, mens bruk siste 12 måneder og siste fire uker (30 dager) har vært stabil siden 1985. I 2012 var det to av ti i aldersgruppen 16-64 år som rapporterte om bruk av cannabis minst en gang i løpet av livet, $3,4 \%$ hadde brukt det de siste 12 månedene og 1,5 \% hadde brukt cannabis i løpet av de siste fire ukene. Det er vanligere å bruke cannabis blant menn enn blant kvinner, og vanligst $\mathrm{i}$ aldersgruppen 16-24 år. Høyfrekvent bruk av cannabis ble rapportert av 0,3\%. Med høyfrekvent menes at de har brukt stoffet mer enn 20 dager de siste fire uker.

\section{Oppsummering legemidler}

I 2012 rapporterte en av ti personer i aldersgruppen 16-79 år at de hadde brukt reseptbelagte sovemidler de siste 12 måneder. Flere kvinner enn menn rapporterte om slik bruk. Fra 25 år var andelen personer som brukte sovemidler større jo eldre personene var.

Seks prosent hadde brukt reseptbelagte beroligende legemidler de siste 12 månedene. Vi fant ingen kjønnsforskjell i bruk. Også for beroligende midler var andelen personer som hadde brukt dette større jo eldre personene var fra 25 års alder.

En av fire hadde brukt reseptbelagte smertestillende legemidler, og vi fant ingen kjønnsforskjell for denne type legemidler heller. Andel av personer som hadde brukt smertestillende midler var større i aldersgruppen 35-44 år enn for de yngre, mens omfanget var det samme for alle personer over 45 år.

Daglig og langvarig bruk (over 3 måneder siste 12 måneder) omfattet 1.7 prosent av befolkningen 16-79 år for reseptbelagte sovemidler, 1.3 prosent for reseptbelagte beroligende midler og 3.4 prosent for reseptbelagte smertestillende midler. 


\section{Innledning}

Statens institutt for rusmiddelforskning (SIRUS) har siden 1962 foretatt intervjuer av representative utvalg av den norske befolkningen for å få kunnskap om nordmenns bruk av alkohol. Fra 1973 ble det inkludert spørsmål om mengde som ble drukket av de ulike alkoholsortene, og hvor mye man drakk ved siste drikketilfelle. Undersøkelsene er basert på personlig intervju, og ble gjentatt i 1979, 1985, 1991, 1994, 1999 og 2004. Hovedresultatene for alkohol finnes i rapporten «Det norske drikkemønsteret. En studie basert på intervjudata fra 1973-2004» (Horverak og Bye 2007) samt i «Rusmidler i Norge 2006» (Bryhni 2006). Spørsmål om bruk av marihuana/hasj, samt sovemidler og beroligende legemidler ble tatt med fra 1985. Spørsmål om bruk av tobakk har ikke tidligere vært samlet inn på befolkningsnivå av SIRUS. SIRUS får ansvaret for overvåkning av tobakksbruk i befolkningen fra og med 2014. Dette ansvaret har tidligere ligget hos Helsedirektoratet, som siden 1973 har samlet inn data via Statistisk sentralbyrå (Tobakksbruksundersøkelsen). Dette vil bli en egen undersøkelse i tillegg til den som presenteres her.

Befolkningsundersøkelsen basert på personlig intervju ble gjentatt i 2009, men svarprosenten var så lav at dataene ikke var egnet for publisering. I 2012 inngikk SIRUS derfor et samarbeid med Statistisk sentralbyrå om en ny årlig befolkningsunders $\varnothing$ kelse. De nye unders $\varnothing$ kelsene foretas på telefon, og inkluderer spørsmål om bruk av tobakk/snus, alkohol, narkotika og vanedannende legemidler.

Denne rapporten inneholder hovedfunnene fra 2012- unders $\varnothing$ kelsen, og gir en deskriptiv oversikt over utbredelse og forbruk av de ulike substansene. Alle resultater presenteres i hovedsak etter kjønn og alder, og vi ser på fordelinger for hele utvalget (der ikke annet er nevnt). For å lette gjennomgangen vil den foreliggende undersøkelsen bli betegnet SIRUS 2012.

\section{Utvalg og metode}

Et representativt utvalg ble trukket fra folkeregisteret og intervjuet på telefon, etter at de i forkant var tilsendt et informasjonsbrev om unders $\varnothing$ kelsen. Foreldre til respondenter 16-17 år mottok et eget informasjonsbrev om at barnet var trukket ut til undersøkelsen. Utvalget ble trukket blant personer i alderen 16-79 år, og ble trukket disproporsjonalt (med ulik sannsynlighet/ med en overrepresentasjon) for å sikre flere observasjoner fra aldersgruppen 16-30 år (se tabell 1 for nøkkeltall). Det ble trukket et tilfeldig utvalg av 3000 personer i alderen 16-79 år og et ekstra tilfeldig utvalg av 700 personer i alderen 16-30 år (alderen regnet pr. 01.01.2012). Trekkdesignet og frafall medfører at resultatene måtte vektes for alder, kjønn, utdanning og landsdel for å sikre at tallene som gis i denne rapporten er representative for befolkningen. 
Undersøkelsen oppnådde en svarprosent på $53.3 \%$, totalt 1947 respondenter. Den viktigste årsaken til manglende svar var at man ikke oppnådde kontakt med personene i utvalget i løpet av unders $\emptyset$ kelsesperioden. I utgangpunktet skulle alle intervjuene foretas i perioden mai-juni 2012. SSB ble imidlertid rammet av streiken blant kommune- og statsansatte (24. mai til 7. juni 2012) og fikk redusert kapasitet i intervjuavdelingen. Feltperioden måtte derfor utvides, og de resterende intervjuene ble foretatt i perioden 24. 09 - 03.11. 2012. Tabell 1 viser nøkkeltallene for undersøkelsen.

Tabell 1. Nøkkeltall

\begin{tabular}{|l|c|c|}
\hline \multicolumn{1}{|c|}{ Nøkkeltall } & Antall & Prosent \\
\hline Utvalg (personer trukket ut for intervju) & 3700 & 100 \\
\hline Avgang (døde, personer bosatt i utlandet) & 48 & 1,3 \\
\hline Bruttoutvalg & 3652 & 100 \\
\hline Frafall & 1705 & 46,7 \\
\hline Nettoutvalg (personer oppnådd intervju med) & 1947 & 53,3 \\
\hline Innsamlingsmetode: Telefonintervju & & \\
\hline Intervjutid: Varierende & & \\
\hline Feltperiode: & 24.09-03.11. 2012 \\
\hline
\end{tabular}

Alle resultater er vist etter kjønn og aldersgrupper. Fordelinger med bare to kategorier er testet ved hjelp av forskjeller i andeler, mens med flere kategorier er det benyttet kji-kvadrat-tester. Det er benyttet t-tester for forskjeller i gjennomsnitt. Der det i teksten opplyses om forskjeller, er disse statistisk signifikante på fem prosent nivå. Dette betyr at forskjellen er større enn det vi kan tilskrive tilfeldigheter man kan vente å finne når vi analyserer et utvalg, og ikke tall for hele befolkningen.

Selvrapportert bruk av alkohol og andre rusmidler eller substanser stemmer ikke nødvendigvis med hva personer faktisk har brukt. Dette er ikke alltid en bevisst over- eller underrapportering fra personer som skal rapportere. Et viktig resultat fra tidligere forskning er at personer har en tendens til å rapportere i retning av det som er sosialt ønskverdig (Del Boca og Darkes, 2003). Hva som er sosialt ønskverdig, vil variere med situasjonen personen er i, og illegale rusmidler blir trolig underrapportert i enda større grad enn legale substanser som alkohol og tobakk. I denne rapporten brukes termen 'bruk av rusmidler' synonymt med 'selvrapportert bruk av rusmidler'. Det er også viktig å huske at data om bruk av rusmidler og tobakk basert på et utvalg av befolkningen kan inneholde andre feilkilder. For eksempel vil personer med høyt forbruk av narkotika ofte være marginalisert og uten permanent bolig og kan ha perioder i behandling eller i fengsel. Det er derfor mindre sannsynlig at disse svarer på spørreunders $\varnothing$ kelser. 


\section{Bruk av tobakk}

Dette kapittelet omhandler forekomst av sigarettrøyking og snusbruk. I sigarettrøyking inngår både konsum av filtersigaretter og rulletobakk. I tillegg presenteres noen resultater om utbredelse av innendørs røyking hjemme. Resultatene fra SIRUS 2012 vil bli sammenlignet med Tobakksbruksundersøkelsen som hvert år har blitt samlet inn av SSB på vegen av Helsedirektoratet. Hovedforskjellen mellom SIRUS 2012 og Tobakksbruksunders $\varnothing$ kelsen er at førstnevnte har et noe større utvalg med oversampling av den yngste gruppen, det er ikke skilt mellom fabrikkframstilte eller egenrullete sigaretter, og det spørres også noe ulikt blant annet når det gjelder forbruk av sigaretter blant av-og-til- røykere. Aldersspennet i SIRUS 2012 er 16-79 år, mens Tobakksbruksundersøkelsen viser resultater for gruppen 16-74 år. Tabeller med prosent og tallbasis finnes i vedlegg.

\section{Utbredelse av røyking og bruk av snus}

Figur 2.1 viser endringer i røykevaner i perioden 1973-2012 i Norge basert på de årlige Tobakksbruksunders $\varnothing$ kelsene til Helsedirektoratet. Andel som rapporterer at de røyker daglig har gått betydelig ned, og nedgangshastigheten har vært størst etter 1990. Den selvrapporterte forekomsten av av-og-til- røyking har holdt seg forholdsvis stabil i hele perioden. Tobakksbruksundersøkelsen viste at $16 \%$ oppga at de røykte daglig i 2012, mens $10 \%$ rapporterte at de røykte av og til.

Disse tallene samsvarer godt med SIRUS 2012 der $14 \%$ oppga at de røykte daglig, mens $9 \%$ svarte de røykte av ogtil (Figur 2.2). Totalt oppga 22,9 \% at de røykte i Norge. Omregnet til antall personer utgjør dette om lag 865000 røykere. Andelen forhenværende røykere var 39 $\%$ - omtrent like stor som andelen aldri-røykere $(38 \%)$. 
Figur 2.1 Andel av befolkningen 16-74 år som røyker daglig eller av og til, treårig glidende gjennomsnitt 1973-2012. SSB/Helsedirektoratet

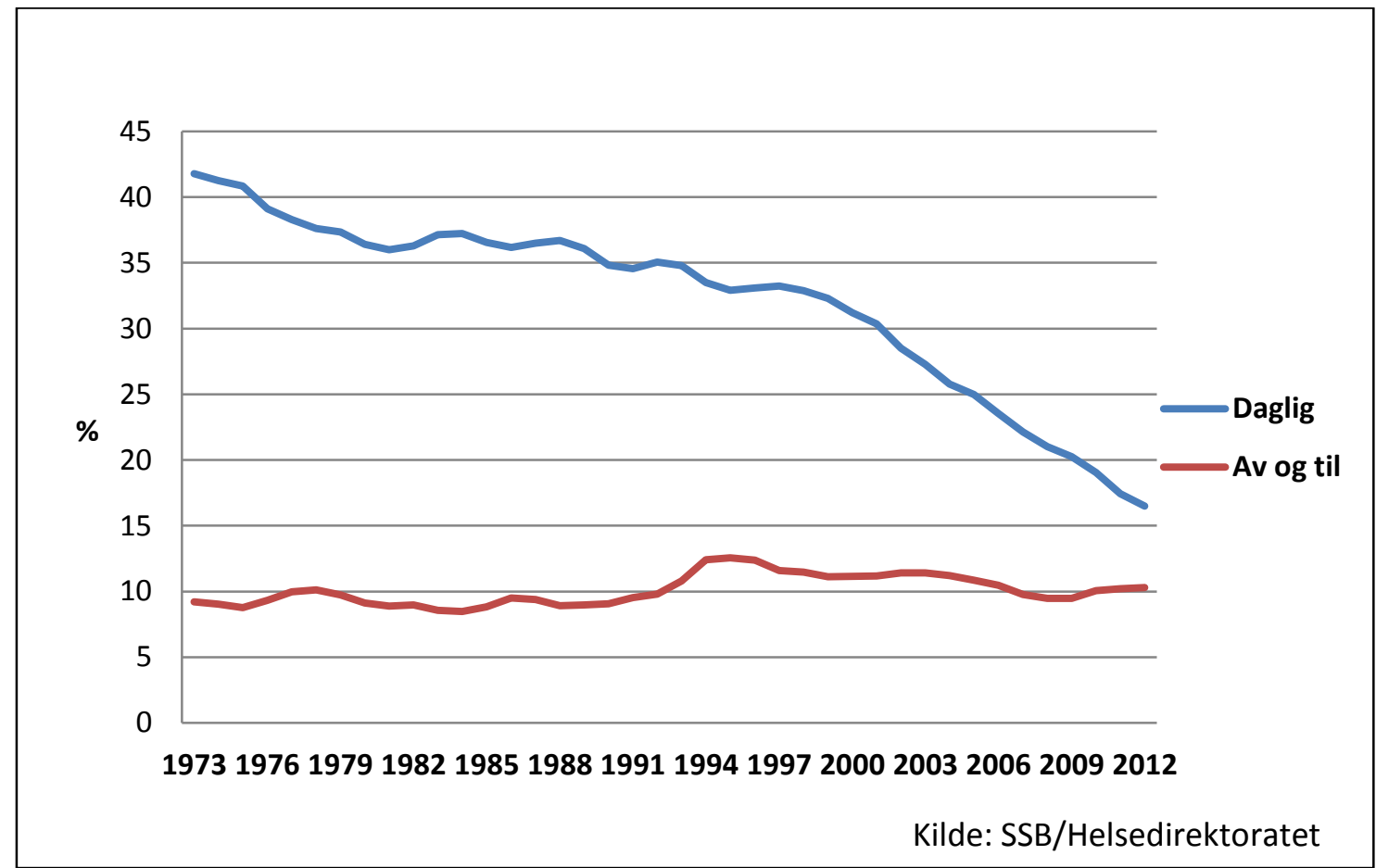

Figur 2.2 Andel av befolkningen 16-79 år etter røykestatus. 2012. N=1949

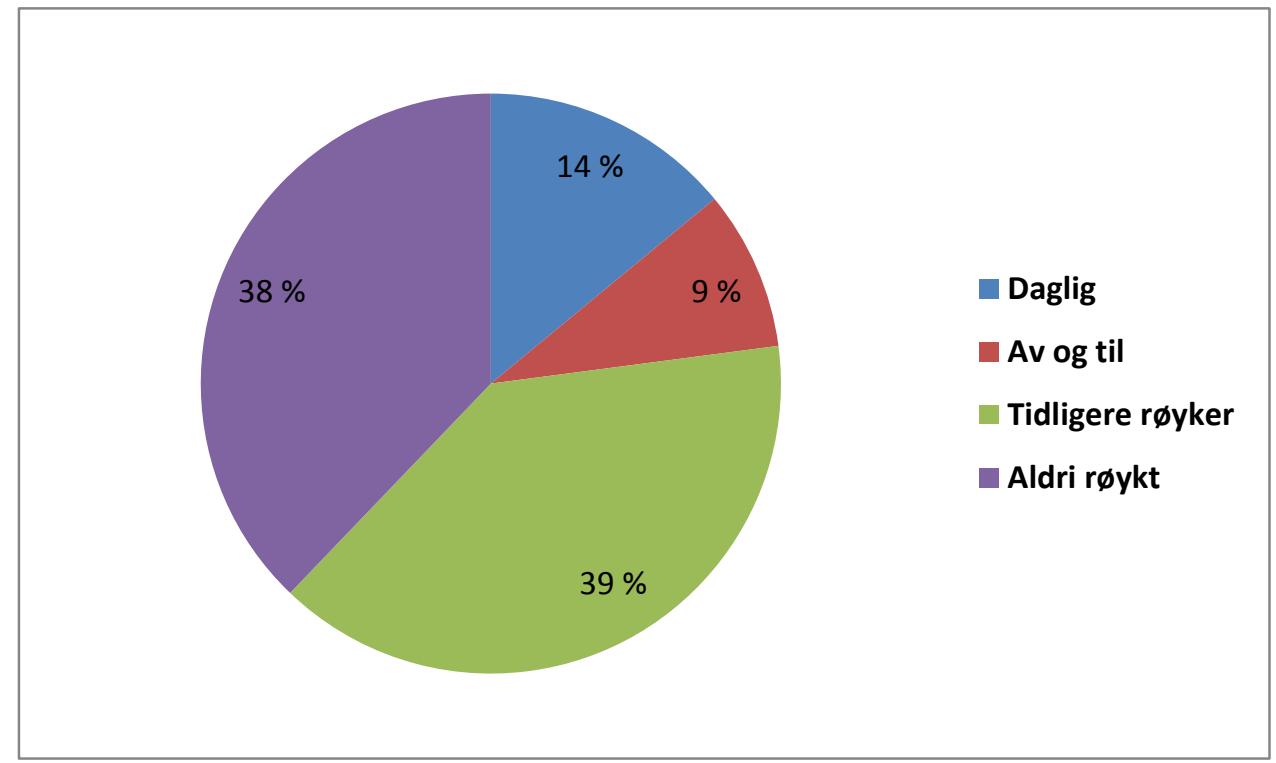


Figur 2.3 viser at befolkningens bruk av snus har $\emptyset \mathrm{kt}$ i perioden 1985-2012. Stigningen har vært størst for daglig snusbruk. Også denne figuren er basert på data fra Tobakksbruksundersøkelsene. SIRUS 2012 viste at $10 \%$ oppga å bruke snus daglig, mens 5 $\%$ rapporterte om snusbruk av og til (Figur 2.4). Resultatet var i samsvar med Tobakksbruksundersøkelsen, som samme år viste at henholdsvis $9 \%$ og $4 \%$ brukte snus daglig eller av og til (Helsedirektoratet 2013). Figur 2.3 viser til treårig glidende gjennomsnitt, og tallene for 2012 er derfor noe annerledes her.

Figur 2.3 Andel av befolkningen 16-74 år som bruker snus daglig eller av og til, treårig glidende gjennomsnitt 1973-2012. SSB/Helsedirektoratet

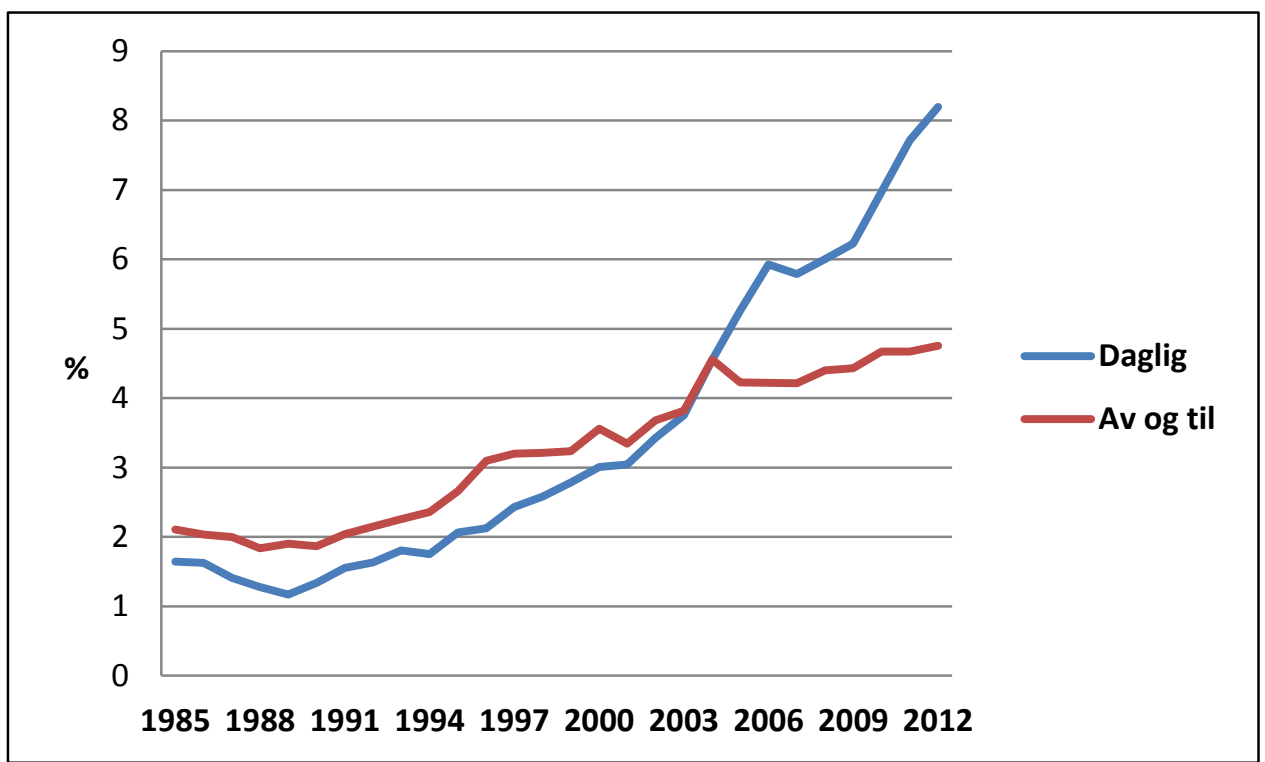

Figur 2.4 Andel av befolkningen 16-79 år etter snusbrukerstatus. $\mathrm{N}=1947$

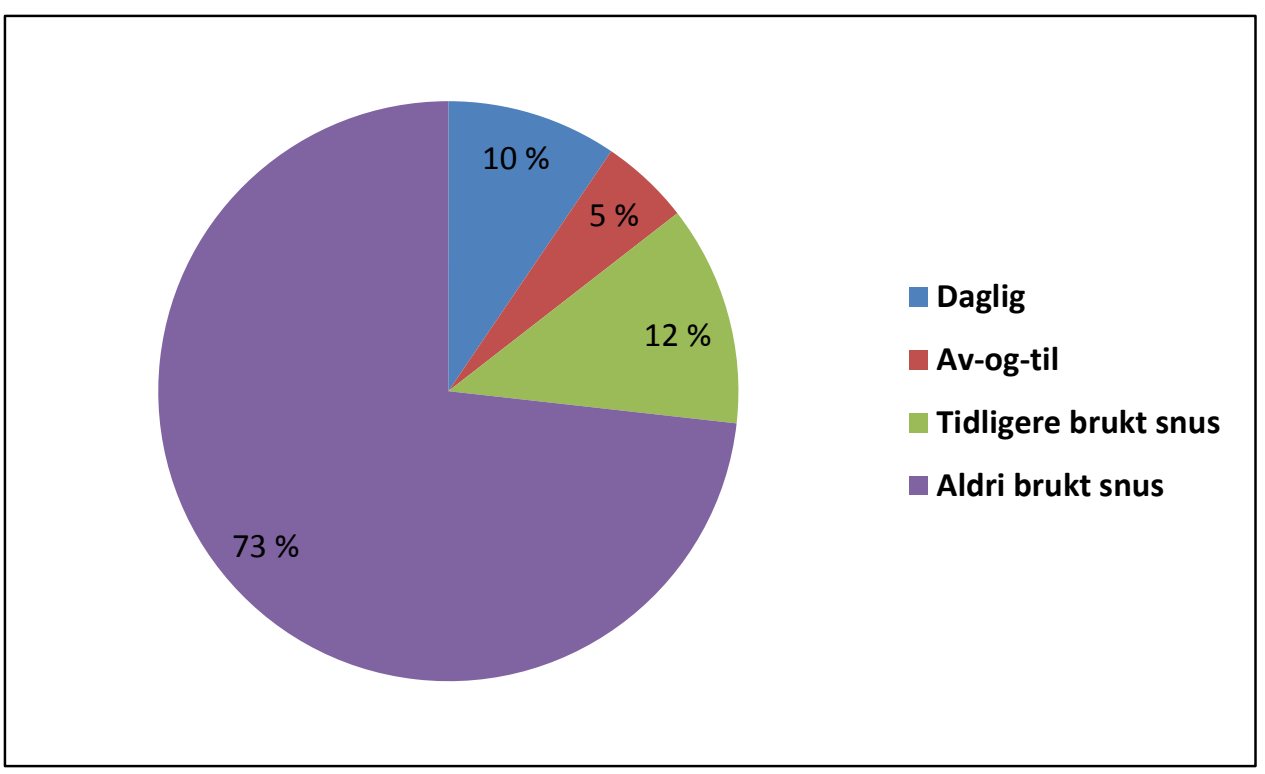




\section{Røyking etter kjønn og alder}

Figur 2.5 viser at like mange menn som kvinner oppga å røyke daglig eller av og til. Det ble imidlertid observert en kjønnsforskjell i andelen som aldri hadde røykt. Flere kvinner enn menn rapporterte at de ikke hadde røykt verken på undersøkelsestidspunktet eller tidligere. Figur 2.6 viser røykestatus i ulike aldersgrupper. Andelen som sier de aldri har røykt synker med stigende alder, samtidig som andelen forhenværende røykere stiger med alderen. Av-ogtil- røyking er mindre vanlig i de eldre aldersgruppene, mens dagligrøyking er mest utbredt i aldersgruppen 45-54 år. En mer detaljert beskrivelse av røykestatus blant menn og kvinner i ulike aldersgrupper, gis i vedleggstabeller til Figur 2.6.

Figur 2.5 Andel av befolkningen 16-79 år etter røykestatus. Kvinner og menn. N=1948

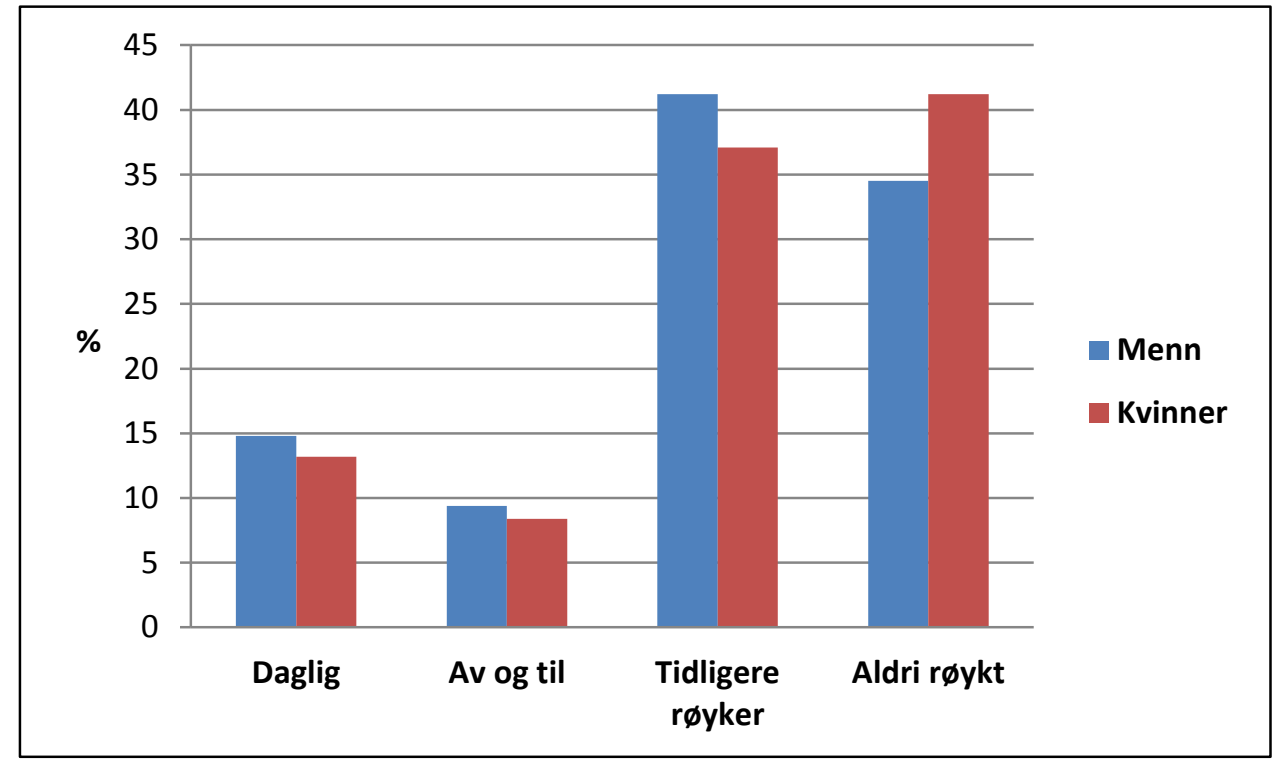


Figur 2.6 Andel av befolkningen 16-79 år etter røykestatus. Aldersgrupper. $\mathrm{N}=1949$

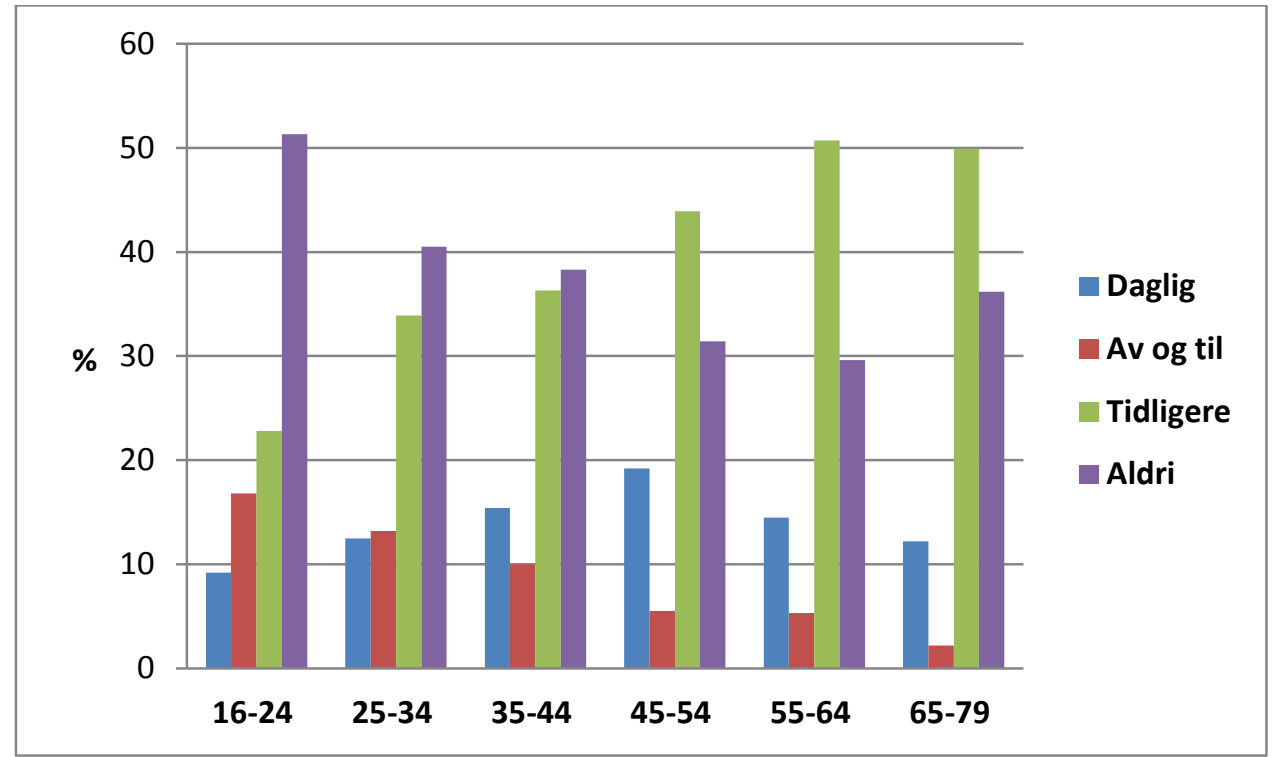

Note: Eksakte prosentandeler oppgis i vedleggstabell.

\section{Sigarettforbruk blant daglig og av-og-til- røykere}

Det gjennomsnittlige forbruket av sigaretter per dag for de som røyker daglig $(n=272)$ var 12,4. Menn røykte flere sigaretter per dag $(13,9)$ sammenlignet med kvinner $(10,7)$. Disse tallene var konsistente med resultatene fra Tobakksbruksundersøkelsen, som fant et gjennomsnittlig sigarettforbruk på 10,8 for kvinner, og 14,6 for menn blant dagligrøykere Helsedirektoratet 2013). Figur 2.7 viser det daglige forbruket av sigaretter i ulike aldersgrupper. Selv om det er noe ulik rapportering i antall sigaretter per dag i de ulike aldersgruppene, foreligger det ikke statistisk signifikante forskjeller. 


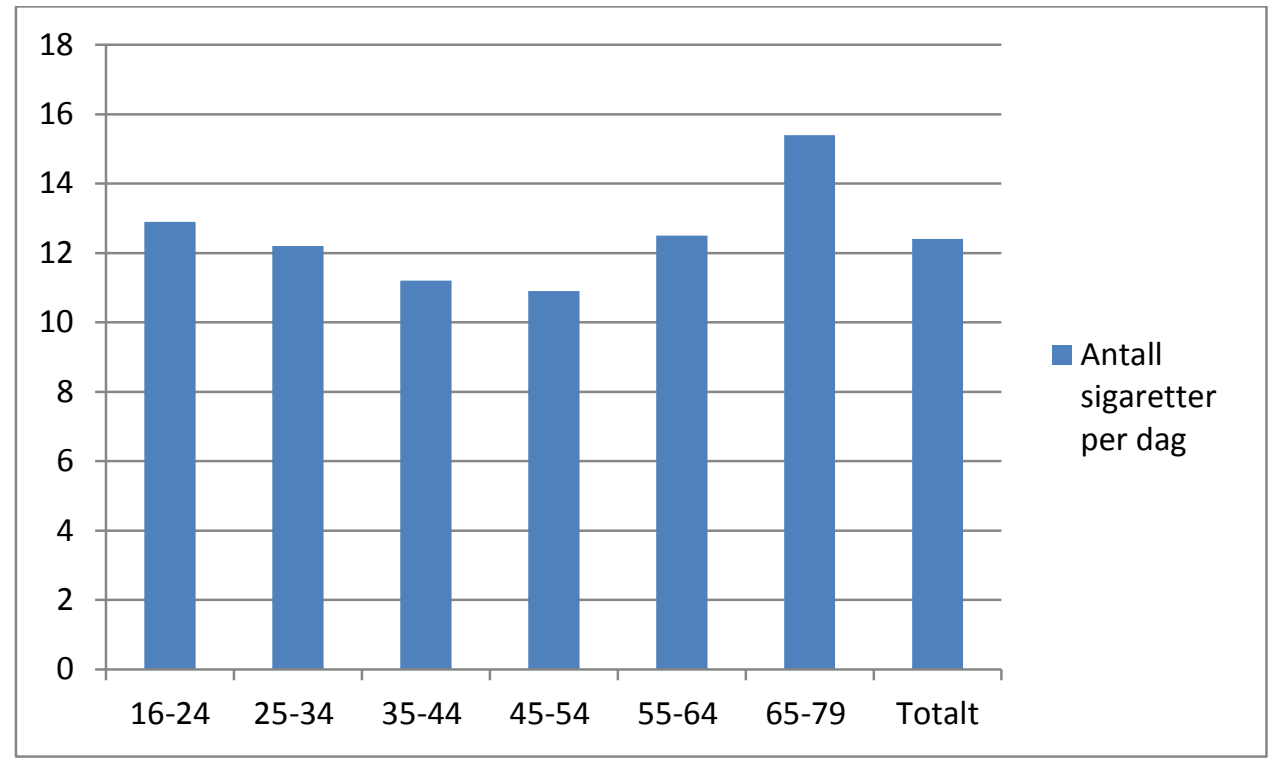

Av-og-til- røykere som rapporterte at de røykte minst ukentlig (N=55) ble bedt om å oppgi sitt ukentlige forbruk av sigaretter. Det var ingen kjønnsforskjell i sigarettforbruk blant denne gruppen av-og-til- røykere. Menn oppga at de røykte 16,4 sigaretter per uke, mens tilsvarende resultat for kvinner var 16,6. For røykere med enda mer lavfrekvent forbruk av sigaretter, dvs. de som oppga at de røykte sjeldnere enn en gang i uken $(\mathrm{N}=116)$, ble siste måneds forbruk av sigaretter registrert. Denne gruppen røykte i gjennomsnitt 8,8 sigaretter i løpet av måneden, og heller ikke her var det noen forskjell mellom menn $(9,2)$ og kvinner $(8,3)$. Ved beregning av alle av-og-til- røykernes ukentlige forbruk, ligger dette på 6,8 sigaretter per uke. Dette er lavere enn det som Tobakksbruksundersøkelsen rapporterer for av-og-til- røykere (10,6 sigaretter per uke), og kan skyldes ulike målemetoder i de to undersøkelsene.

\section{Bruken av snus etter kjønn og alder}

Snus brukes i all hovedsak av menn. Det har vært en jevn økning i snusbruk blant menn de siste 20 årene, og de siste ti årene er det også registrert en svak økning i snusbruk blant kvinner (Helsedirektoratet 2013). I SIRUS 2012 var det $15 \%$ av menn som brukte snus daglig, sammenlignet med $4 \%$ blant kvinner (Figur 2.8). Av-og-til- bruken av snus var $6 \%$ blant menn og $4 \%$ blant kvinner. Fordi snusbruk er mest utbredt blant menn, viser Figur 2.8 forekomst fordelt på aldersgrupper for menn utelukkende. Bruk av snus var mest utbredt i de yngste aldersgruppene, mens andelen som hadde sluttet med snus var høyest $\mathrm{i}$ aldersgruppen 25-34 år. Blant kvinner i aldersgruppen 16-24 år $(n=150)$ var det 16,7 \% som brukte snus daglig, $14 \%$ brukte av og til. Få kvinner over 25 år bruker snus (se vedleggstabell til figur 2.9). 
Figur 2.8 Andel av befolkningen 16-79 år etter snusbrukerstatus. Kvinner og menn. N= 1946

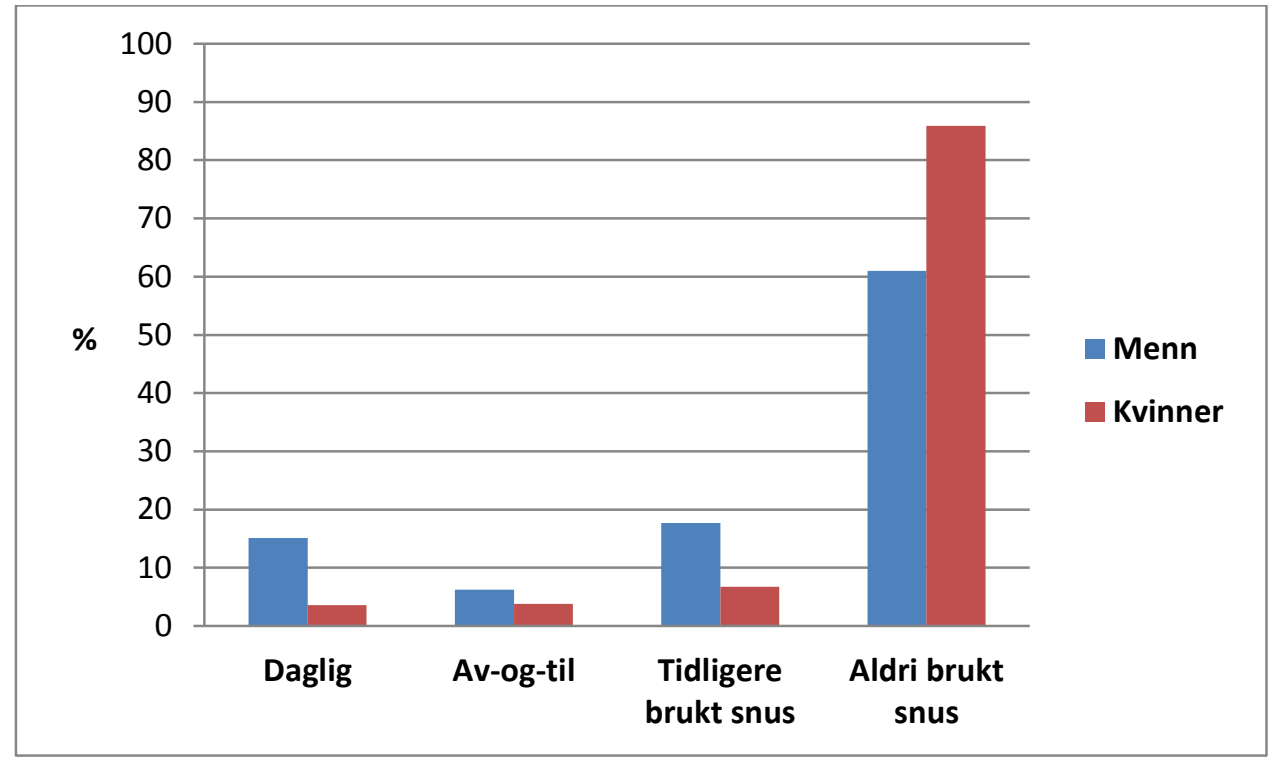

Figur 2.9 Andel menn i alderen 16-79 etter snusbrukerstatus. Aldersgrupper

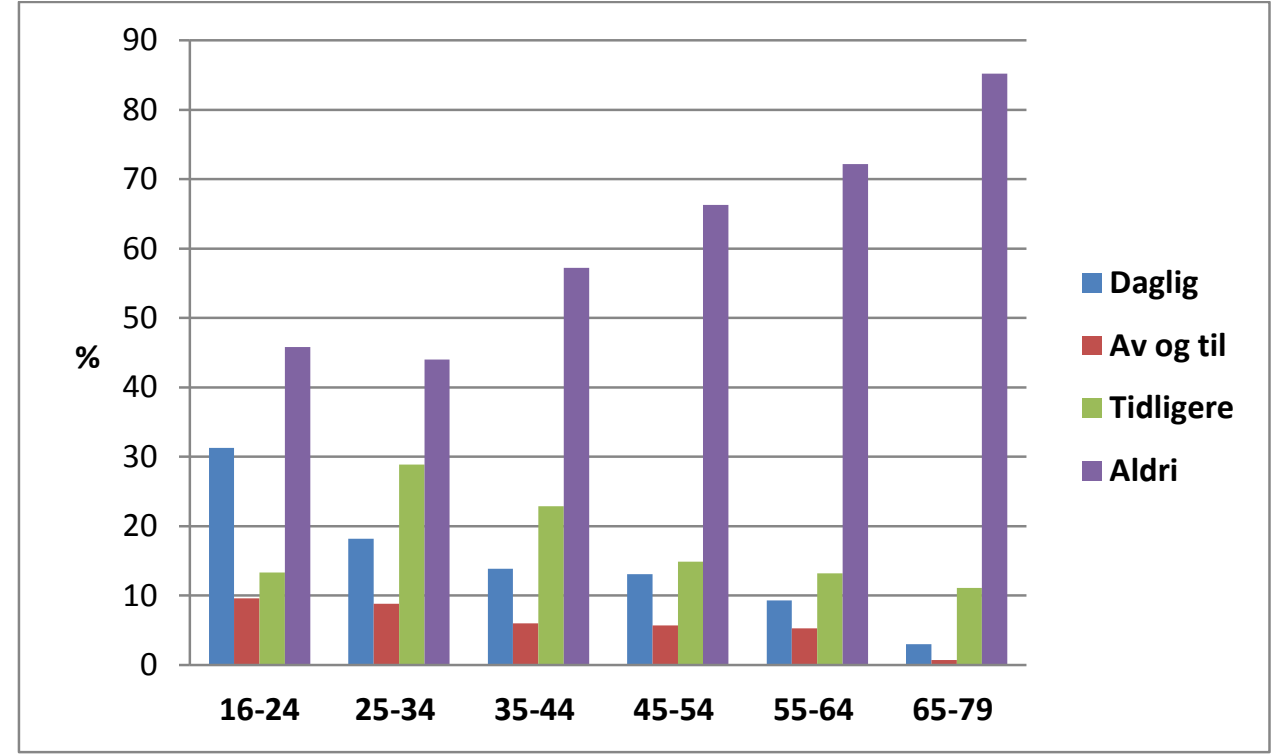

Note: Eksakte prosentandeler oppgis i vedleggstabell.

\section{Kombinasjonsbruk av sigaretter og snus}

Figur 2.10 viser at $18 \%$ av befolkningen var eksklusive røykere, dvs. de røyker daglig eller av og til, men snuser ikke. Tilsvarende tall for de som er eksklusive snusbrukere (daglig eller av og til) var $9 \%$. Dobbeltbruk vil si at de kombinerer bruk av snus og sigaretter, og at bruksintensitet for hvert av produktene er av og til eller daglig. I denne undesøkelsen var $5 \%$ dobbeltbrukere av snus og sigaretter. I en annen norsk studie ble $6,8 \%$ observert som 
dobbeltbrukere, og $1 \%$ brukte både snus og sigaretter daglig (Lund \& McNeill, 2013). Den mest vanlige årsaken til dobbeltbruk antas å være at røykere går over til snus fordi de enten $\emptyset n$ sker å redusere sigarettforbruket, slutte helt, eller bruker snus på steder hvor det ikke er lov å røyke. Tabell 2.1 viser andelen som røyker av alle som bruker snus (daglig eller av og til, $\mathrm{n}=282$ ), mens tabell 2.2 viser andelen som bruker snus av alle som røyker (daglig eller av og til, $n=446)$. Det var flere tidligere røykere i gruppen av snusbrukere (46\%) enn det var tidligere snusere i gruppen av røykere (20\%). Dette ble også observert i en annen studie (Lund, Scheffels, McNeill 2011).

Figur 2.10 Andelen av befolkningen 16-79 år som er eksklusive røykere, eksklusive snusbrukere, dobbeltbrukere eller som ikke bruker tobakk. $\mathrm{N}=1947$

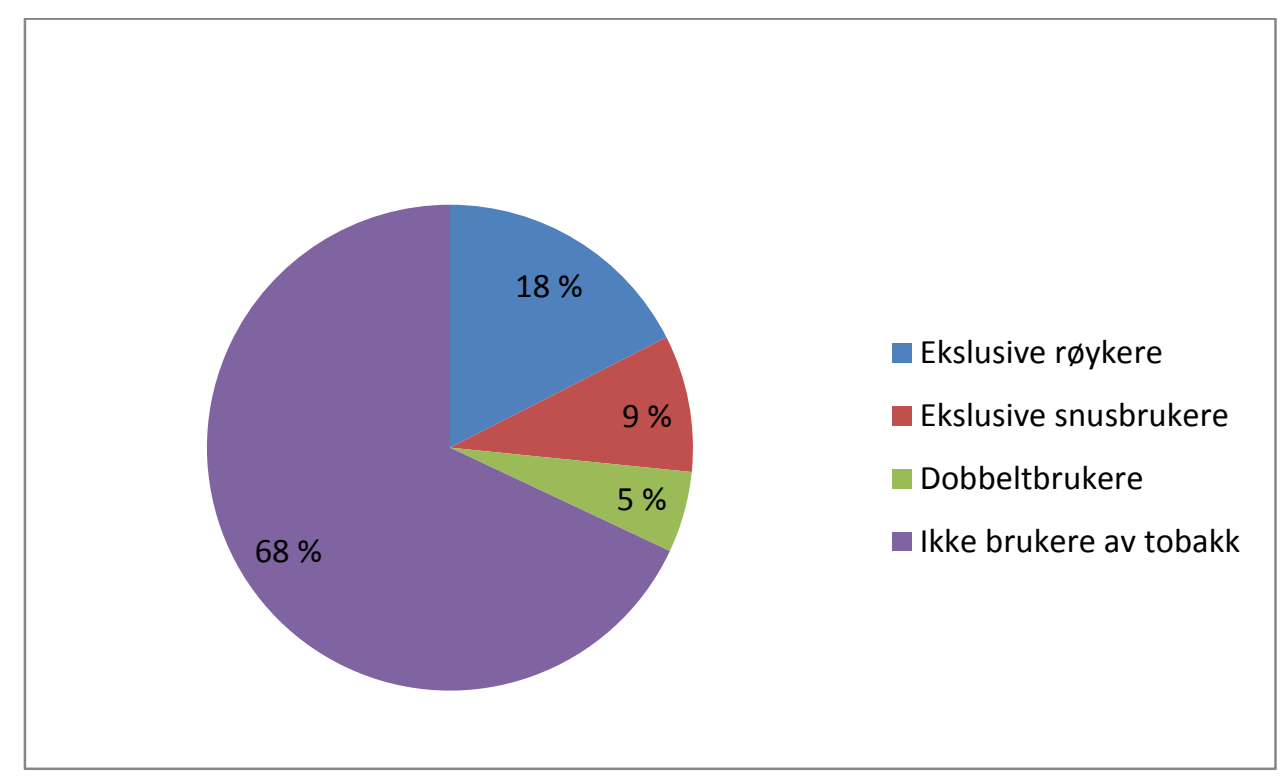

Tabell 2.1 Røykestatus blant snusbrukere.

\begin{tabular}{|l|c|}
\hline & Bruk av snus daglig eller av og til \\
\hline Røyker daglig & 12,4 \\
\hline Røyker av og til & 24,9 \\
\hline Tidligere røyker & 46,0 \\
\hline Har aldri røykt & 16,7 \\
\hline & $100 \%$ \\
\hline Totalt $(\mathrm{N})$ & $\mathrm{N}=282$ \\
\hline
\end{tabular}


Tabell 2.2 Bruk av snus blant røykere.

\begin{tabular}{|l|c|}
\hline & Røyker daglig eller av og til \\
\hline Snus daglig & 15,1 \\
\hline Snus av og til & 8,4 \\
\hline Tidligere brukt snus & 19,8 \\
\hline Aldri brukt snus & 56,7 \\
\hline & $100 \%$ \\
\hline Totalt $(\mathrm{N})$ & $\mathrm{N}=446$ \\
\hline
\end{tabular}

\section{Passiv røyking}

Holdningene til det å røyke hjemme har endret seg betydelig de siste tretti årene (Helsedirektoratet 2013). SIRUS 2012 viser at $86 \%$ av respondentene oppga at det aldri røykes inne i respondentens hjem, mens $7 \%$ oppga at det røykes innendørs hver dag. For respondenter med hjemmeboende barn under 6 år oppga så å si ingen (under 1 prosent) at det røykes innendørs, men i så tilfelle at dette skjer sjeldnere enn månedlig. I husstander med barn i alderen 6-18 år oppga noen flere at det røykes innendørs. Her rapporterte om lag $2 \%$ at det ble røykt daglig og om lag $1 \%$ at det ble røykt sjeldnere enn månedlig.

Innendørs røyking (daglig eller ukentlig) på hjemmearenaen ble oftere rapportert av daglig røykere (35\%) og av-og-til-røykere (9\%) enn av ikke røykere (3\%) (Figur 2.11). Det var likevel $56 \%$ av dagligrøykerne som svarte at innendørs røyking aldri skjedde hjemme. Tobakksbruksundersøkelsen viser at holdningene til det å røyke hjemme har blitt mer negativt med tiden både blant røykere og ikke-røykere, selv om andelen som er enig i at hjem bør være røykfrie er høyere blant ikke-røykere enn blant røykere (Helsedirektoratet 2013). Av respondenter som oppga at det røykes innendørs hjemme på daglig basis, var det $72 \%$ av disse som selv var røykere. 
Figur 2.11 Andelen av befolkningen 16-79 år som rapporterer om røyking innendørs hjemme siste 12 mnd. i ulike røykestatusgrupper. $\mathrm{N}=1944$

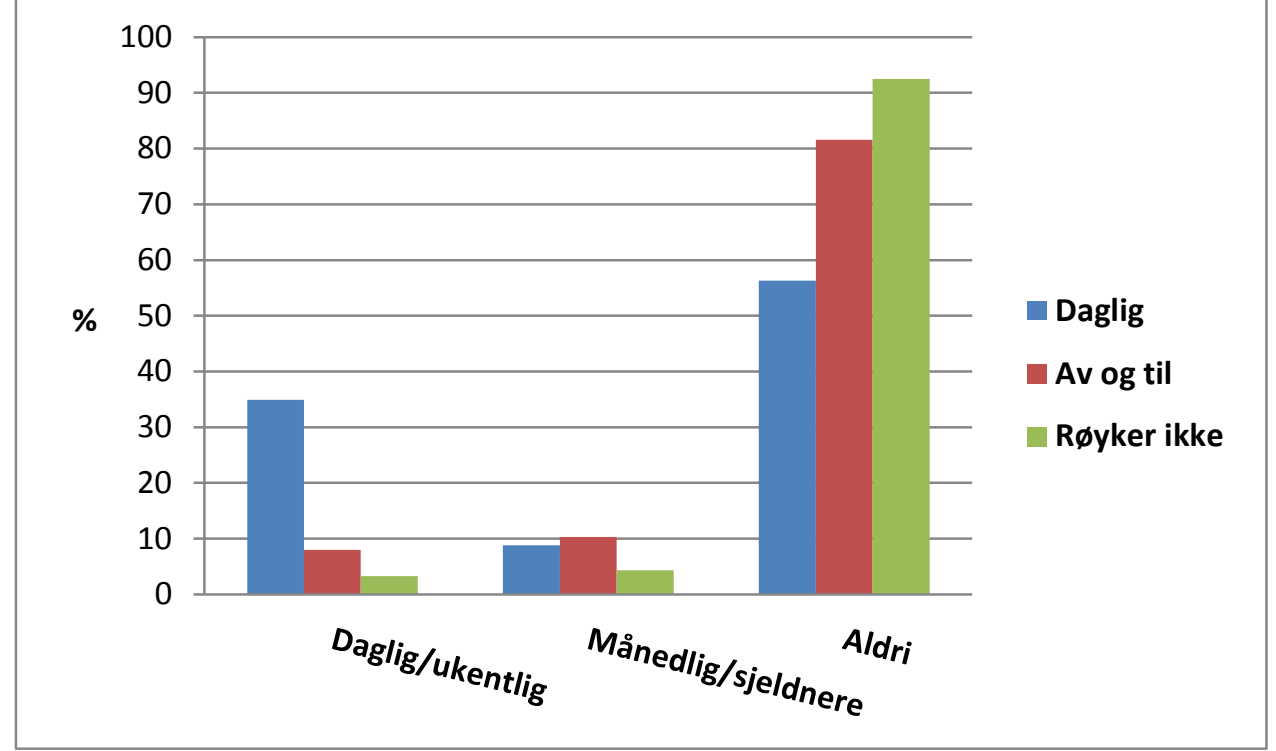

Note: For eksakte prosentandeler se vedleggstabell. 


\section{Bruk av alkohol}

Før vi presenterer resultatene fra SIRUS 2012, vil vi si noe om omsetningen av alkohol i Norge i nyere tid. SSBs salgstall gir et grovt bilde av trender og utviklingstrekk i forbruk, men bildet er ufullstendig fordi alkohol som er kjøpt i tax-free utsalg, i utlandet eller via andre uregistrerte kilder (smugling osv) ikke er inkludert. De aktuelle tallene, som er å finne i Figur 3.1 , viser at den registrerte omsetningen av ren alkohol per innbygger (over 15 år) økte fra 4,55 liter til 6,75 liter per innbygger i perioden 1993 til 2008 - en økning på hele $48 \%$. Dette dreide seg i hovedsak om eskalerende vinsalg, der det også har vært en dreining fra vin på flaske til såkalt pappvin (bag-in-box). Pappvinen ble lansert i 1988, og to år senere sto den for $20 \%$ av det totale vinsalget. I 2012 var andelen $\varnothing \mathrm{kt}$ til $54 \%$ av den totale vinomsetningen.

Som følge av en liten nedgang i omsetningen av brennevin og $\varnothing l$, har den totale omsetningen av alkohol gått noe tilbake etter 2008, og i 2012 var den registrerte omsetningen 6,21 liter ren alkohol per innbygger 15 år og eldre. Dette tilsvarer om lag 69 flasker med vin (12\% alkohol).

Figur 3.1. Omsetning av ren liter alkohol per innbygger 15 år og eldre, 1993-2012

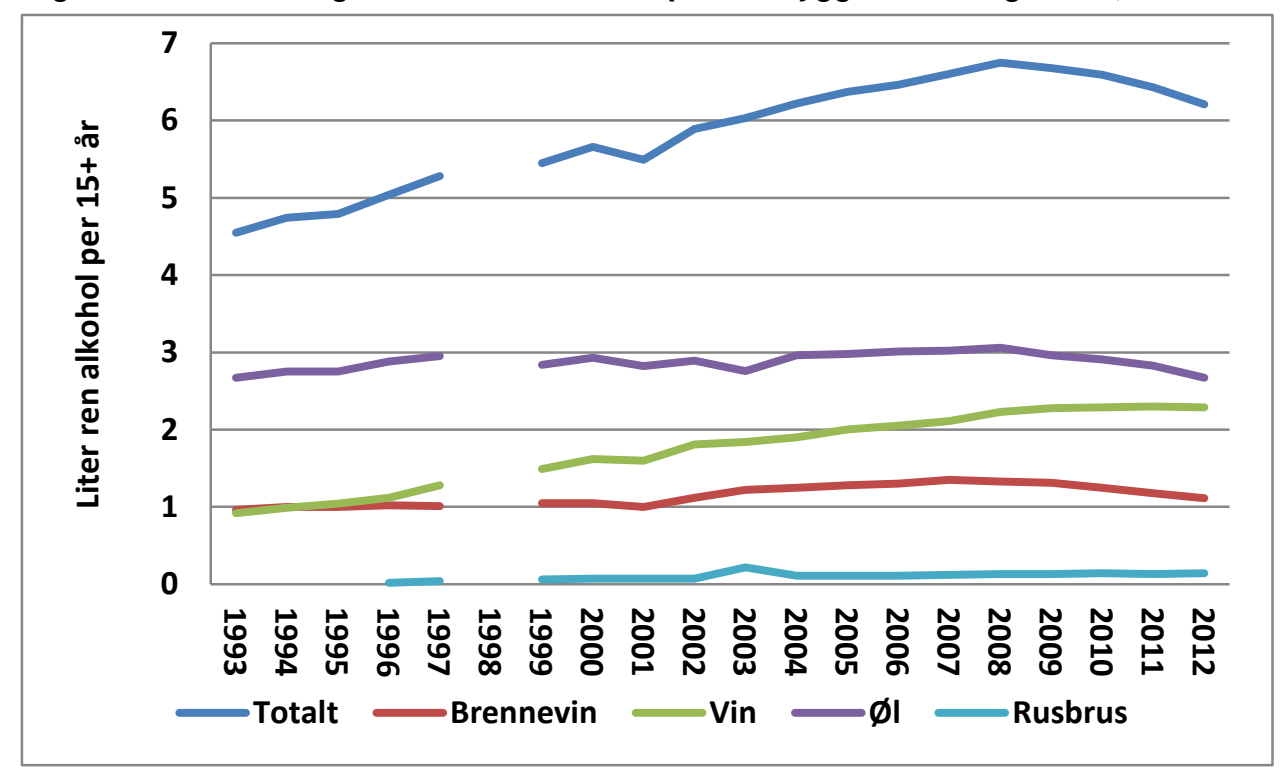

Kilde: SSB (2013). Det foreligger ikke tall for 1998.

Vi vil nå legge fram resultater fra SIRUS 2012 som viser egenrapportert bruk av alkohol. Vi vil se på totalkonsumet og bruk av ulike drikkesorter, forekomst av beruselse, samt i hvilken kontekst man har konsumert alkohol. Resultatene vil bli sammenlignet med tall fra Statistisk sentralbyrås (SSB) «Helse- og levekårsundersøkelser (HLU)” samt SIRUS' egne befolkningsundersøkelser (Bye og Østhus 2011 og 2012). 


\section{Alkoholbruk}

Et solid flertall (88\%) av respondentene i SIRUS 2012-undersøkelsen oppga at de hadde drukket alkohol siste 12 måneder (Tabell 3.1). Andelen var litt lavere blant kvinner (86 \%) enn blant menn (90\%). En liknende kjønnsforskjell ble avdekket i HLU-undersøkelsen fra 2008, der $86 \%$ av kvinnene og $92 \%$ av mennene rapporterte om alkoholbruk siste år (Bye og Østhus, 2011). HLU-undersøkelsene har også avdekket at andelen som har drukket alkohol lå ganske stabilt på ca. 90 \% i aldersgruppen 16-50 år i perioden 1995-2008, men at det har vært en økning fra henholdsvis $81 \%$ til $90 \%$ i alderen 51-65 år og fra $59 \%$ til $78 \%$ i alderen 6679 år (Bye og Østhus, 2012). Vi ser av tabell 2.1 at tallene fra SIRUS 2012 stemmer godt med HLU, og selv om økningen i alkoholbruk har vært størst blant eldre, er det fremdeles flere i de yngre aldersgruppene som drikker alkohol.

Tabell 3.1 Andel som har drukket alkohol siste 12 måneder etter kjønn og alder. (Antall personer i gruppene er angitt i parentes)

\begin{tabular}{|l|c|c|c|c|c|c|c|c|}
\hline \multirow{2}{*}{ Totalt } & \multicolumn{2}{|c|}{ Kjønn } & \multicolumn{6}{c|}{ Alder } \\
\cline { 2 - 10 } & K & M & $\mathbf{1 6 - 2 4}$ & $\mathbf{2 5 - 3 4}$ & $\mathbf{3 5 - 4 4}$ & $\mathbf{4 5 - 5 4}$ & $\mathbf{5 5 - 6 4}$ & $\mathbf{6 5 - 7 9}$ \\
\hline $88 \%$ & $86 \%$ & $90 \%$ & $87 \%$ & $92 \%$ & $90 \%$ & $89 \%$ & $88 \%$ & $80 \%$ \\
\hline$(1947)$ & $(986)$ & $(961)$ & $(317)$ & $(303)$ & $(401)$ & $(344)$ & $(303)$ & $(279)$ \\
\hline
\end{tabular}

\section{Drikkefrekvens}

Respondentene ble spurt om hvor ofte de hadde drukket alkohol siste 12 måneder. I gjennomsnitt rapporterte menn flere drikkedager (51) enn kvinner (40). Av figur 3.2 ser vi at drøyt fire av ti menn og tre av ti kvinner oppga at de har drukket ukentlig siste 12 måneder, og at svært få hadde drukket 4 dager i uken eller mer. I HLU-unders $\varnothing$ kelsen fra 2008 var andelen menn og kvinner som drakk minst 2 ganger i måneden henholdsvis 72 og 56 \% (Bye og Østhus, 2011). De tilsvarende tallene fra SIRUS 2012 er litt lavere, $64 \%$ for menn og $49 \%$ for kvinner. 
Figur 3.2 Drikkefrekvens siste 12 måneder blant menn og kvinner

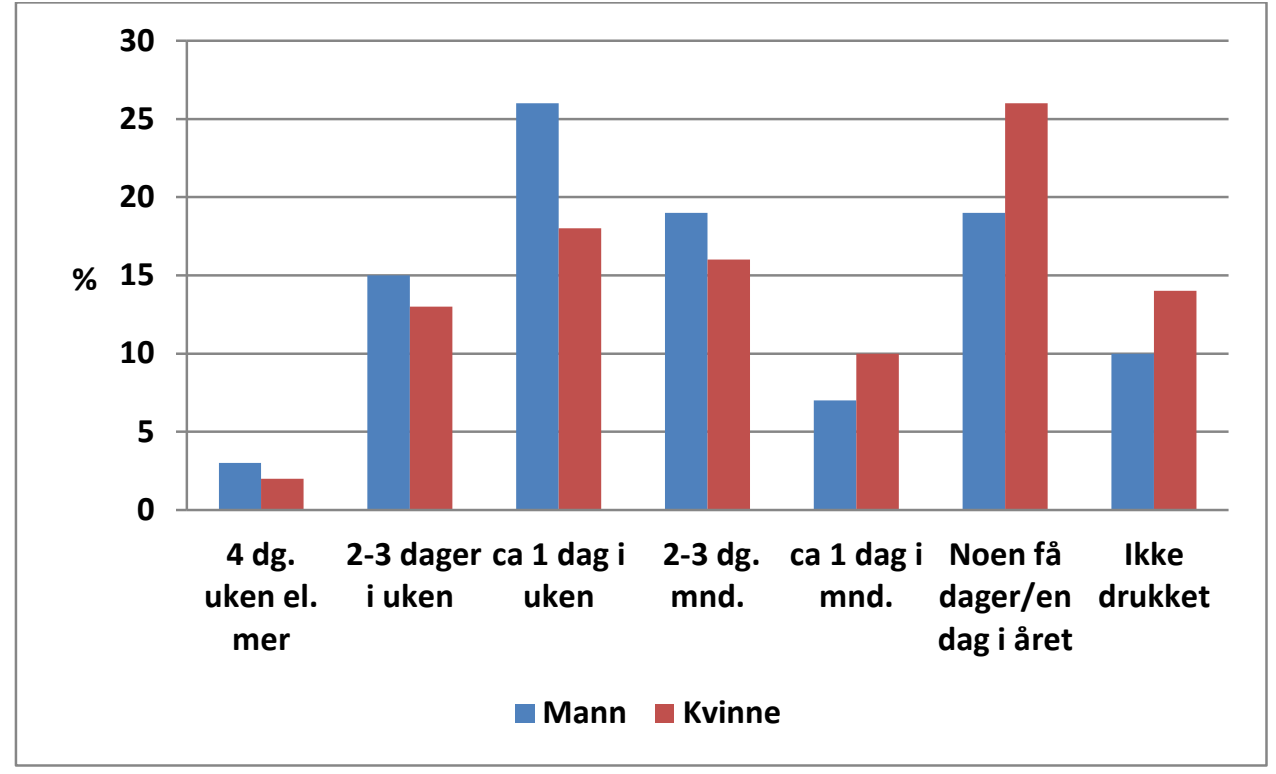

Note: Se vedleggstabell for eksakte prosentandeler.

Av figur 3.3 ser vi at ukentlig drikking er mer utbredt i de eldre enn yngre aldersgruppene, eksempelvis 53 \% i alderen 55-64 år mot 29 \% i alderen 16-24 år. Dette vises også tydelig i tabell 3.2 der vi ser et skille mellom de over og under 45 år. Mens man i alderen 16-44 år har en gjennomsnittlig årsfrekvens som varierer fra 35 til 37 dager, varierer årsgjennomsnittet for aldersgruppene 45-79 år mellom 54 og 60 dager.

Figur 3.3 Drikkefrekvens siste 12 måneder i ulike aldersgrupper

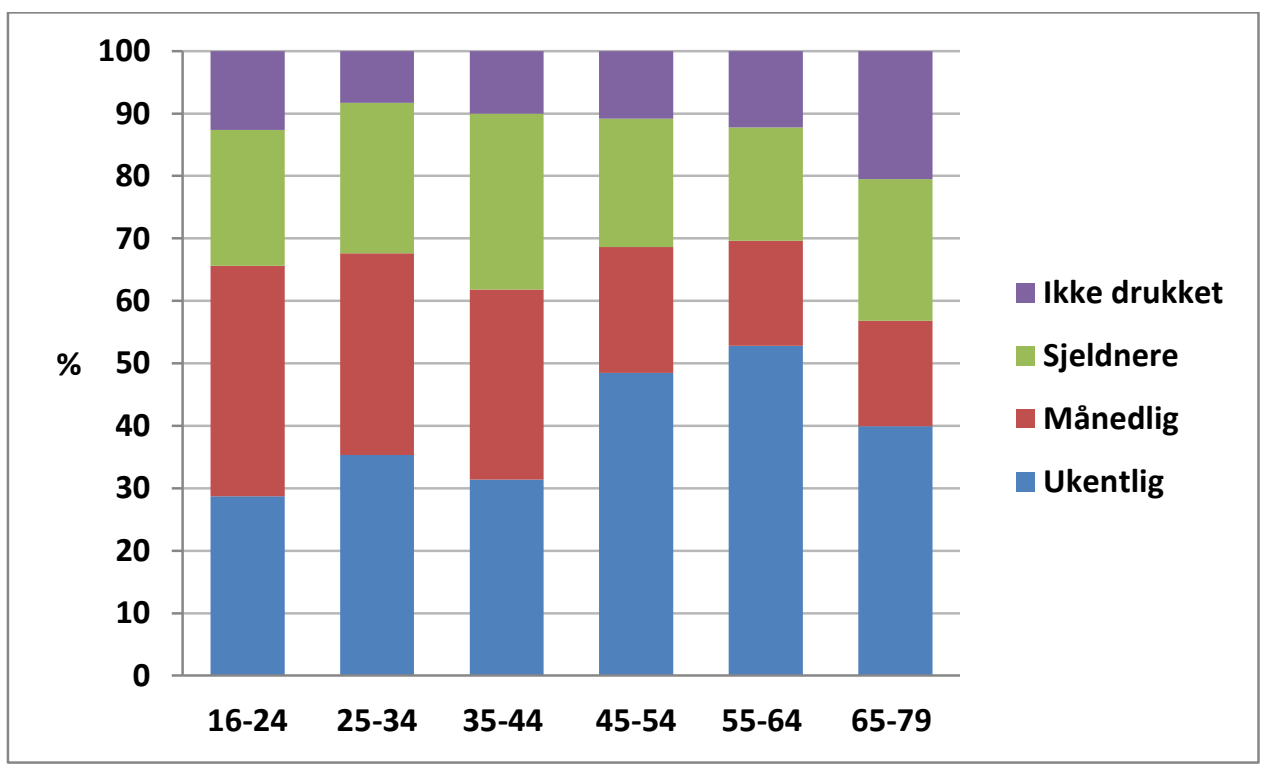

Note: Se vedleggstabell for eksakte prosentandeler. 
Tabell 3.2 Gjennomsnittlig drikkefrekvens siste 12 måneder i ulike aldersgrupper

\begin{tabular}{|l|c|c|c|c|c|c|}
\hline & $\mathbf{1 6 - 2 4}$ år & $\mathbf{2 5 - 3 4}$ år & $\mathbf{3 5 - 4 4}$ år & $\mathbf{4 5 - 5 4}$ år & $\mathbf{5 5 - 6 4}$ år & $\mathbf{6 5 - 7 9}$ år \\
\hline Gjennomsnitt & 35 & 37 & 37 & 54 & 60 & 56 \\
\hline (Standardavvik) & $(51,7)$ & $(46,5)$ & $(53,1)$ & $(64,3)$ & $(69,8)$ & $(83,0)$ \\
\hline $\mathrm{N}$ & 317 & 303 & 401 & 344 & 303 & 279 \\
\hline
\end{tabular}

\section{Beruselse}

Respondentenes beruselsesfrekvens ble kartlagt ved følgende spørsmål: «I løpet av de siste 12 månedene, hvor ofte har du drukket så mye alkohol at du har følt deg tydelig beruset?». Omkring halvparten oppgir å ha vært beruset minst en gang siste 12 måneder, og det dreier seg i hovedsak om noen få dager/en dag i året (figur 3.4). Flere menn enn kvinner oppgir at de har vært beruset siste 12 måneder, $15 \%$ av mennene oppgir at de har vært beruset 1 dag i måneden eller oftere mot $6 \%$ av kvinnene. Vi ser også at mens seks av ti kvinner oppgir at de aldri har vært beruset siste 12 måneder, gjelder dette fire av ti menn. Omregnet til gjennomsnittlig antall ganger beruset siste 12 måneder har menn $(6,1)$ om lag dobbelt så mange beruselsessituasjoner som kvinner $(3,4)$.

Figur 3.4 Beruselsesfrekvens siste 12 måneder blant menn og kvinner (n=1947)

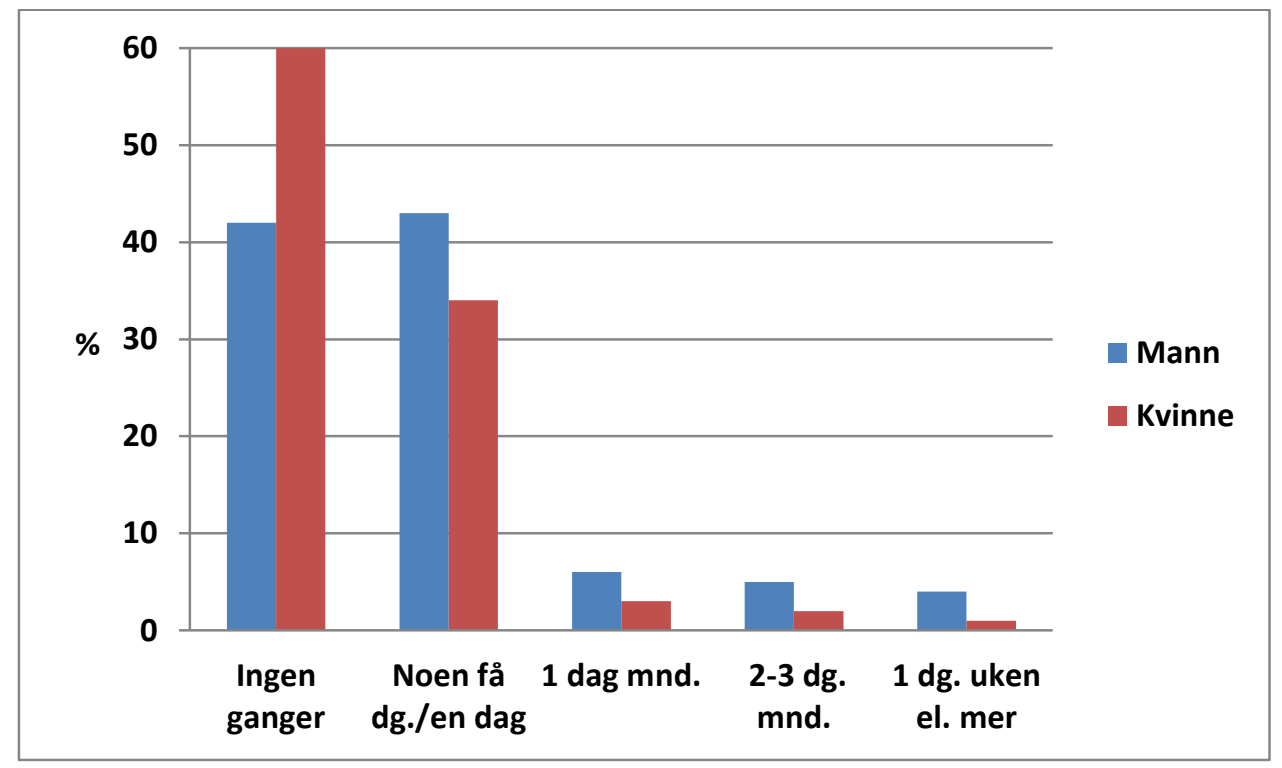

Note: Se vedleggstabell for eksakte prosentandeler.

Av figur 3.5 ser vi at beruselse er vanligst i de yngste aldersgruppene, $7 \%$ i alderen 16-24 år oppga å ha vært beruset ukentlig siste 12 måneder. I den eldste aldersgruppen oppgir hele åtte 
av ti at de ikke har vært beruset. Omregnet til gjennomsnittlig beruselsesfrekvens siste 12 måneder ser vi tydelig hvordan beruselsesfrekvens avtar med $\emptyset$ kende alder (tabell 3.3). Mens gjennomsnittet for aldergruppen 16-24 og 25-34 år er henholdsvis 11,6 og 6,6 ganger i året, er gjennomsnittet 1,7 ganger for 55-64 år og 0,5 ganger for 65-79 år (tabell 2.3).

Figur 3.5 Beruselsesfrekvens siste 12 måneder i ulike aldersgrupper ( $n=1947)$

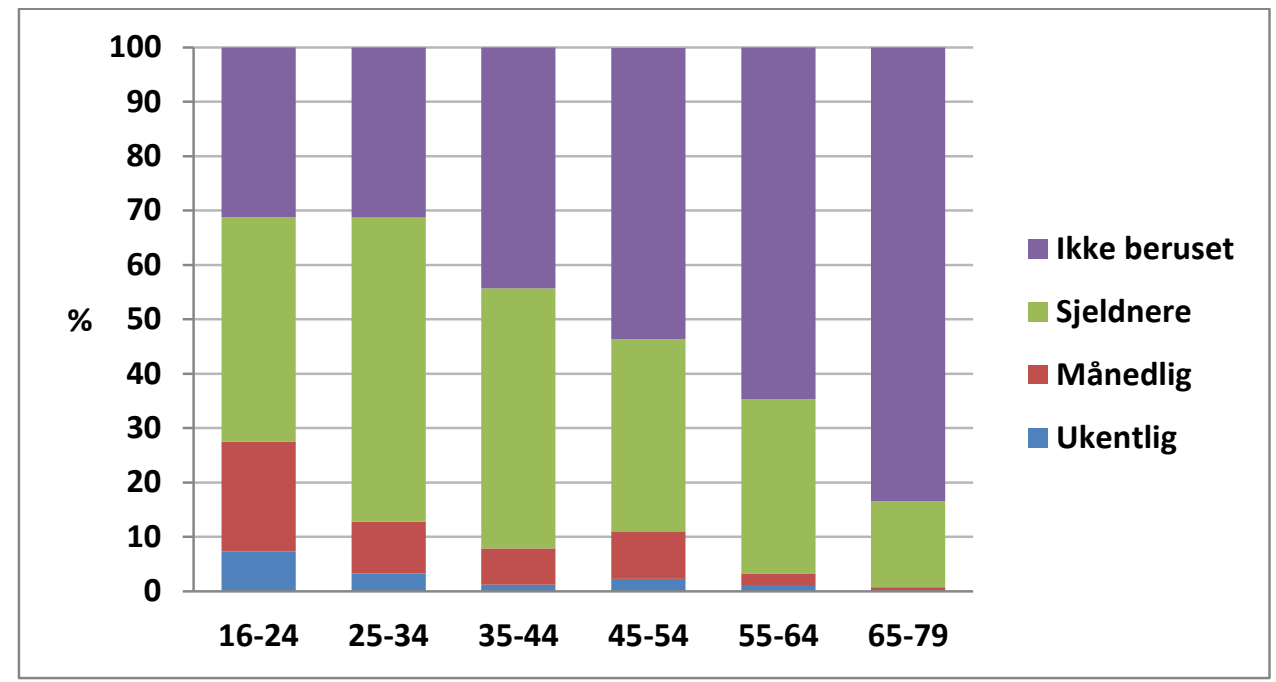

Note: Se vedleggstabell for eksakte prosentandeler.

Tabell 3.3 Gjennomsnittlig beruselsesfrekvens siste 12 måneder i ulike aldersgrupper

\begin{tabular}{|l|c|c|c|c|c|c|}
\hline & $\mathbf{1 6 - 2 4}$ år & $\mathbf{2 5 - 3 4}$ år & $\mathbf{3 5 - 4 4}$ år & $\mathbf{4 5 - 5 4}$ år & $\mathbf{5 5 - 6 4}$ år & $\mathbf{6 5 - 7 9}$ år \\
\hline Gjennomsnitt & 11,6 & 6,6 & 3,2 & 4,9 & 1,7 & 0,5 \\
\hline (Standardavvik) & $(29,2)$ & $(19,5)$ & $(9,8)$ & $(22,6)$ & $(6,0)$ & $(1,5)$ \\
\hline $\mathrm{N}$ & 317 & 304 & 402 & 343 & 303 & 278 \\
\hline
\end{tabular}

I forbindelse med mål på risikofylt alkoholbruk som måles ved hjelp av AUDIT (Alcohol Use Disorder Identification Test, se Babor et al., 2001) ble respondentene spurt: «I løpet av det siste året, hvor ofte har du drukket seks alkoholenheter eller mer ved en og samme anledning?». En alkoholenhet tilsvarer en flaske (0,33 1) med $\varnothing$ l eller cider/rusbrus, ett glass vin (1,5 dl) eller en drink brennevin $(4 \mathrm{cl})$. Omlag seks av ti kvinner og fire av ti menn oppga at de ikke har drukket 6+ enheter ved en og samme anledning siste år (figur 3.6). Det er flere menn enn kvinner som oppga å ha drukket $6+$ enheter ved samme anledning, $23 \%$ menn oppga at de hadde gjort dette månedlig eller oftere, mens tallet for kvinner var $12 \%$. Her må en også ta i betraktning at de fleste kvinner tåler mindre alkohol enn menn. 
Figur 3.6 Andel av befolkningen 16-79 år som har drukket 6 enheter alkohol eller mer ved en og samme anledning siste 12 måneder. Kvinner og menn.

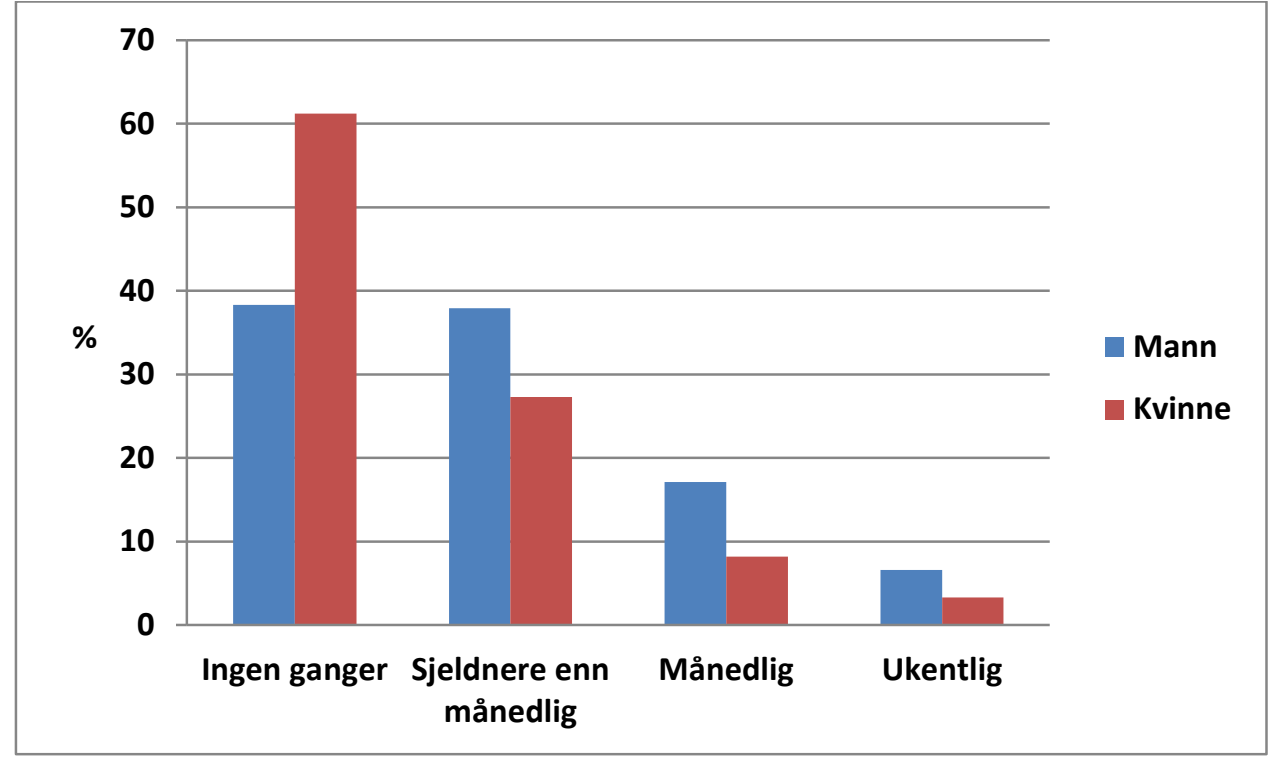

Note: Se vedleggstabell for eksakte prosentandeler.

Også for alder får vi samme mønster som for beruselse, andelen som har drukket 6+ enheter ved samme anledning månedlig/ukentlig faller ved økende alder (figur 3.7). I aldersgruppen 16-24 år oppga $10 \%$ å ha drukket $6+$ enheter ukentlig, mot $2.4 \%$ i den eldste aldersgruppen. Disse resultatene er i samsvar med HLU 2008, der $30 \%$ av respondentene under 30 år oppga at de to ganger i måneden eller oftere drakk seks alkoholenheter eller mer per gang, en andel som var nesten fire ganger så høy som blant personer over 50 år (8 \%) (Bye og Østhus 2011).

Figur 3.7 Andel av befolkningen 16-79 år som har drukket 6 enheter alkohol eller mer ved en og samme anledning siste 12 måneder. Alder

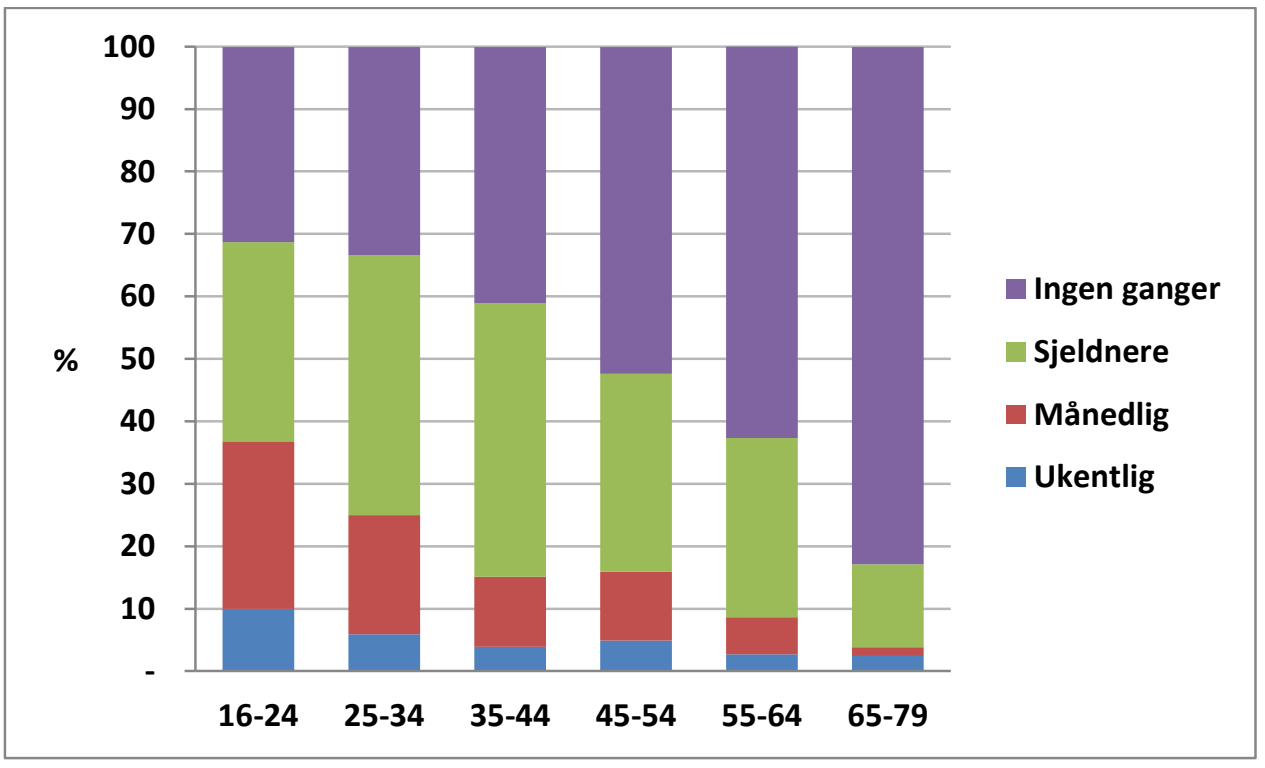

Note: Se vedleggstabell for eksakte prosentandeler. 


\section{Drukket på serveringssted}

Respondentene ble også spurt om hvor ofte de hadde drukket alkohol på et serveringssted (restaurant, kafé, bar, pub, nattklubb o.l.) siste 12 måneder. Omlag syv av ti oppgir å ha gjort dette minst en gang siste 12 måneder, og vi ser at menn oppgir å være oftere på serveringssted enn kvinner (figur 3.8). Henholdsvis $24 \%$ menn og $14 \%$ kvinner oppgir å ha drukket på serveringssted en dag i måneden eller oftere. Omregnet til gjennomsnittlig frekvens per år har menn vært på serveringssted 9.7 ganger mot kvinners 6.5 .

Figur 3.8 Frekvens for bruk av alkohol på serveringsteder siste 12 mnd. blant kvinner og menn

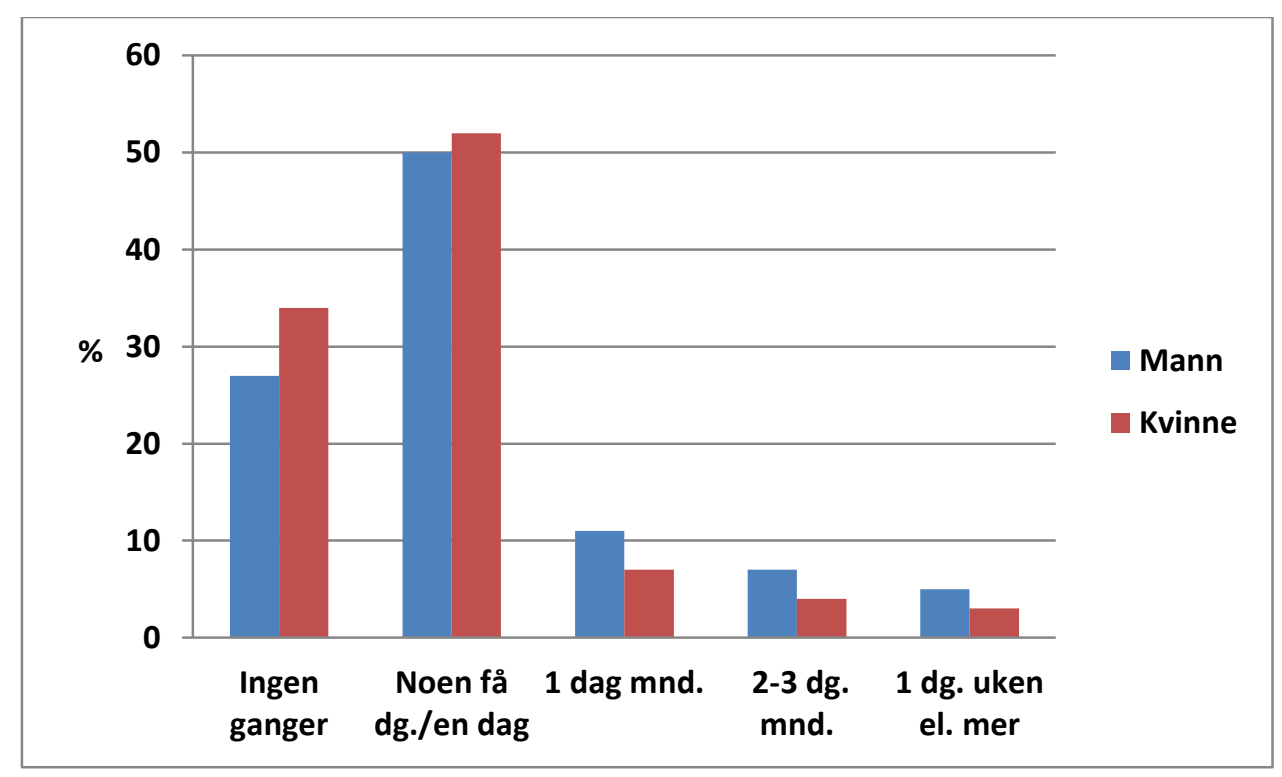

Note: Se vedleggstabell for eksakte prosentandeler.

Av figur 3.9 ser vi at det er de yngste aldersgruppene som oftest har vært på serveringssted, og at halvparten i den eldste aldersgruppen oppgir at de ikke har drukket på serveringssted siste 12 måneder. Av tabell 3.4 ser vi tydelig at det er de yngste aldersgruppene som oftest oppgir å ha drukket på serveringssteder, gjennomsnittlig årsfrekvens for alderen 16-24 år er 15,1 mot 3,7 i aldersgruppen 65-79 år. 
Figur 3.9 Frekvens for bruk av alkohol på serveringssteder siste 12 mnd. I ulike aldersgrupper.

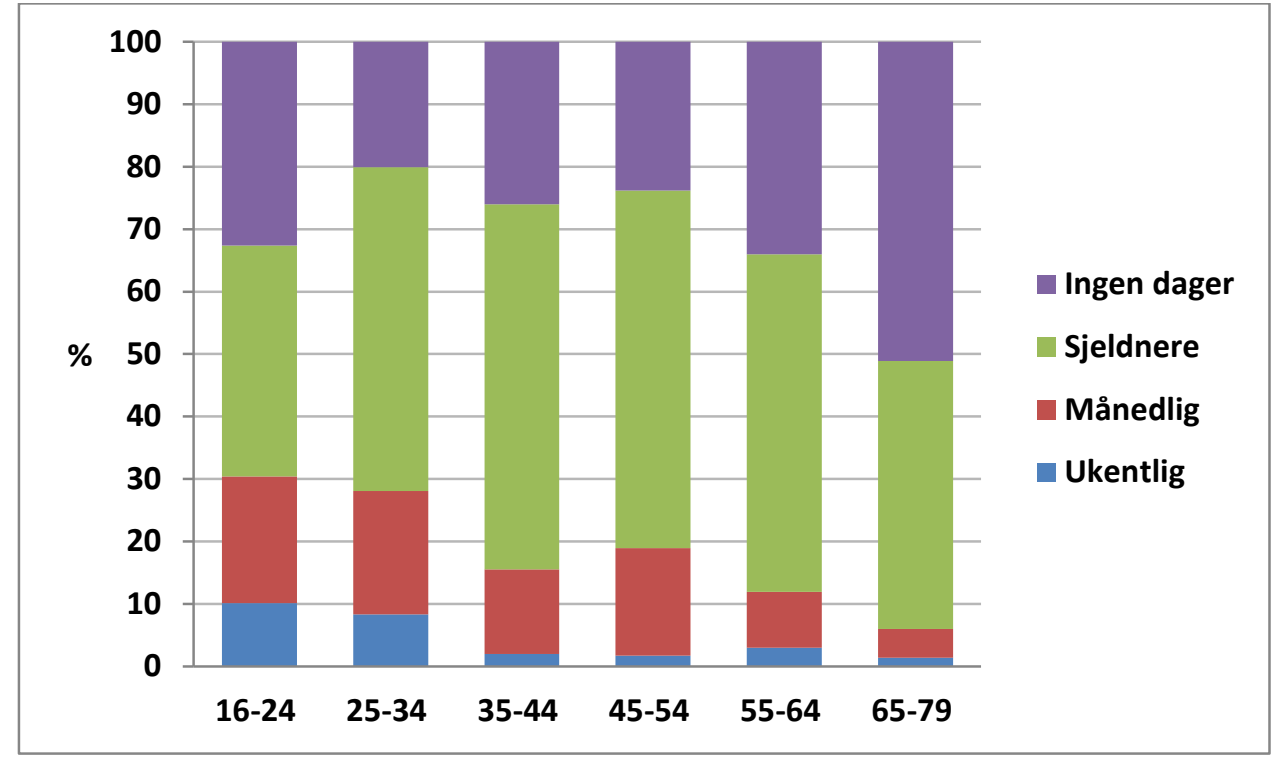

Note: Se vedleggstabell for eksakte prosentandeler.

Tabell 3.4 Gjennomsnittlig frekvens for bruk av alkohol på serveringssteder siste 12 mnd. I ulike aldersgrupper

\begin{tabular}{|l|c|c|c|c|c|c|}
\hline & $\mathbf{1 6 - 2 4}$ år & $\mathbf{2 5 - 3 4}$ år & $\mathbf{3 5 - 4 4}$ år & $\mathbf{4 5 - 5 4}$ år & $\mathbf{5 5 - 6 4}$ år & $\mathbf{6 5 - 7 9}$ år \\
\hline Gjennomsnitt & 15,1 & 11,4 & 5,5 & 5,7 & 7,7 & 3,7 \\
\hline (Standardavvik) & $(36,4)$ & $(20,6)$ & $(11,1)$ & $(11,0)$ & $(35,7)$ & $(14,1)$ \\
\hline $\mathrm{N}$ & 317 & 304 & 400 & 344 & 302 & 279 \\
\hline
\end{tabular}




\section{Ulike drikkesorter}

Respondentene ble også spurt om bruk av alkohol siste 4 uker, og $71 \%$ oppga at de hadde drukket en eller flere alkoholsorter siste 4 uker, og det var flere menn (76\%) enn kvinner (66 $\%)$ som oppga dette.

\section{Drikkesort}

Av figur 4.1 ser vi at det var langt flere menn enn kvinner som oppga å ha drukket øl siste fire uker, hhv 65 og $30 \%$. Det samme gjelder for brennevin, der $39 \%$ av mennene oppga dette mot $18 \%$ av kvinnene. Det var flere kvinner enn menn som oppga å ha drukket vin og rusbrus/cider siste 4 uker, hhv 56 mot $48 \%$ for vin og 11 mot $7 \%$ for rusbrus/cider.

Figur 4.1 Andel kvinner og menn som har drukket de ulike drikkesortene siste 4 uker

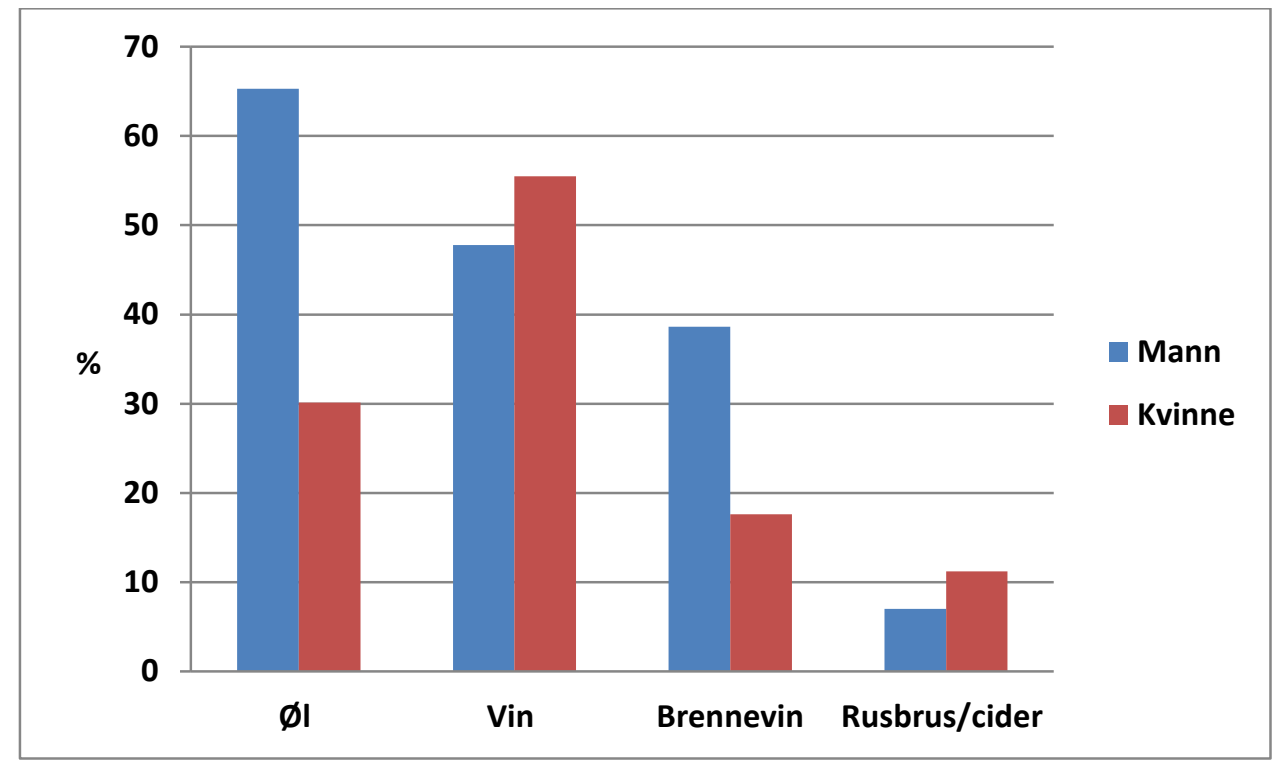

Note: Se vedleggstabell for eksakte prosentandeler.

Av ulike kombinasjoner av drikkevarer siste fire uker var de vanligste:

- Kun vin - $15 \%$.

- $\varnothing 1$ og vin - $15 \%$.

- $\varnothing 1$, vin og brennevin $-13 \%$.

- Kun $\varnothing 1-9 \%$.

- $\varnothing \log$ brennevin $-6 \%$. 
Ser vi på hva som er drukket siste fire uker i de ulike aldersgruppene (figur 4.2), ser vi at rusbrus/cider er noe som først og fremst er blitt drukket i den yngste aldersgruppen (16-24 år). De yngste har også noe oftere drukket brennevin enn eldre respondenter. $\emptyset 1$ og vin er imidlertid det som oftest er drukket i alle aldersgrupper. Mens de yngste oftere hadde drukket $\emptyset l$ enn vin, hadde aldersgruppene 35-44 år og eldre oftere drukket vin enn $\emptyset 1$.

Figur 4.2 Andel av befolkningen 16-79 år som har drukket de ulike drikkesortene siste 4 uker. Aldersgrupper

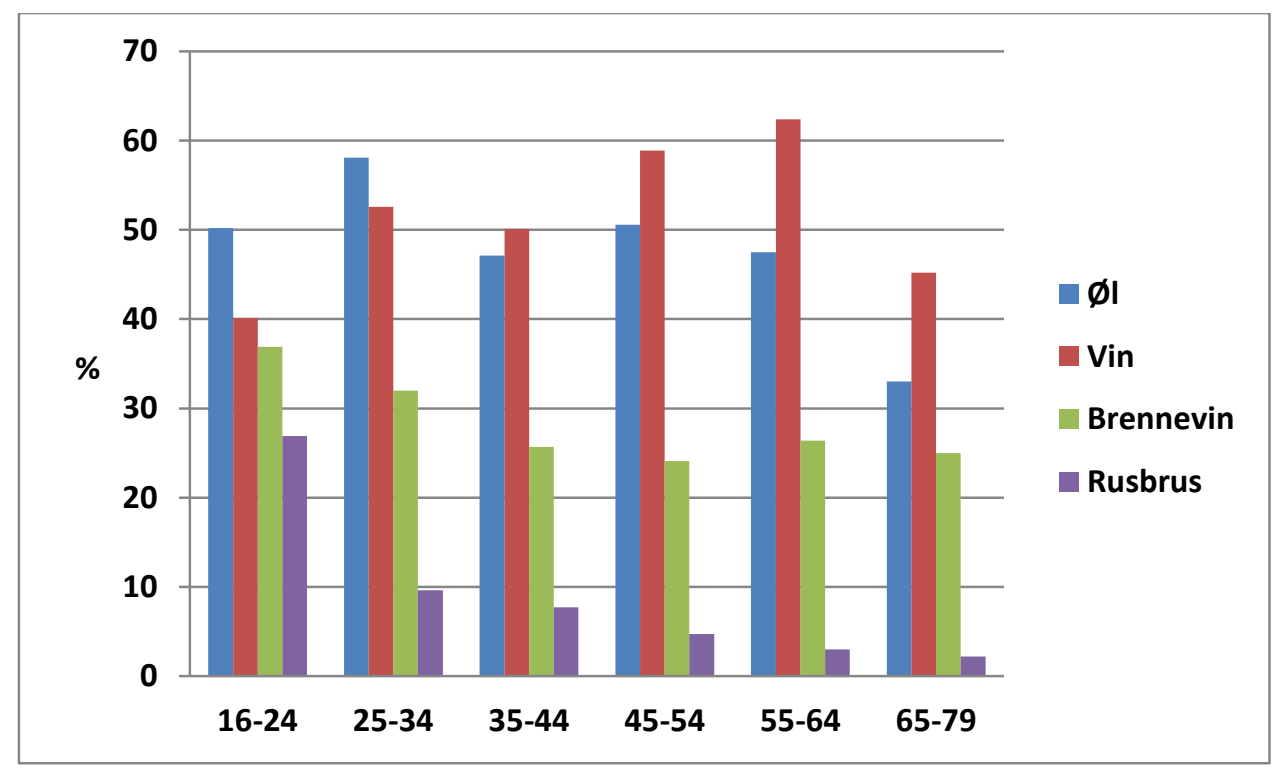

Note: Se vedleggstabell for eksakte prosentandeler.

\section{Bruk av hjemmebrent}

På spørsmål om man i løpet av de siste fire ukene hadde drukket hjemmebrent eller noe som var laget av hjemmebrent, svarte $1,8 \%$ av hele utvalget at de hadde gjort dette. For de som oppga å ha drukket brennevin siste 4 uker $(\mathrm{N}=550)$, var andelen $6 \%$, det var flest menn $(7 \%)$ og respondenter i den yngste aldersgruppen (13\%).

\section{Frekvenser for bruk av de ulike drikkesortene}

Respondentene ble også spurt om hvor ofte de hadde drukket de ulike sortene i løpet av de siste 4 uker. Menn har en høyere gjennomsnittlig frekvens for bruk av $\varnothing 1$ og brennevin, og kvinner har noe høyere gjennomsnittlig frekvens enn menn for vin (tabell 4.1). For alder er 
det mest åpenbare at gjennomsnittsfrekvens for vin er markant større for aldersgruppene 45 år og eldre sammenlignet med de andre.

Tabell 4.1. Gjennomsnittlig frekvens for bruk av ulike drikkesorter siste 4 uker. Kvinner og menn, alder

\begin{tabular}{|l|l|l|c|c|}
\hline & \multicolumn{1}{|l}{} & Vin & Brennevin & Rusbrus \\
\hline Menn & 3.1 & 2.3 & 1.1 & 0.2 \\
\hline Kvinner & 1.0 & 2.7 & 0.4 & 0.3 \\
\hline & & & & \\
\hline $16-24$ & 2.2 & 1.4 & 1.1 & 0.9 \\
\hline $25-34$ & 2.5 & 1.7 & 0.7 & 0.2 \\
\hline $35-44$ & 1.6 & 1.8 & 0.6 & 0.1 \\
\hline $45-54$ & 2.2 & 3.2 & 0.5 & 0.1 \\
\hline $55-64$ & 2.2 & 3.6 & 0.9 & 0.1 \\
\hline $65-79$ & 1.7 & 3.5 & 0.9 & 0.0 \\
\hline
\end{tabular}

Note: Se vedleggstabell for standardavvik.

\section{Beregning av totalkonsum for alkohol}

Med utgangspunkt i respondentenes selvrapporterte konsum siste 4 uker, er det beregnet et gjennomsnittlig totalkonsum for siste 12 måneder. De som oppga å ha drukket de ulike drikkesortene ukentlig ble bedt om å oppgi et gjennomsnittlig antall enheter for de ulike drikkesortene per uke, og de som oppga å ha drukket de ulike sortene sjeldnere enn ukentlig ble bedt om å oppgi totalt antall enheter drukket siste fire uker. Som for andre beregningsmåter er det også fordeler og ulemper ved å estimere totalkonsumet på denne måten. Ved å benytte siste 4 uker istedenfor for eksempel siste 12 måneder vil det være lettere for respondentene å huske hva de faktisk har drukket. På den annen side vil konsumet siste fire uker før surveyen ble gjennomført ikke nødvendigvis være representativt for respondentenes drikkemønster, og i tillegg vil de som drikker, men ikke drakk siste fire uker, ikke bli tatt med i beregningen (dvs. de får verdien 0 ).

Alkoholkonsumet i befolkningen er imidlertid svært skjevfordelt, og vi vet at den tiendedelen i befolkningen som drikker mest, står for omtrent halvparten av det samlete alkoholkonsumet (Stockwell, Zhao, \& Thomas, 2009). Dette gjelder også for utvalget i SIRUS 2012. Tabell 4.2 angir derfor også standardavvik ${ }^{1}$, et $95 \%$ konfidensintervall $^{2}$ samt medianen $^{3}$. Totalkonsumet

\footnotetext{
${ }^{1}$ Standardavviket viser hvor mye en serie med verdier avviker fra seriens gjennomsnitt. Standardavviket sier med andre ord noe om hvor stor spredning (variasjon) det er i datamaterialet.
} 
er oppgitt i liter ren alkohol, og er beregnet med bakgrunn i alle respondentene og ikke kun for de som har drukket siste 12 måneder. Vi ser av tabell 4.2 at det beregnede

gjennomsnittlige totalkonsumet er 3.8 liter ren alkohol. Dette tilsvarer om lag 42 flasker vin eller drøyt 14 flasker brennevin. Vi ser imidlertid at medianen er 1.7, det vil si at halvparten av utvalget har et totalkonsum tilsvarende 1,7 liter ren alkohol eller mindre. Dette kan sees i sammenheng med at en betydelig andel av de eldste (20\% jfr tabell 3.1) ikke hadde drukket alkohol i det hele tatt det siste året.

Videre ser vi at det beregnede alkoholforbruket er dobbelt så høyt for menn (5.2) sammenlignet med kvinner (2.5). Konsumet er størst i den yngste aldersgruppen (5.5), og går så noe ned i det som gjerne betegnes som etableringsfasen. Det laveste konsumet finner vi i den eldste aldersgruppen 65-79 år med 2,6 liter ren alkohol, noe som tilsvarer ca. 29 flasker vin i året.

Tabell 4.2. Gjennomsnitt, standardavvik, $95 \%$ konfidensintervall og median for årlig konsum av ren liter alkohol, for kjønn og alder ( $N=1947)$

\begin{tabular}{|l|c|c|c|c|}
\hline & Gjennomsnitt & Standardavvik & 95\% K.I. & Median \\
\hline Alle & 3.8 & 7.6 & $(3.5-4.2)$ & 1.7 \\
\hline Menn & 5.2 & & & \\
\hline Kvinner & 2.5 & 9.7 & $(4.6-5.8)$ & 2,6 \\
\hline & & 4.3 & $(2.2-2.8)$ & 1.0 \\
\hline $16-24$ & 5.5 & 13.3 & $(4.0-6.9)$ & 2.3 \\
\hline $25-34$ & 4.0 & 6.0 & $(3.3-4.7)$ & 2.3 \\
\hline $35-44$ & 3.1 & 5.3 & $(2.6-3.6)$ & 1.4 \\
\hline $45-54$ & 3.7 & 5.3 & $(3.2-4.3)$ & 1.8 \\
\hline $55-64$ & 4.2 & 8.0 & $(3.3-5.1)$ & 1.8 \\
\hline $65-79$ & 2.6 & 4.4 & $(2.1-3.1)$ & 0.9 \\
\hline
\end{tabular}

${ }^{2}$ Et konfidensintervall angir intervallet som med en spesifisert sannsynlighet inneholder den sanne verdien av variabelen man har målt, og et 95 \%-konfidensintervall inneholder den sanne verdien med en sannsynlighet på 0,95 .

${ }^{3}$ Median et sentralitetsmål som defineres som verdien til tallet som deler et utvalg i to deler slik at hver del har like mange elementer, dvs at halvparten av utvalget her ligger under medianverdien og den andre halvparten over. 
Av tabell 4.3 ser vi at menn drikker atskillig mer $\varnothing 1$ og brennevin enn hva kvinner gjør, menns konsum av $\emptyset$ l er over fire ganger så stort som kvinners, og brennevinkonsumet fire ganger større. Når det gjelder vin og rusbrus er det imidlertid ingen kjønnsforskjeller.

Tabell 4.3. Gjennomsnittlig totalkonsum (liter ren alkohol) for øl, vin og brennevin for alle og fordelt på kjønn ( $N=1947) .95 \%$ konfidensintervall i parentes.

\begin{tabular}{|l|c|c|c|c|}
\hline & $\varnothing \mathbf{I}$ & Vin & Brennevin & Rusbrus/cider \\
\hline Alle & 1.57 & 1.52 & 0.63 & 0.13 \\
\hline & $(1.37-1.75)$ & $(1.36-1.67)$ & $(0.51-0.75)$ & $(0.05-0.21)$ \\
\hline Menn & & & & \\
\hline & $(2.16-2.85)$ & $(1.28-1.73)$ & $(0.78-1.22)$ & $(-0.01-0.30)$ \\
\hline & & & & \\
\hline Kvinner & 0.58 & 1.54 & 0.25 & 0.11 \\
\hline & $(0.45-0.71)$ & $(1.36-1.72)$ & $(0.17-0.32)$ & $(0.08-0.13)$ \\
\hline
\end{tabular}

Når vi ser på hvor mye de ulike drikkesortene utgjør av det totale konsumet for kvinner og menn, ser vi av figur 4.3 at det er klare kjønnsforskjeller. For menn kommer hoveddelen av inntaket fra $\varnothing 1$ (49\%), mens hele $62 \%$ av kvinnenes inntak kommer fra vin.

Figur 4.3 Andel alkohol fra ulike drikkesorter. Kvinner og menn

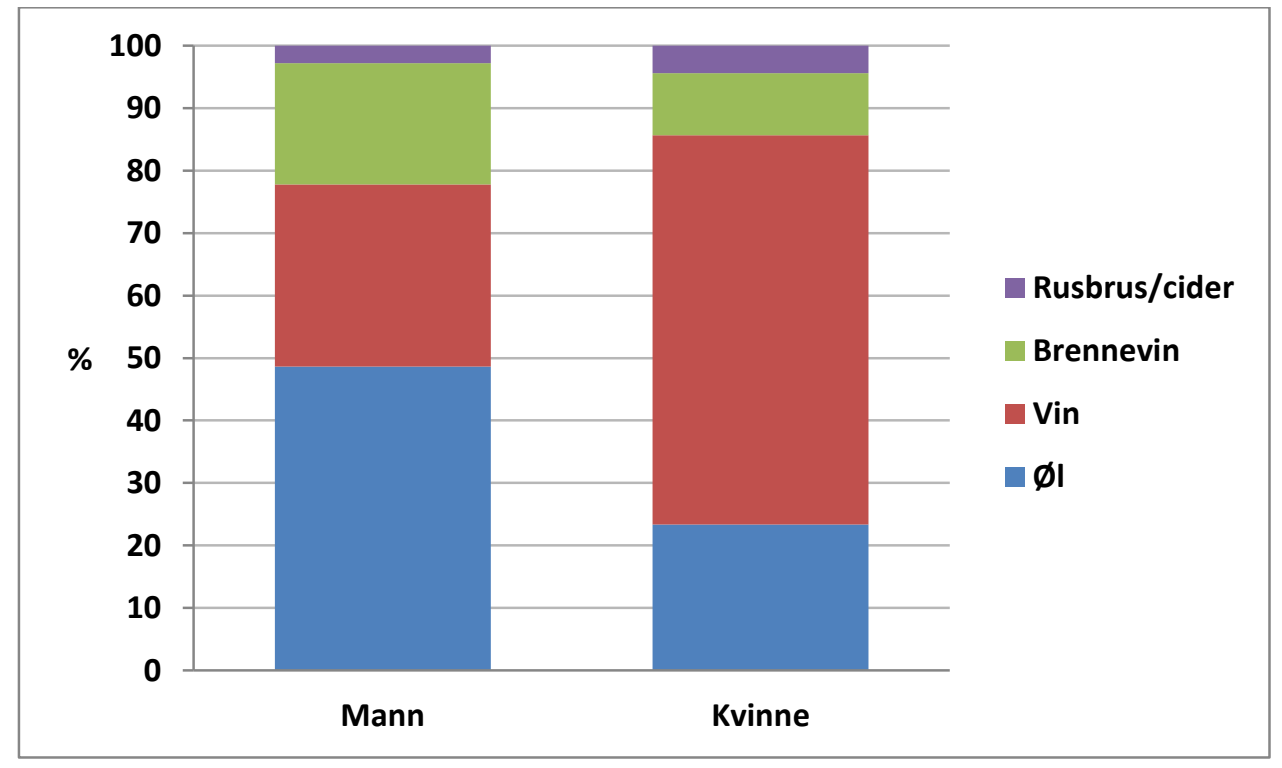

Note: Se vedleggstabell for eksakte prosentandeler. 
Tilsvarende ser vi av figur 4.4 at totalkonsumet blant de yngste hovedsakelig består av $\varnothing 1$, og at vin dominerer i de eldre gruppene. I aldersgruppene 16-24 og 25-34 år kommer henholdsvis 44 og $58 \%$ av totalkonsumet fra $\varnothing 1$, mens $66 \%$ av totalkonsumet i den eldste aldersgruppen kommer fra vin.

Figur 4.4 Andel alkohol fra ulike drikkesorter, ulike aldersgrupper

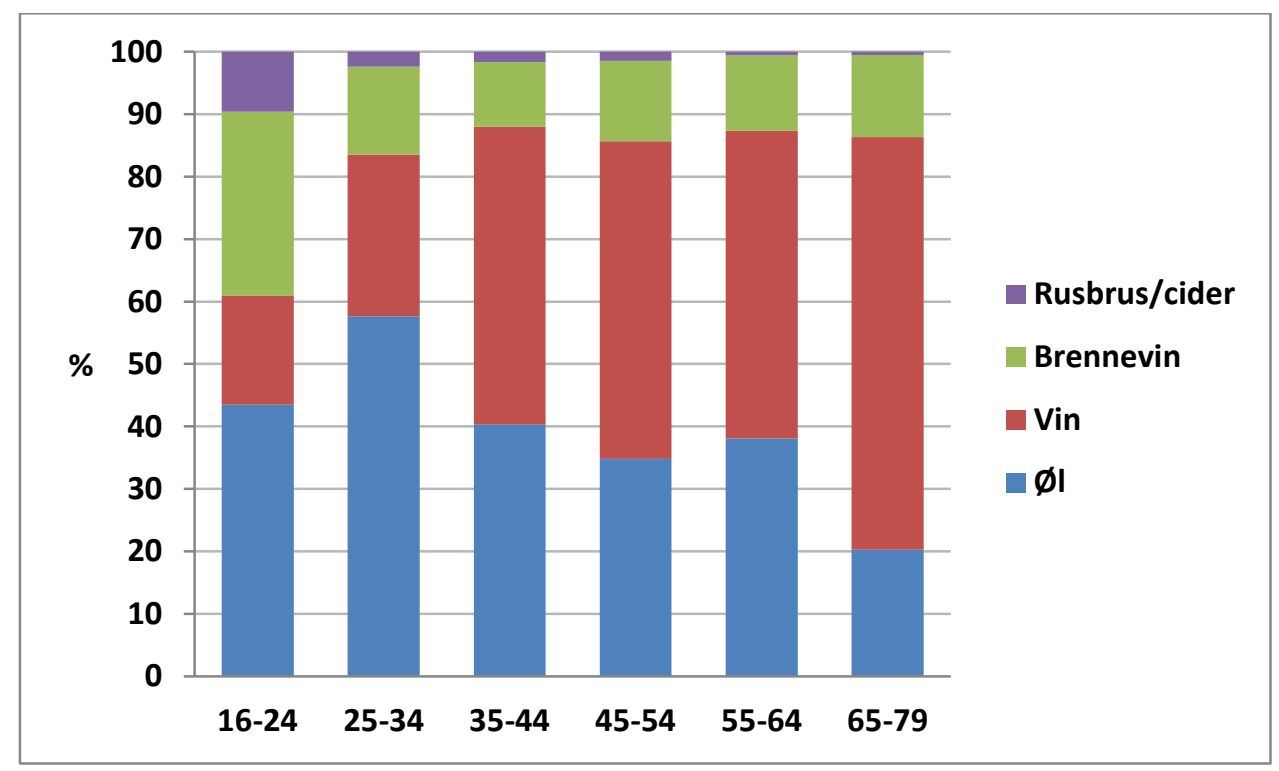

Note: Se vedleggstabell for eksakte prosentandeler.

\section{Avvik fra salgstall}

Vi ser at de estimerte tallene ligger langt under de registrerte salgstallene i figur 3.1, og dette kan ha flere årsaker. Dette med at vi lager et estimat på bakgrunn av konsum siste fire uker er allerede nevnt. En annen ting er at intervjudataene er beheftet med all den usikkerhet som slike undersøkelser alltid er. Når det gjelder data om alkoholforbruk, er det spesielle at usikkerheten som regel går i én retning ved at de som blir intervjuet har en tendens til systematisk å underslå en del av sitt alkoholforbruk. Dette kan skyldes at mange i en intervjusituasjon gjerne vil gjøre et godt inntrykk, og forsøke å framstille seg noe bedre enn det de er. Siden det vanligvis anses for å være bedre å drikke lite alkohol enn mye, vil mange ha en tendens til å slå av på sitt forbruk. Følgene av denne praksisen er at anslaget på alkoholforbruket vi kommer fram til på bakgrunn av intervjudataene, som ideelt sett skulle svare til all den alkoholen som ble drukket i Norge, er mye lavere enn det som faktisk blir drukket. ${ }^{4}$ En annen ting som gjør data basert på intervjuundersøkelser usikre, er at det utvalget

\footnotetext{
${ }^{4}$ Sturla Nordlund (1992): Metoder og metodeproblemer ved estimering av alkoholforbruk. SIFA rapport nr. 3/92, Statens institutt for alkohol- og narkotika, Oslo. 
vi baserer våre svar på, ikke nødvendigvis vil være et representativt utsnitt av den norske befolkningen når det gjelder det fenomenet vi er interessert i. Særlig vil det kunne være en tendens til at de som drikker svært mye, ikke blir tilstrekkelig representert i slike undersøkelser. Det vil også føre til at estimater på alkoholforbruket blir for lave. 


\section{Siste drikkesituasjon}

Respondentene som hadde drukket siste 12 måneder ble også spurt om siste drikkesituasjon, og 1685 av respondentene besvarte disse spørsmålene. Hva en person drakk sist gang han eller hun drakk vil kunne avvike til dels sterkt fra hva en person vanligvis drikker. Det er derfor usikkert hvor representative disse resultatene er.

\section{Hvilken ukedag drikker man?}

Som vi ser av figur 5.1 er det på helgedager de fleste oppgir at de har drukket siste gang. Omlag 7 av 10 drikketilfeller har funnet sted på fredag eller lørdag, med en klar overvekt på lørdag. Det er ikke særlig forskjell mellom menn og kvinner, og heller ikke mellom de ulike aldersgruppene. Det var imidlertid en større andel blant de som var 45 år eller eldre, som oppga søndag som siste gang de drakk, enn hva gjaldt de yngre aldersgruppene.

Figur 5.1 Andel av befolkningen 16-79 år som drakk på ukedager eller helg sist de drakk alkohol. Kvinner og menn. ( $\mathrm{N}=1685)$

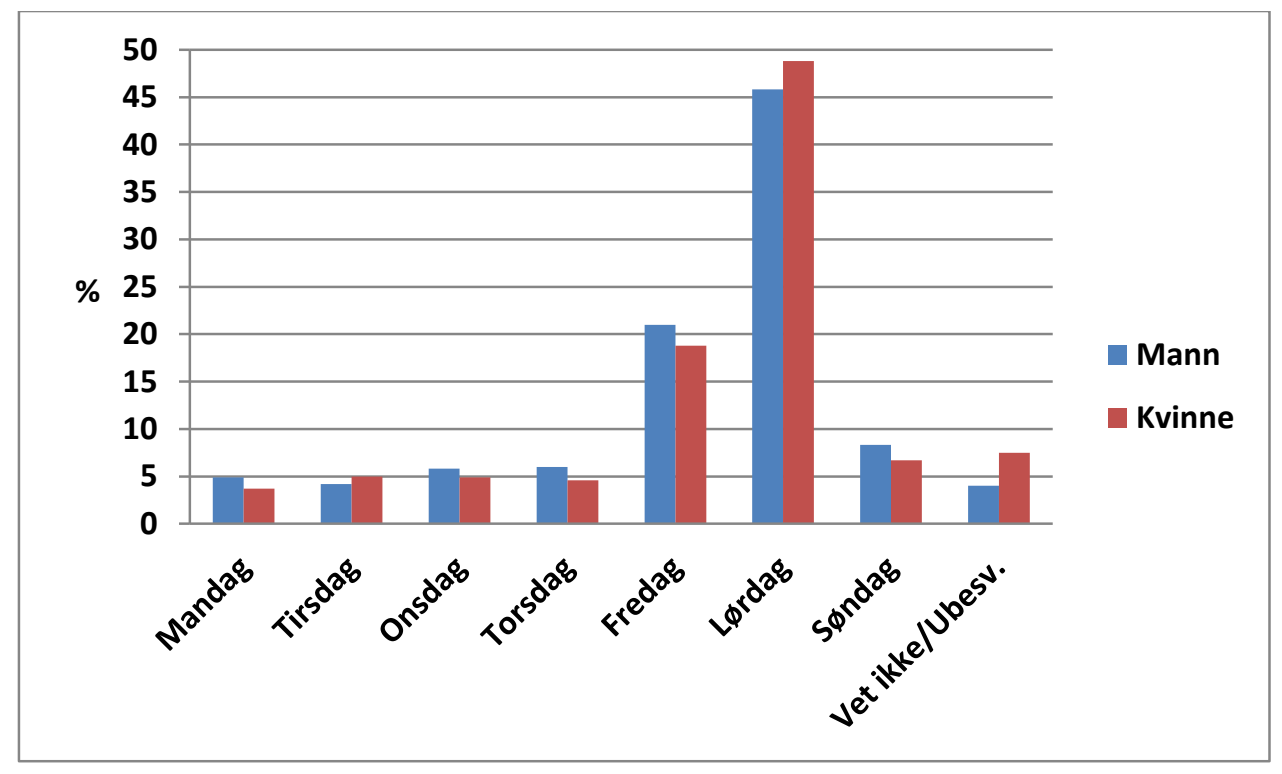

Note: Se vedleggstabell for eksakte prosentandeler.

\section{I forbindelse med måltid?}

Det ble også spurt om hvorvidt sist gang man drakk var i forbindelse med et måltid, noe som gjaldt $62 \%$ (66\% kvinner mot $58 \%$ menn). Andelen som hadde drukket i forbindelse med måltid var også stigende med alder, fire av ti i aldersgruppen 16-24 oppga at siste drikkesituasjon var i forbindelse med måltid, mens det samme gjaldt syv av ti i alderen 45+ år. 


\section{Sted og sosial kontekst}

På spørsmål om hvor man var sist man drakk alkohol (her kunne man angi flere svar), ser vi at både kvinner og menn i all hovedsak har drukket på privat sted (hjemme/hjemme hos andre) (figur 5.2). I overkant av $20 \%$ oppga også at de hadde drukket på offentlig sted sist gang de drakk (restaurant/utested/offentlig område). Det var en større andel blant de yngste enn blant de eldste som hadde drukket på restaurant/offentlig sted sist de drakk, henholdsvis $34 \%$ og $29 \%$ i de to yngste aldersgruppene mot $13 \%$ i den eldste.

Figur 5.2 Hvor man var sist gang man drakk alkohol. Kvinner og menn

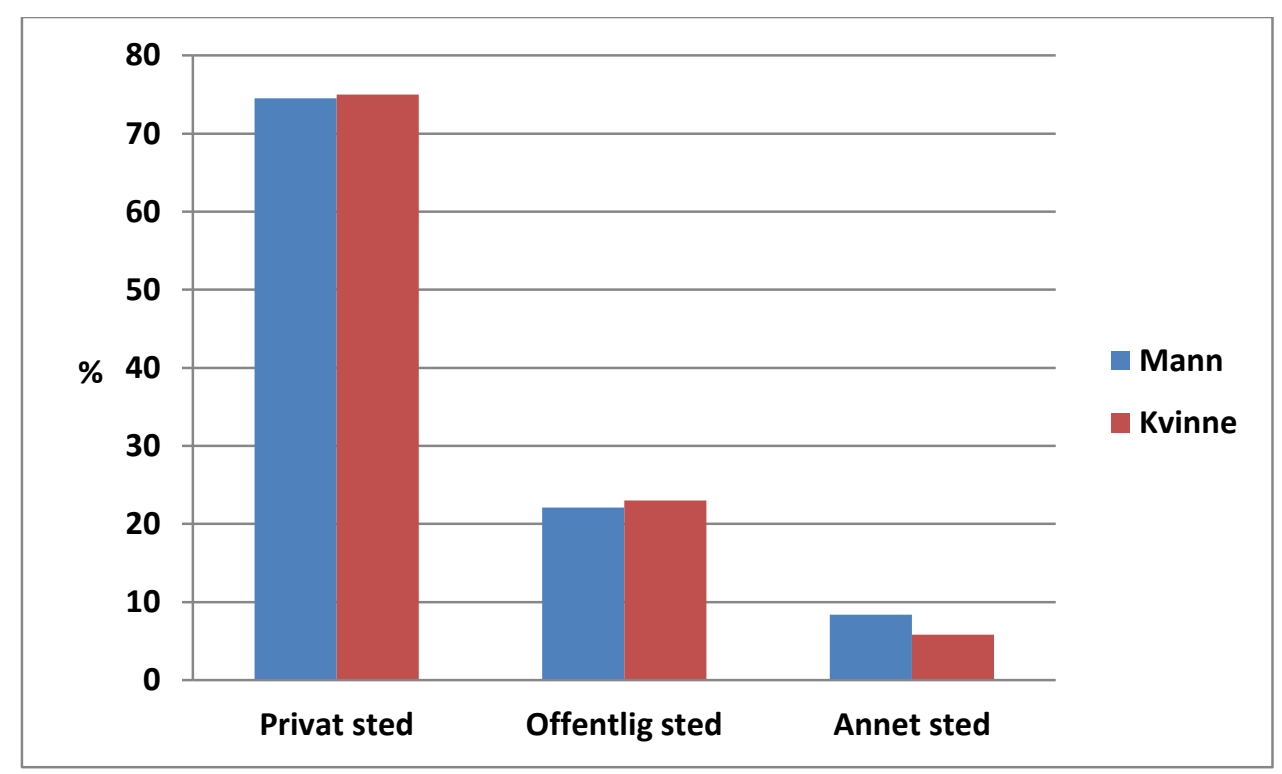

På spørsmål om hvem man eventuelt hadde vært sammen med sist gang en drakk alkohol (også her kunne en angi flere svar), oppga fem av ti at de hadde vært sammen med ektefelle/kjæreste, fire av ti hadde vært sammen med venner, to av ti sammen med andre familiemedlemmer, og en av ti med kolleger/studievenner (Figur 5.3). Det var en større andel kvinner enn menn som hadde drukket med andre familiemedlemmer, og en større andel menn enn kvinner som oppga at de hadde drukket alene. Andelen som oppga å ha drukket med ektefelle/kjæreste eller andre familiemedlemmer $\varnothing$ kte naturlig nok med $\varnothing$ kende alder, mens det å ha drukket med venner/bekjente og kolleger/studievenner var mer vanlig blant de unge. 
Figur 5.3 Andel som har drukket sammen med ektefelle, annen familie, kolleger/studievenner, venner/bekjente eller alene. Kvinner og menn

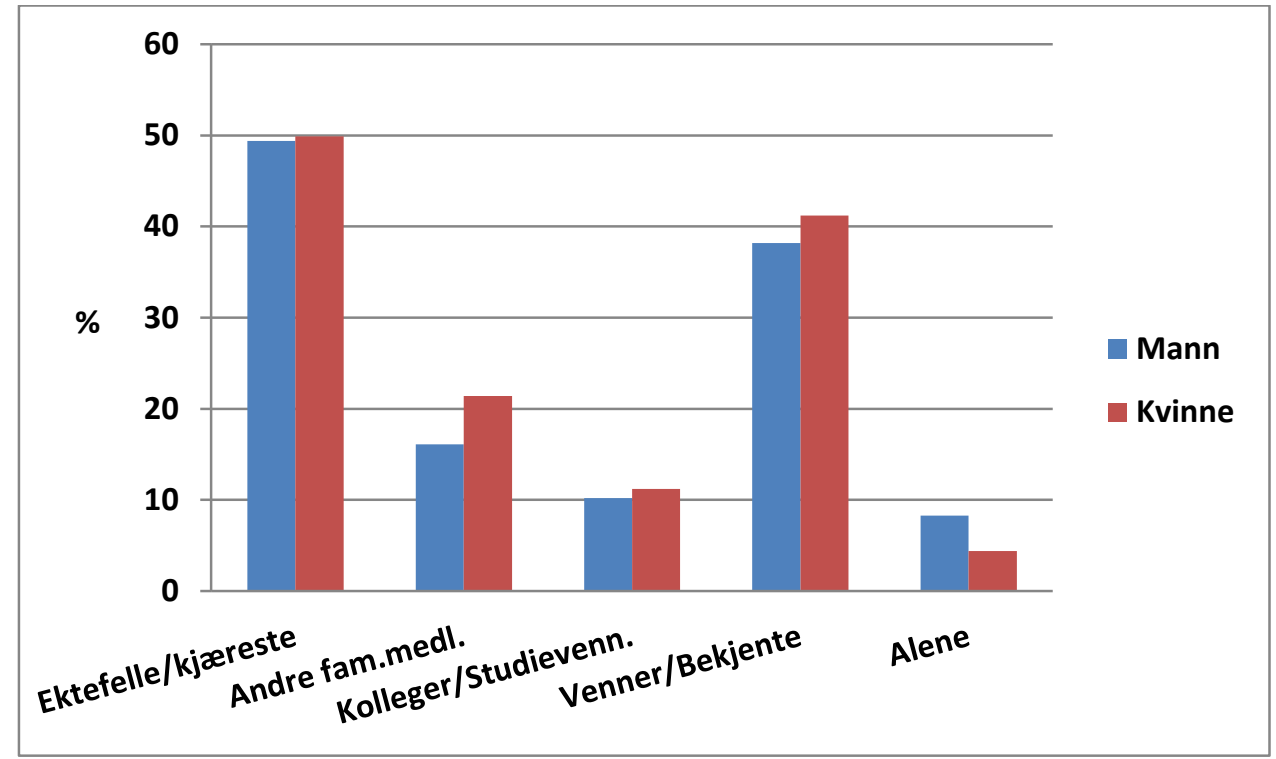

\section{Antall enheter drukket sist gang}

Respondentene ble spurt om hvor mange enheter de hadde drukket av de ulike drikkesortene sist gang de drakk (figur 5.4). Menn oppga å ha drukket flere enheter enn kvinner sist gang de drakk, henholdsvis 5.2 mot kvinners 3.4 (gjennomsnitt). Fordelt på ukedagene ser vi tydelig at menn som har drukket på torsdag, fredag eller lørdag har konsumert langt flere enheter enn menn som har drukket de andre dagene. For kvinner er ikke dette mønsteret like markant.

Figur 5.4 Gjennomsnittlig antall enheter for de ulike drikkesortene sist gang man drakk. Kvinner og menn, ukedag

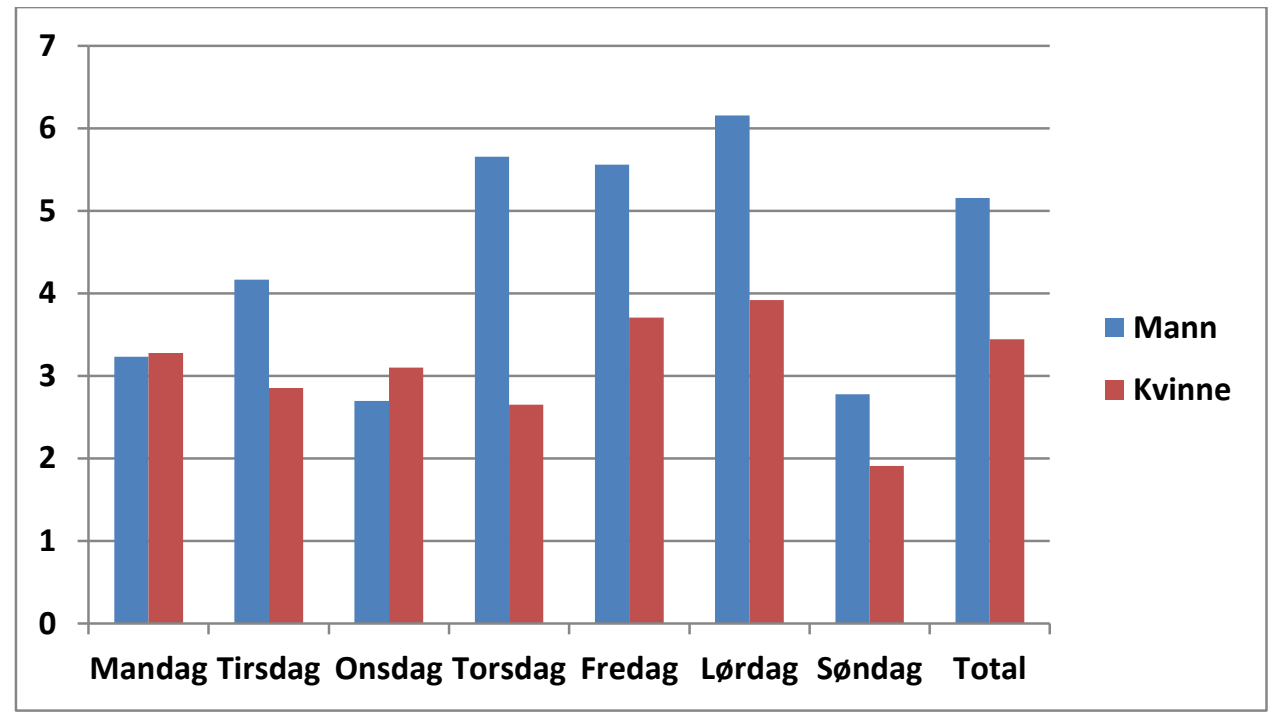




\section{Var man beruset sist gang man drakk?}

Til slutt ble respondentene spurt om grad av beruselse ved spørsmålet "Sist gang du drakk alkohol, følte du deg tydelig beruset, lett beruset eller nesten upåvirket?”. Flere menn enn kvinner oppga at de hadde følte seg tydelig/lett beruset, henholdsvis 37 mot $30 \%$ (Figur 5.5). Andelen som hadde følt seg tydelig/lett beruset sank med økende alder, eksempelvis oppga 20 \% i alderen 16-24 år at de hadde vært tydelig beruset sist gang de drakk, mens så godt som ingen i de eldste aldersgruppene oppga dette. Det samme gjaldt for det å ha følt seg lett beruset, fire av ti i alderen 16-24 år oppga å ha følt seg lettere beruset mot en av ti i alderen 65-79 år. Av figur 5.6 ser vi også at de som har drukket på fredager og lørdager, og som da også har konsumert flest enheter, jfr. Figur 5.4, i større grad oppgir at de har følt seg tydelig/lett beruset.

Figur 5.5 Andel som følte seg tydelig beruset, lett beruset eller nesten upåvirket sist gang man drakk, for kvinner og menn

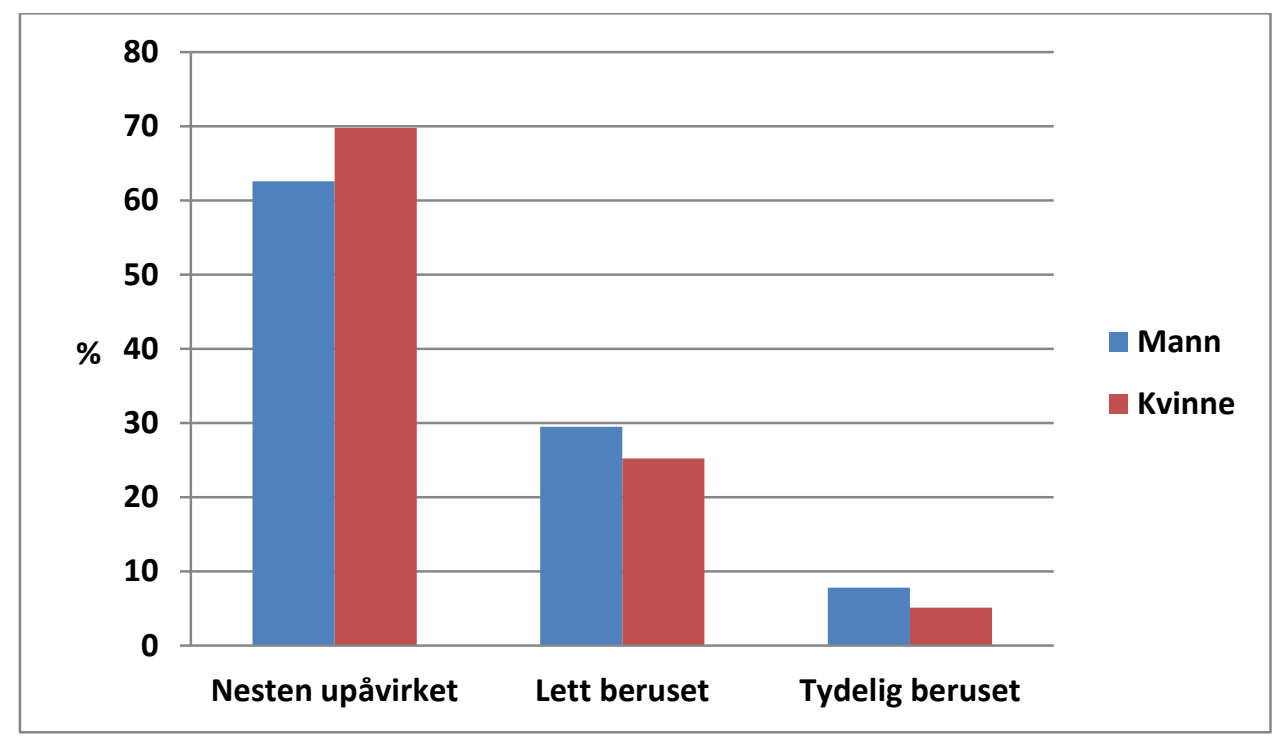


Figur 5.6 Andel som følte seg tydelig beruset, lett beruset eller nesten upåvirket sist gang man drakk. Ukedager

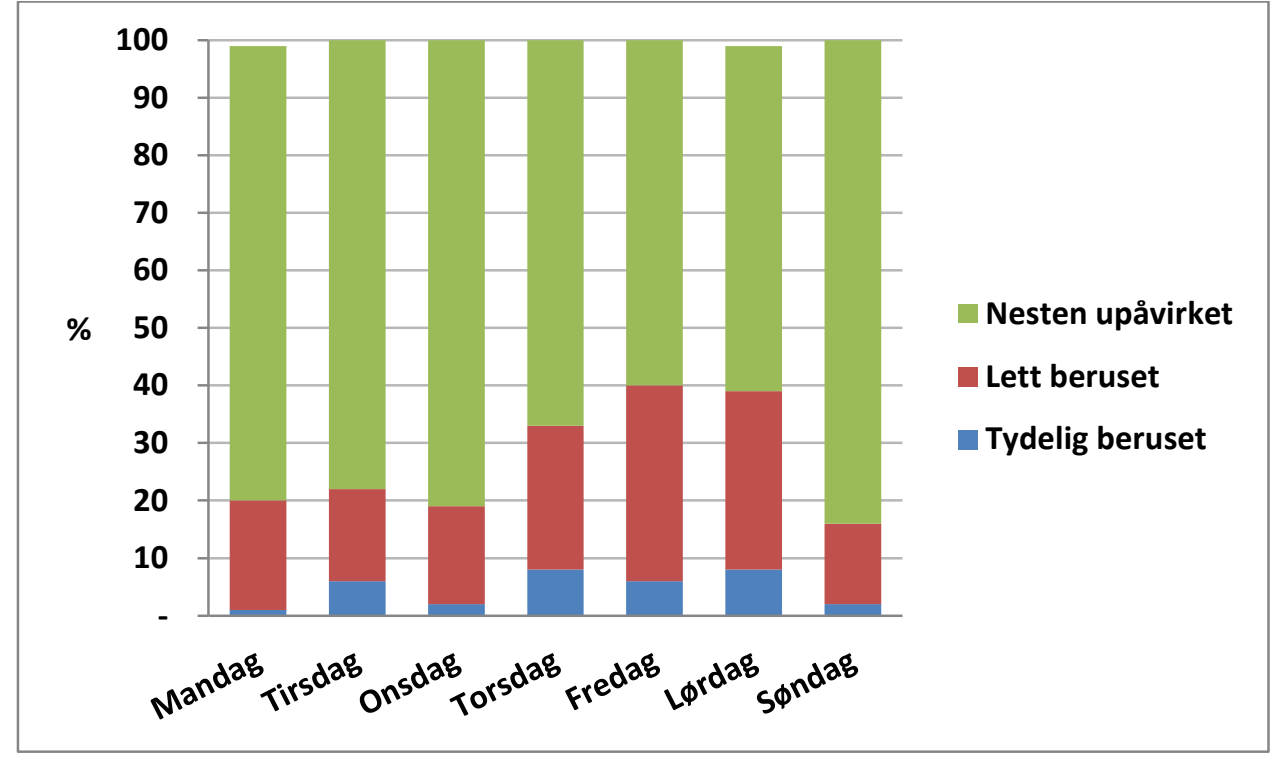




\section{Cannabisbruk}

Cannabisplantene er det mest utbredte ulovlige rusmiddel i den norske befolkning, så vel som i resten av verden. Samlebetegnelsen cannabis dekker i denne unders $\emptyset$ kelsen ulike varianter av bearbeiding av marihuanaplanten: marihuana (løst eller presset plantemateriale), hasjisj (seige klumper eller brikker hovedsakelig av cannabisharpiks) og cannabisolje (destillert harpiks). Dessuten har det dukket opp nye syntetiske cannabisstoffer som er produsert i laboratorier uten bruk av cannabisplanten (Bachs \& Tuv, 2012). Spørsmålene om bruk av cannabis er bare stilt til aldersgruppen 16-64 år fordi det er svært få som bruker narkotika i høyere aldersgrupper ( $\mathrm{N}=1667)$. Ved en feiltagelse ble spørsmål om andre narkotiske stoffer kun stilt til de som oppga at de hadde brukt cannabis noen gang, slik at for 2012 finnes ikke dekkende informasjon om bruk av stoffer som kokain, amfetamin etc. i befolkningen.

SIRUS har jevnlig gjennomført spørreundersøkelser om cannabisbruk siden 1985. Selv om disse har vært gjennomført på en annen måte enn den siste fra 2012, så er metodene og spørsmålsstillingene såpass nær at det gir mening å sammenligne resultatene (Hordvin, 2005). Bruk av cannabis en eller flere ganger hittil i livet har $\varnothing \mathrm{kt}$ jevnlig helt siden 80 -tallet, se figur 6.1. Dette er naturlig fordi cannabisbruk startet blant ungdom og unge voksne på 1960-tallet, og de fleste av disse har ennå ikke passert 65 år. Stadig nye personer prøver cannabis, og dermed vil andelen som har prøvd stoffet stadig $\varnothing \mathrm{ke}$.

Figur 6.1. Andel av befolkningen 16-64 år som har brukt cannabis noen gang, siste 12 måneder og siste 4 uker. 1985-2012

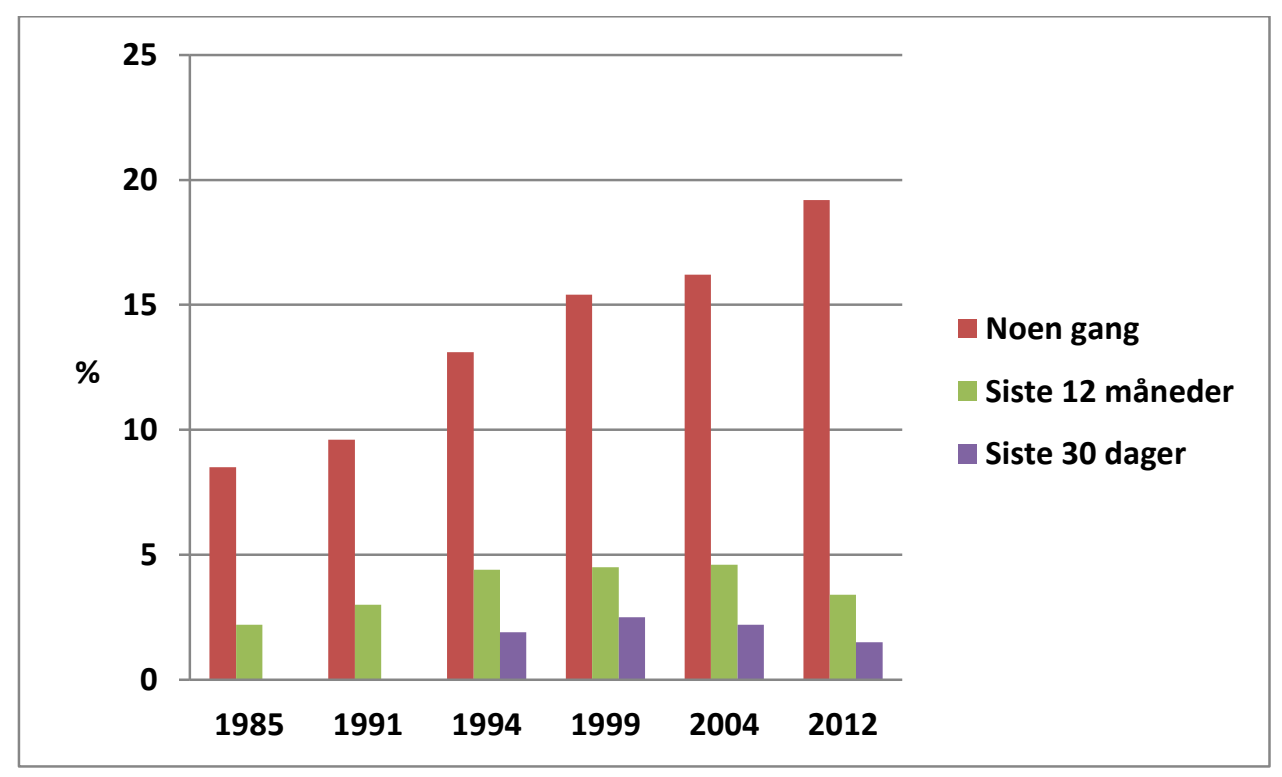

Note: Se vedleggstabell for eksakte prosentandeler.

I 2012 oppga 19,2\% at de hadde brukt cannabis noen gang, mens tilsvarende tall var 8,5\% i 1985. Andelen av befolkningen som har brukt cannabis siste år og siste 30 dager er mye 
lavere enn for noen gangs bruk for alle år, hhv. 3,4 og 1,5\% i 2012. Det kan av figur 6.1 se ut som en mindre andel av befolkningen brukte cannabis siste år og siste 30 dager i 2012 enn i 2004, men forskjellen er ikke større enn at den kan skyldes tilfeldigheter knyttet til at vi viser tall for et utvalg av befolkningen. Cannabisbruk siste 12 måneder og siste 30 dager kan dermed ikke sies å ha endret seg de siste 18 årene.

Det var en større andel menn enn kvinner som hadde brukt cannabis. Dette gjaldt for noen gangs bruk (hhv. 23,4 og 14,7 \%), bruk siste 12 måneder (hhv. 4,9 og $2 \%$ ) og bruk siste 4 uker (hhv. 2,2 og 0,7\%). Se figur 6.2.

Figur 6.2. Andel av befolkningen 16-64 år som har brukt cannabis noen gang, siste 12 måneder og siste 4 uker. Kvinner og menn

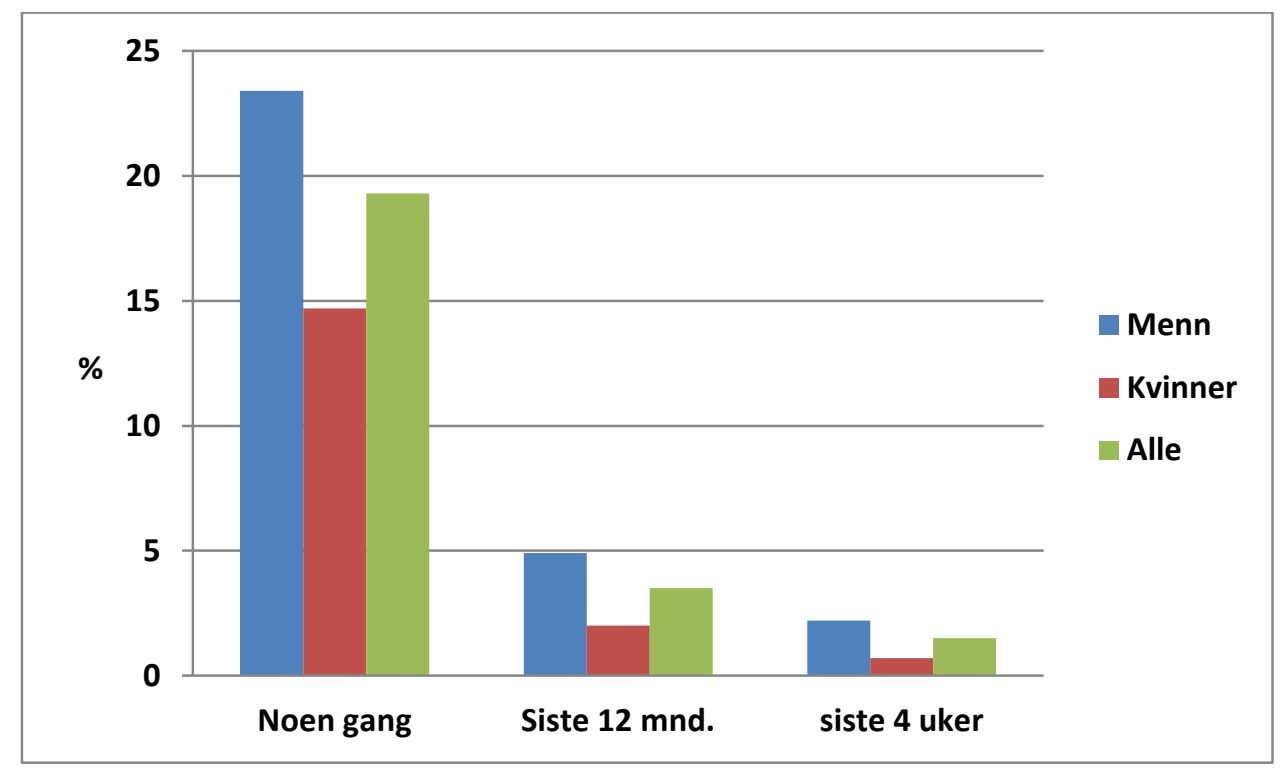

Note: Se vedleggstabell for eksakte prosentandeler.

Det var klart høyest cannabisforbruk blant de yngste, se figur 6.3. I aldersgrupper mellom 35 og 64 år kan forskjellen skyldes tilfeldigheter fordi vi ser på et utvalg av befolkningen. 
Figur 6.3. Andel av befolkningen 16-64 år som har brukt cannabis siste 12 måneder og siste 4 uker. Aldersgrupper.

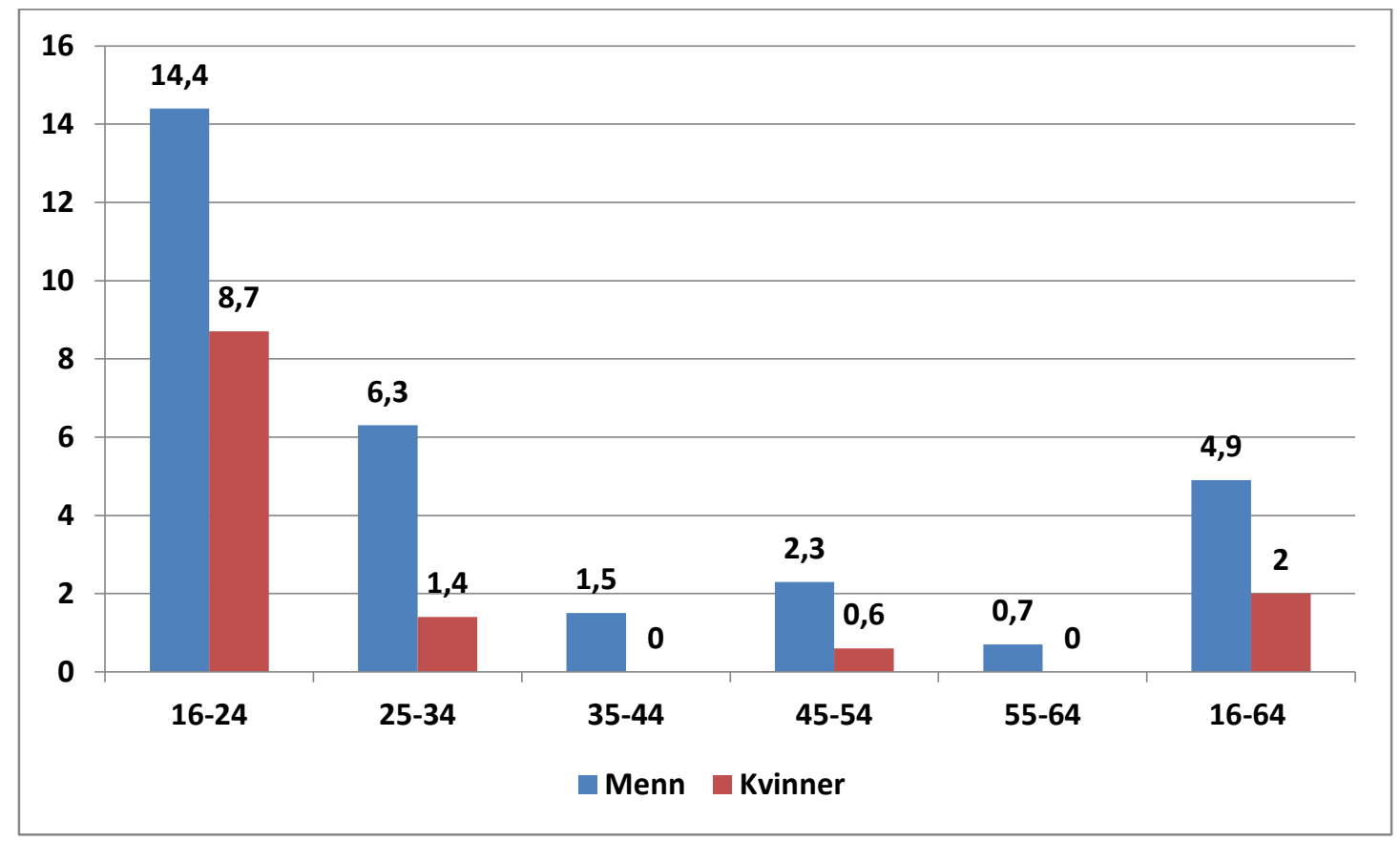

Note: Se vedleggstabell for eksakte prosentandeler.

Over halvparten (55\%) av de som har brukt cannabis hadde gjort dette 1-5 ganger totalt, se figur 6.4. Bare $14 \%$ hadde brukt stoffet mer enn 50 ganger.

Figur 6.4 Cannabisbrukere (brukt noen gang) etter antall ganger stoffet er brukt. Prosent. $\mathrm{N}=320$

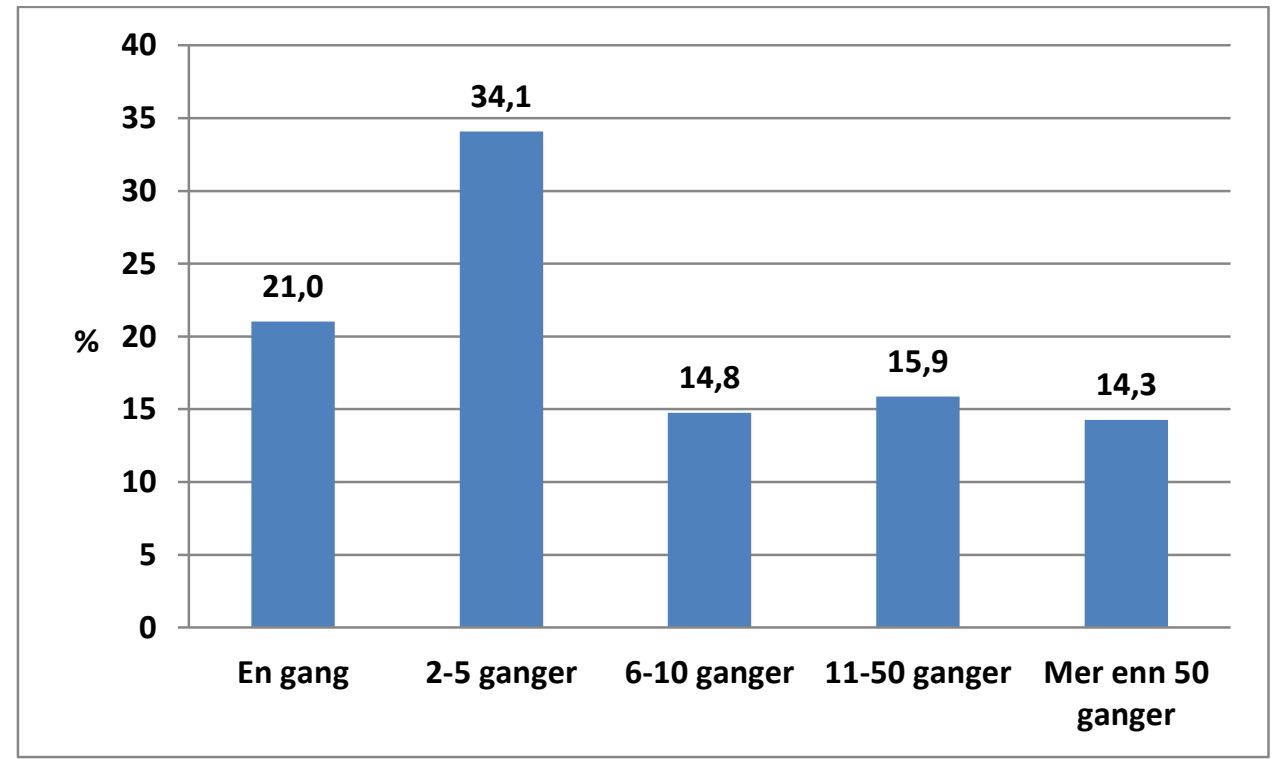


Også blant de som hadde brukt cannabis siste 12 måneder (57 personer), hadde nesten halvparten (46\%) brukt det 1-5 ganger. Tjue prosent hadde brukt det minst 50 ganger eller ca. en gang per uke eller mer. Sett i forhold til hele befolkningen 16-64 år, hadde 0,7 \% brukt cannabis en gang per uke eller mer. Av de som oppga bruk siste 4 uker (26 personer), svarte halvparten at de hadde brukt stoffet 1-3 ganger, mens $19 \%$ svarte at de hadde brukt det 20 dager eller oftere. Dette svarer til at 0,3\% av befolkningen 16-64 år hadde brukt cannabis regelmessig siste 4 uker. Usikkerheten ved anslagene over hyppig bruk er stor.

Universitetsforlaget har publisert en bok med tittel «Hva vet vi om cannabis?». Den gir mye informasjon om cannabisprodukter, mer om utviklingstrekk ved cannabisbruk, norsk cannabiskultur, det norske markedet og konsekvenser av cannabisbruk. Dessuten ser den på lovgivning og rettspraksis i Norge og andre land (Bretteville-Jensen (red), 2013). 


\section{Bruk av vanedannende legemidler}

I SIRUS 2012 inngikk spørsmål om bruk av tre typer av reseptbelagte vanedannende legemidler de siste 12 måneder:

- $\quad$ sovemidler (f.eks. imovane, zopiclon, stilnoct, apodorm,og flunipam)

- beroligende medikamenter (f.eks. sobril, valium og vival)

- $\quad$ smertestillende medikamenter (f.eks. paralgin forte og nobligan)

Slike legemidler kalles vanedannende fordi de ved lengre tids bruk kan føre til avhengighet. Legemidlene kan også i seg selv gi rusopplevelser eller forsterke rusvirkningen av andre rusmidler. Bruk av slike legemidler vil imidlertid for kortere perioder være nyttig behandling for mange personer som har søvnvansker, angst eller smerter (Rossow, 2011). Bruk kan derfor i seg selv ikke ses på som et rus- eller avhengighetsproblem. Men langvarig og hyppig bruk, samt bruk uten forskrivning fra lege, kan tyde på slike problemer. Spørsmålene ble stilt til alle som deltok i undersøkelsen, dvs. personer 16-79 år.

SIRUS har jevnlig gjennomført spørreundersøkelser om bruk av sovemidler og beroligende legemidler siden 1985. Andelen av personer 16-79 år som rapporterte bruk av slike midler var lavere i 2012 enn i 2004, etter en stabil situasjon fra 1994 til 2004 (se figur 7.1). Undersøkelsene i perioden 1985 til 2004 har vært gjennomført på en noe annen måte enn den siste fra 2012, og det er mulig at endringen fra 2004 til 2012 er knyttet til dette. Men metodene og spørsmålsstillingene var såpass nær at det bør gi mening å sammenligne resultatene. 
Figur 7.1 Andel av befolkningen 16-79 år som har brukt sovemidler og beroligende midler i løpet av siste 12 måneder. 1985-2012

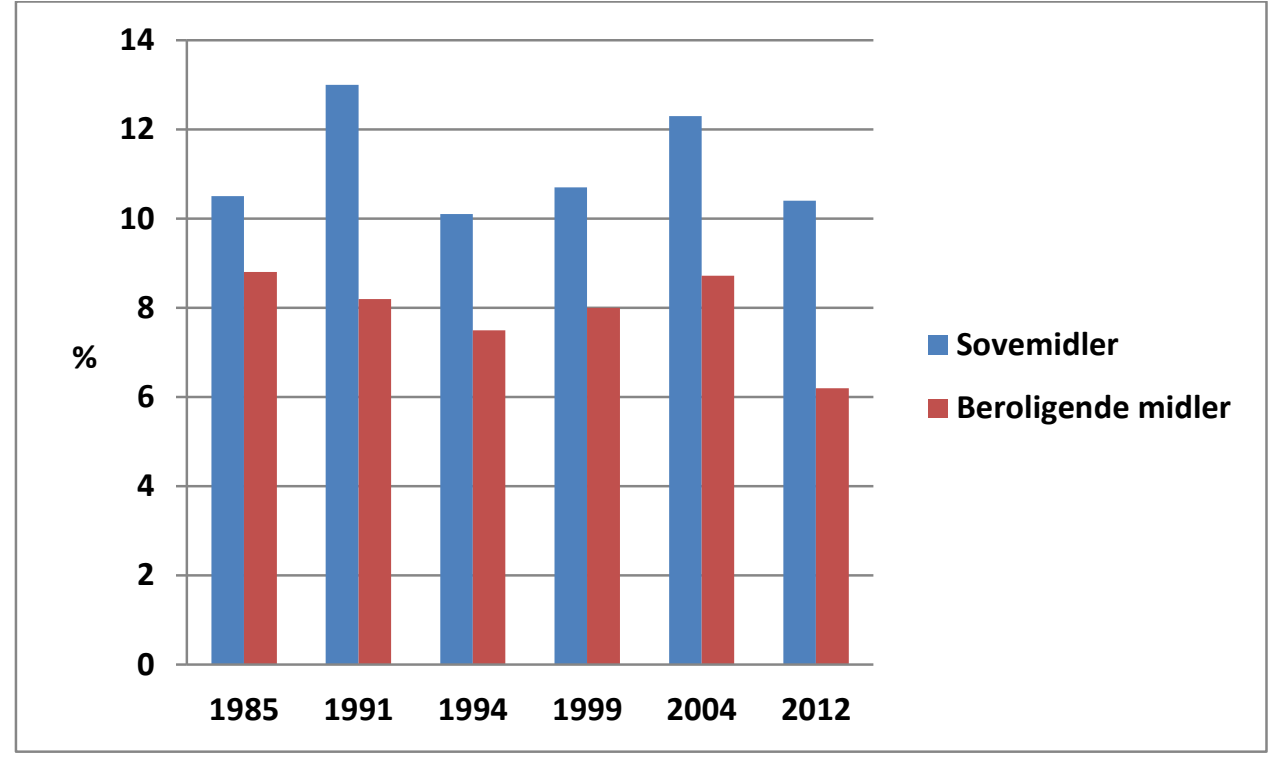

Note: Se vedleggstabell for eksakte prosentandeler.

I 2012 var bruk av smertestillende legemidler mer vanlig enn bruk av sovemidler og beroligende midler, se figur 7.2. I befolkningen hadde 10,4\% brukt sovemidler, 6,2 \% beroligende midler og 25,7 \% hadde brukt smertestillende midler de siste 12 månedene. Det var en større andel kvinner enn menn som brukte sovemidler. For beroligende og smertestillende legemidler kan vi ikke påstå at det var kjønnsforskjeller.

Figur 7.2. Andel av befolkningen 16-79 år som har brukt reseptbelagte sovemidler, beroligende legemidler eller smertestillende legemidler siste 12 måneder. Kvinner og menn

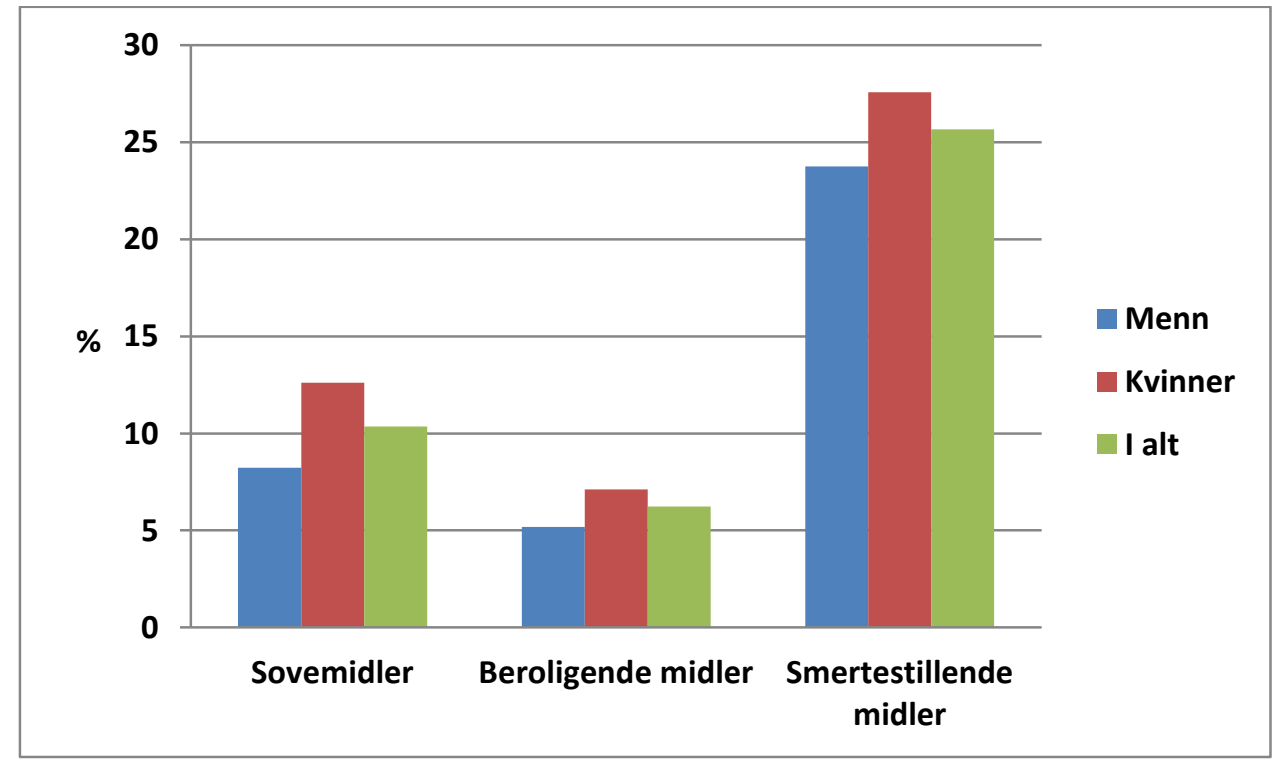

Note: Se vedleggstabell for eksakte prosentandeler. 
Fra 25 års alder var omfang av bruk av sovemidler og beroligende midler i befolkningen høyere jo eldre personene var, se figur 7.3. Bruk av beroligende midler var noe høyere i den yngste aldersgruppen (16-24 år) enn i aldersgruppen 25-34 år. Bruk av smertestillende midler fulgte et noe annet mønster. Det var større omfang av bruk i aldergruppen 35-44 år enn for de yngre, men så var omfanget det samme for alle personer over 45 år.

Figur 7.3. Andel av befolkningen 16-79 år som rapporterer at de har brukt reseptbelagte sovemidler, beroligende legemidler eller smertestillende legemidler siste 12 måneder. Aldersgrupper

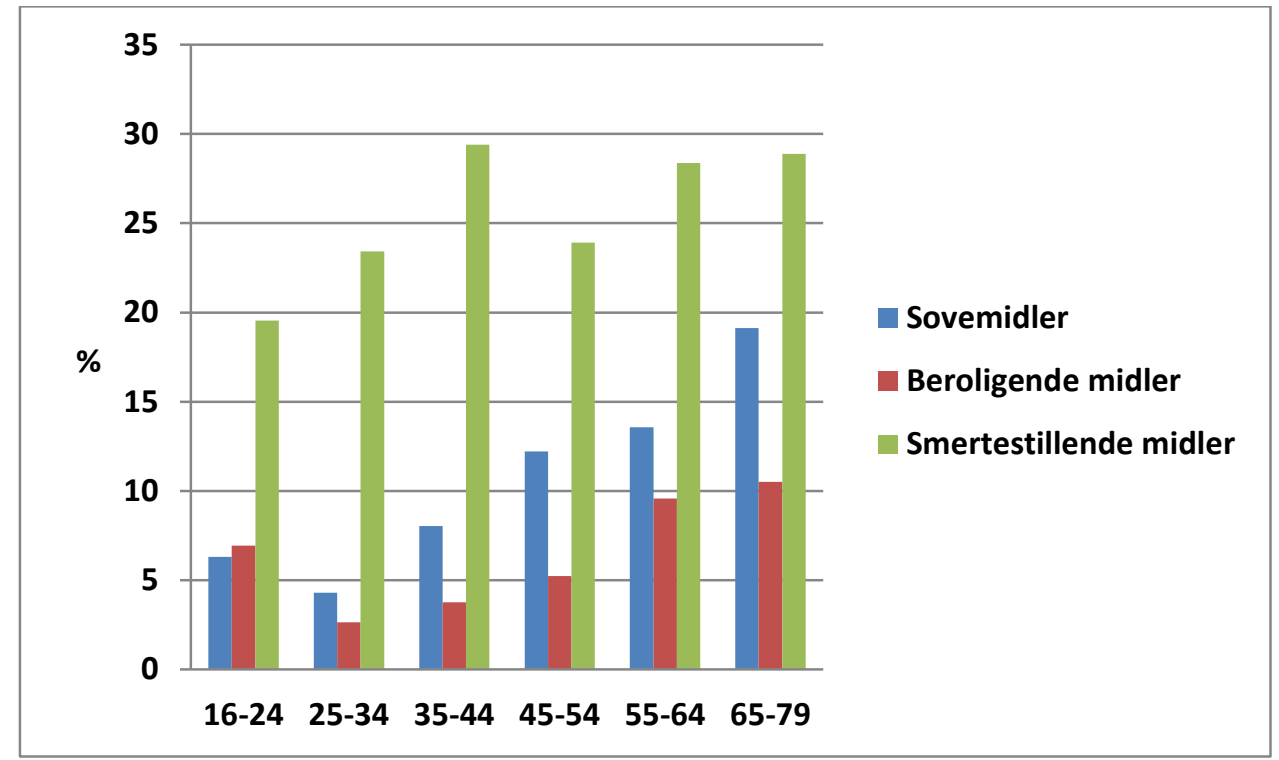

Note: Se vedleggstabell for eksakte prosentandeler.

Varighet av bruk av de tre legemiddeltypene var kortere enn én uke for omtrent halvparten av brukerne. Menn hadde hyppigere enn kvinner brukt sovemidler ut over én uke (62\% vs. 48 $\%)$, mens det for de andre typene av legemidler ikke var noen kjønnsforskjell.

For personer som hadde brukt smertestillende midler sammenhengende mer enn en uke, hadde over halvparten brukt dette maksimalt i 1-2 uker, se figur 7.4. For personer som hadde brukt sovemidler og beroligende midler sammenhengende mer enn én uke, var det vanligere å bruke midlene over lengre perioder: $27 \%$ brukte smertestillende midler mer enn tre måneder, mens $32 \%$ brukte sovemidler og $44 \%$ beroligende midler like lenge. Sovemidler bør ikke brukes sammenhengende ut over to uker, og beroligende midler ikke ut over fire uker. Smertestillende midler kan benyttes lenger hvis det er et gjensidig tillitsforhold og en kontrakt mellom lege og pasient (Helsetilsynet, 2001). 
Figur 7.4. Personer 16-79 år som har brukt vanedannende legemidler daglig over mer enn én uke siste 12 måneder etter varighet av lengste bruksperiode

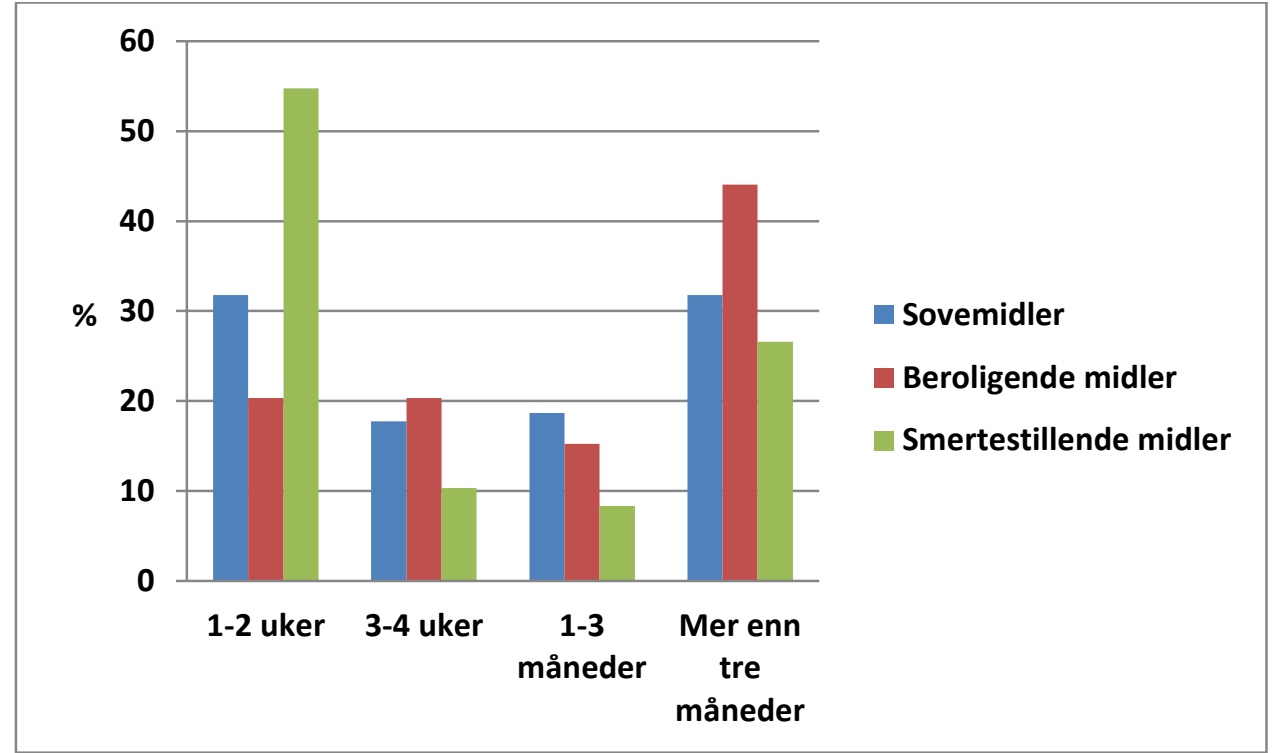

Note: Se vedleggstabell for eksakte prosentandeler.

Sett i forhold til hele befolkningen var det $1,7 \%$ som hadde brukt sovemidler daglig ut over tre måneder. Tilsvarende tall for beroligende midler var 1,3\% og for smertestillende midler $3,4 \%$. Personer med så langvarig bruk kan ha utviklet en avhengighet eller være i faresonen for å utvikle dette. 


\section{Litteratur}

Babor, T. F., Higgins-Biddle, J. C., Saunders, J. B., \& Monteiro, M. G. (2001). The Alcohol Use Disorders Identification Test: Guidelines for Use in Primary Care. (2nd ed.). Geneva: World Health Organization.

Bachs, L. \& Tuv, S. S. (2013). Cannabisprodukter i endring. I A. L. Bretteville-Jensen (red) Hva vet vi om cannabis (s. 17-28). Oslo: Universitetsforlaget.

Bryhni, A. (Ed.) (2006). Rusmidler i Norge 2006. Oslo: SIRUS.

Bye, E. K. og Østhus, S. (2011) Alcohol and cannabis use in Norway during the period 19952009. Norsk epidemiologi, 21 (1): 67-76.

Bye, E.K. og Østhus, S. (2012). Alkoholkonsum blant eldre. Hovedfunn fra spфrreundersфkelser 1985-2008. SIRUS nettrapport 2012. Hentet fra: :

http://www.sirus.no/filestore/Import_vedlegg/Vedlegg_publikasjon/Alkoholkonsumblanteldre .pdf

Del Boca F.K. og Darkes J. (2003) The validity of self-reports of alcohol consumption: state of the science and challenges for research. Addiction, 98,1-12

Drug use in the population (s. 16-19). I O. Hordvin (red) 2005 National report (2004 data) to the EMCDDA by the Reitox National Focal Point. Norway: new development, trends and indepth information on selected issues. . Hentet fra:

http://www.emcdda.europa.eu/attachements.cfm/att_34603_EN_NR2005Norway.pdf

Helsedirektoratet (2013). Tal om tobakk 1973-2012. Oslo: Helsedirektoratet. Hentet fra: http://www.helsedirektoratet.no/publikasjoner/tal-om-tobakk-19732012/Sider/default.aspx

Helsetilsynet (2001). Vanedannende legemidler. Forskrivning og forsvarlighet. IK-2755. Hentet fra:

http://www.helsetilsynet.no/upload/Publikasjoner/andrepublikasjoner/vanedannende_legemidl er_forskrivning_forsvarlighet_ik-2755.pdf

Horverak, Ø. og Bye, E. K. (2007). Det norske drikkemønsteret - En studie basert på intervjudata fra 1973-2004 (SIRUS-rapport 2/2007). Oslo: Statens institutt for rusmiddelforskning. Hentet fra:

http://www.sirus.no/filestore/Import_vedlegg/sirusrap.2.07.pdf 
Lund, K.E., Scheffels, J. \& McNeill, A. (2011). The association between use of snus and quit rates for smoking. Addiction, 106 (1):162-167.

Lund, K.E., McNeill, A. (2013).Patterns of dual use of snus and cigarettes in a mature snus market. Nicotine and Tobacco Research, 15:678-384.

Rossow, I. (2011): Vanedannende legemidler. I A. Skretting og E.E. Storvoll (red)

Utviklingstrekk på rusmiddelfeltet (s. 166-170) (SIRUS-rapport 3/2011). Oslo: Statens

institutt for rusmiddelforskning. Hentet fra

http://www.sirus.no/filestore/Automatisk_opprettede_filer/sirusrap.3.11.pdf

SSB (2013): Statistikkbanken: Tilgjengelig URL 29.10.2013:

https://www.ssb.no/statistikkbanken/selecttable/hovedtabellHjem.asp?KortNavnWeb=alkohol

$\underline{\& C M S S u b j e c t A r e a=}=$ arehandel-og-tjenesteyting \& checked $=$ true

Stockwell, T., Zhao, J., \& Thomas, G. (2009). Should alcohol policies aim to reduce total alcohol consumption? New analyses of Canadian drinking patterns. Addiction Research and Theory, 17, 135-151. 


\section{English summary}

This report presents the main findings of a survey on tobacco consumption and substance use conducted by Statistics Norway on behalf of SIRUS in 2012 (referred to as SIRUS 2012 in what follows). The sample, of persons aged 16-79, was drawn from the Population register (Folkeregisteret), and the response rate was 53 per cent. Interviews were conducted by telephone.

\section{Tobacco in brief}

The proportion of daily smokers in the population has fallen steadily with a particularly marked decline since the millennium. The proportion who smoke occasionally, however, has remained stable at around 10 per cent since the 1970s. The results of SIRUS 2012 show that 14 per cent smoked daily and 9 per cent occasionally. There are about as many women as men who smoke.

Use of smokeless tobacco has increased significantly in recent decades, and it is mainly young men who use snus. In the population as a whole, snus is used by 15 per cent of men and 4 per cent of women on a daily basis, while 6 per cent of men and 4 per cent of women use it occasionally. Among men aged 16-24, 31 per cent use snus daily, 10 per cent occasionally. Use of both cigarettes and smokeless tobacco is not a very common practice: 5 per cent of the population are dual users.

Passive smoking was examined by asking respondents whether people smoked indoors at home. According to 14 per cent of respondents, smoking indoors occurred to some extent (daily, monthly or less often); 7 per cent reported daily indoor smoking at home. Daily smokers were more likely to report smoking at home; 35 per cent of daily smokers reported smoking at home. Of non-smokers, 3 per cent said smoking occurred indoors at home every day.

\section{Alcohol in brief}

Alcohol sales grew by 48 per cent between 1993 and 2008, and then declined somewhat. Growth in the sale of wine accounted for most of this increase. According to previous surveys, the proportion of people who drink alcohol has been growing, as has the proportion who drink relatively often. This rise in drinking frequency has not been accompanied by a corresponding rise in the proportion who gets drunk on a regular basis, however.

Results from SIRUS 2012 show that nine in ten consumed alcohol in the last twelve months. It is still the case that men drink more often, drink more and are more often drunk than women. The youngest age group (16-24) has the highest consumption and the highest intoxication rates. Estimated total consumption was 3.8 litres pure alcohol last year, 5.2 litres 
for men and 2.5 litres for women. The youngest age group consumed most (5.5 litres) and 6579-year-olds least (2.6 litres).

Men drank beer and spirits far more often than women, while women drank wine more often than men. Drinking frequency is markedly higher among people over 44 , and the winedrinking frequency in that age group is also significantly higher. Wine accounts for the largest share of women's alcohol consumption (62 per cent), while for men it is beer ( 49 per cent).

Drinking on Fridays and Saturdays is still common. Seven out of ten drank on private premises (in their own or other people's home), and mainly together with spouse/partner or friends.

\section{Cannabis in brief}

The proportion of the population aged 16-64 reporting ever having used cannabis has been rising steadily, while consumption over the last twelve months and last four weeks (thirty days) has remained stable since 1985. In 2012, two in ten people aged 16-64 reported using cannabis at least once in their lifetime, 3.4 per cent had used it in the last twelve months and 1.5 per cent in the last four weeks. More men use cannabis than women, and it is more common among 16-24-year-olds. High consumption frequency of cannabis was reported by 0.3 per cent of the population. By high frequency we mean consumption of the drug on more than twenty days in the past four weeks.

\section{Pharmaceuticals in brief}

In 2012, one in ten people aged 16-79 reported having used prescription sleeping drugs in the last twelve months. More women than men reported such use. Among people aged 25 and over, the proportion using sleeping pills increases with age.

Six per cent had used prescription sedatives in the last twelve months. We found no gender difference in the use of sedatives. As in the case of prescription sleeping drugs, the percentage of people aged 25 and over using sedatives increases with age.

One in four had used prescription painkillers, and we found no gender difference for these drugs either. The proportion of people reporting having used analgesics was higher among 35-44-year-olds than among younger respondents, and stable among all persons over 45 years of age.

The proprtion of the population aged 16-79 years using prescription sleeping medication on a daily basis or over an extended period (more than three months in the past twelve months) was 1.7; corresponding figures for prescription tranquilizers were 1.3 per cent and 3.4 per cent for prescription pain relievers. 


\section{Vedleggstabeller til tobakkskapitlet}

Vedleggstabell til figur 2.6 Andel av befolkningen etter røykestatus. Prosent. Aldersgrupper. $\mathrm{N}=1949$.

\begin{tabular}{|c|c|c|c|c|c|c|c|}
\hline & $\mathbf{1 6 - 2 4}$ & $\mathbf{2 5 - 3 4}$ & $\mathbf{3 5 - 4 4}$ & $\mathbf{4 5 - 5 4}$ & $\mathbf{5 5 - 6 4}$ & $\mathbf{6 5 - 7 9}$ & Totalt \\
\hline Daglig & 9,2 & 12,5 & 15,4 & 19,2 & 14,5 & 12,2 & 14,0 \\
\hline Av-og-til & 16,8 & 13,2 & 10,0 & 5,5 & 5,3 & 2,2 & 8,9 \\
\hline Tidligere & 22,8 & 33,9 & 36,3 & 43,9 & 50,7 & 49,5 & 39,2 \\
\hline Aldri & 51,3 & 40,5 & 38,3 & 31,4 & 29,6 & 36,2 & 37,9 \\
\hline Totalt $(\mathrm{N})$ & $\begin{array}{c}100 \% \\
(\mathrm{~N}=316)\end{array}$ & $\begin{array}{c}100 \% \\
(\mathrm{~N}=304)\end{array}$ & $\begin{array}{c}100 \% \\
(\mathrm{~N}=402)\end{array}$ & $\begin{array}{c}100 \% \\
(\mathrm{~N}=344)\end{array}$ & $\begin{array}{c}100 \% \\
(\mathrm{~N}=304)\end{array}$ & $\begin{array}{c}100 \% \\
(\mathrm{~N}=279)\end{array}$ & $\begin{array}{c}100 \% \\
(\mathrm{~N}=1949)\end{array}$ \\
\hline
\end{tabular}

Vedleggstabell til figur 2.6. Røykestatus blant menn i ulike aldersgrupper. Prosent.

\begin{tabular}{|c|c|c|c|c|c|c|c|}
\hline & $\mathbf{1 6 - 2 4}$ & $\mathbf{2 5 - 3 4}$ & $\mathbf{3 5 - 4 4}$ & $\mathbf{4 5 - 5 4}$ & $\mathbf{5 5 - 6 4}$ & $\mathbf{6 5 - 7 9}$ & Totalt \\
\hline Daglig & 7,8 & 14,4 & 16,5 & 19,4 & 18,0 & 11,9 & 14,8 \\
\hline Av-og-til & 18,1 & 15,0 & 8,0 & 6,3 & 4,7 & 3,0 & 9,3 \\
\hline Tidligere & 22,9 & 36,2 & 40,0 & 41,1 & 48,7 & 63,0 & 41,2 \\
\hline Aldri & 51,2 & 34,4 & 35,5 & 33,1 & 28,7 & 22,2 & 34,7 \\
\hline Totalt & $\begin{array}{c}100 \% \\
(\mathrm{~N}=166)\end{array}$ & $\begin{array}{c}100 \% \\
(\mathrm{~N}=160)\end{array}$ & $\begin{array}{c}100 \% \\
(\mathrm{~N}=200)\end{array}$ & $\begin{array}{c}100 \% \\
(\mathrm{~N}=175)\end{array}$ & $\begin{array}{c}100 \% \\
(\mathrm{~N}=150)\end{array}$ & $\begin{array}{c}100 \% \\
(\mathrm{~N}=135)\end{array}$ & $\begin{array}{c}100 \% \\
(\mathrm{~N}=986)\end{array}$ \\
\hline
\end{tabular}

Vedleggstabell til figur 2.6. Røykestatus blant kvinner i ulike aldersgrupper. Prosent.

\begin{tabular}{|c|c|c|c|c|c|c|c|}
\hline & $\mathbf{1 6 - 2 4}$ & $\mathbf{2 5 - 3 4}$ & $\mathbf{3 5 - 4 4}$ & $\mathbf{4 5 - 5 4}$ & $\mathbf{5 5 - 6 4}$ & $\mathbf{6 5 - 7 9}$ & Totalt \\
\hline Daglig & 10,7 & 10,4 & 14,0 & 18,9 & 11,2 & 12,5 & 13,1 \\
\hline Av-og-til & 14,7 & 11,1 & 12,0 & 4,7 & 5,9 & 1,4 & 8,4 \\
\hline Tidligere & 22,7 & 31,2 & 32,5 & 46,7 & 52,6 & 36,8 & 37,1 \\
\hline Aldri & 52,0 & 47,2 & 41,5 & 29,6 & 30,3 & 49,3 & 41,3 \\
\hline Totalt & $\begin{array}{c}100 \% \\
(\mathrm{~N}=150)\end{array}$ & $\begin{array}{c}100 \% \\
(\mathrm{~N}=144)\end{array}$ & $\begin{array}{c}100 \% \\
(\mathrm{~N}=200)\end{array}$ & $\begin{array}{c}100 \% \\
(\mathrm{~N}=169)\end{array}$ & $\begin{array}{c}100 \% \\
(\mathrm{~N}=152)\end{array}$ & $\begin{array}{c}100 \% \\
(\mathrm{~N}=144)\end{array}$ & $\begin{array}{c}100 \% \\
(\mathrm{~N}=959)\end{array}$ \\
\hline
\end{tabular}

Vedleggstabell til figur 2.9 Snusbrukerstatus blant menn i ulike aldersgrupper. Prosent.

\begin{tabular}{|c|c|c|c|c|c|c|c|}
\hline & $\mathbf{1 6 - 2 4}$ & $\mathbf{2 5 - 3 4}$ & $\mathbf{3 5 - 4 4}$ & $\mathbf{4 5 - 5 4}$ & $\mathbf{5 5 - 6 4}$ & $\mathbf{6 5 - 7 9}$ & Totalt \\
\hline Daglig & 31,3 & 18,2 & 13,9 & 13,1 & 9,3 & 3,0 & 15,2 \\
\hline Av-og-til & 9,6 & 8,8 & 6,0 & 5,7 & 5,3 & 0,7 & 6,2 \\
\hline Tidligere & 13,3 & 28,9 & 22,9 & 14,9 & 13,2 & 11,1 & 17,7 \\
\hline Aldri & 45,8 & 44,0 & 57,2 & 66,3 & 72,2 & 85,2 & 60,9 \\
\hline Totalt & $\begin{array}{c}100 \% \\
(\mathrm{~N}=166)\end{array}$ & $\begin{array}{c}100 \% \\
(\mathrm{~N}=159)\end{array}$ & $\begin{array}{c}100 \% \\
(\mathrm{~N}=201)\end{array}$ & $\begin{array}{c}100 \% \\
(\mathrm{~N}=175)\end{array}$ & $\begin{array}{c}100 \% \\
(\mathrm{~N}=151)\end{array}$ & $\begin{array}{c}100 \% \\
(\mathrm{~N}=135)\end{array}$ & $\begin{array}{c}100 \% \\
(\mathrm{~N}=987)\end{array}$ \\
\hline
\end{tabular}


Vedleggstabell til figur 2.9 Snusbrukerstatus blant kvinner i ulike aldersgrupper. Prosent.

\begin{tabular}{|c|c|c|c|c|c|c|c|}
\hline & $\mathbf{1 6 - 2 4}$ & $\mathbf{2 5 - 3 4}$ & $\mathbf{3 5 - 4 4}$ & $\mathbf{4 5 - 5 4}$ & $\mathbf{5 5 - 6 4}$ & $\mathbf{6 5 - 7 9}$ & Totalt \\
\hline Daglig & 16,7 & 2,8 & 2,5 & 0,6 & 0,0 & 0,0 & 3,6 \\
\hline Av-og-til & 14,0 & 5,6 & 3,0 & 0,6 & 0,0 & 0,0 & 3,8 \\
\hline Tidligere & 16,7 & 16,7 & 5,0 & 2,4 & 0,7 & 0,0 & 6,7 \\
\hline Aldri & 52,7 & 75,0 & 89,6 & 96,4 & 99,3 & 100 & 85,9 \\
\hline Totalt & $\begin{array}{c}100 \% \\
(\mathrm{~N}=150)\end{array}$ & $\begin{array}{c}100 \% \\
(\mathrm{~N}=144)\end{array}$ & $\begin{array}{c}100 \% \\
(\mathrm{~N}=201)\end{array}$ & $\begin{array}{c}100 \% \\
(\mathrm{~N}=168)\end{array}$ & $\begin{array}{c}100 \% \\
(\mathrm{~N}=153)\end{array}$ & $\begin{array}{c}100 \% \\
(\mathrm{~N}=144)\end{array}$ & $\begin{array}{c}100 \% \\
(\mathrm{~N}=960)\end{array}$ \\
\hline
\end{tabular}

Vedleggstabell til figur 2.11. Andel av befolkningen 16-79 år som rapporterer at det røykes innendørs hjemme, med ulik røykestatus. Prosent. $\mathrm{N}=1944$.

\begin{tabular}{|l|c|c|c|c|}
\hline & Daglig & Av-og-til & Røyker ikke & Totalt \\
\hline $\begin{array}{l}\text { Røykes hjemme } \\
\text { daglig/ukentlig }\end{array}$ & 34,9 & 8,0 & 3,3 & 8,1 \\
\hline $\begin{array}{l}\text { Røykers hjemme } \\
\text { månedlig/sjeldnere }\end{array}$ & 8,8 & 10,3 & 4,3 & 5,5 \\
\hline $\begin{array}{l}\text { Røykes aldri } \\
\text { hjemme }\end{array}$ & 56,3 & 81,6 & 92,5 & 86,4 \\
\hline Totalt & $\begin{array}{c}100 \% \\
(\mathrm{~N}=272)\end{array}$ & $\begin{array}{c}100 \% \\
(\mathrm{~N}=174)\end{array}$ & $\begin{array}{c}100 \% \\
(\mathrm{~N}=1498)\end{array}$ & $\begin{array}{c}100 \% \\
(\mathrm{~N}=1944)\end{array}$ \\
\hline
\end{tabular}

\section{Vedleggstabeller til alkoholkapitlene.}

Vedleggstabell til figur 3.2 Drikkefrekvens siste 12 måneder blant menn og kvinner.

\begin{tabular}{|l|c|c|c|c|c|c|}
\hline & \multicolumn{3}{|c|}{ Prosenter } & \multicolumn{3}{|c|}{ Absolutte tall } \\
\hline & Mann & Kvinne & Total & Mann & Kvinne & Total \\
\hline $\begin{array}{l}\text { 4 dg. uken } \\
\text { el. mer }\end{array}$ & $3,2 \%$ & $2,4 \%$ & $2,8 \%$ & 32 & 23 & 55 \\
\hline $\begin{array}{l}\text { 2-3 dager } \\
\text { i uken }\end{array}$ & $15,4 \%$ & $13,1 \%$ & $14,3 \%$ & 152 & 126 & 278 \\
\hline $\begin{array}{l}\text { ca 1 dag i } \\
\text { uken }\end{array}$ & $26,2 \%$ & $17,7 \%$ & $22,0 \%$ & 258 & 170 & 428 \\
\hline $\begin{array}{l}\text { 2-3 dg. } \\
\text { mnd. }\end{array}$ & $18,7 \%$ & $16,0 \%$ & $17,3 \%$ & 184 & 153 & 337 \\
\hline $\begin{array}{l}\text { ca 1 dag i } \\
\text { mnd. }\end{array}$ & $7,4 \%$ & $9,8 \%$ & $8,6 \%$ & 73 & 94 & 167 \\
\hline $\begin{array}{l}\text { Noen få } \\
\text { dager/en } \\
\text { dag i året }\end{array}$ & $19,3 \%$ & $26,5 \%$ & $22,8 \%$ & 190 & 254 & 444 \\
\hline $\begin{array}{l}\text { lkke } \\
\text { drukket }\end{array}$ & $9,8 \%$ & $14,5 \%$ & $12,1 \%$ & 97 & 139 & 236 \\
\hline
\end{tabular}


Vedleggstabell til figur 3.3 Drikkefrekvens siste 12 måneder i ulike aldersgrupper. Prosent.

\begin{tabular}{|c|c|c|c|c|c|c|}
\hline & \multicolumn{6}{|c|}{ Alder } \\
\hline & $16-24$ & $25-34$ & $35-44$ & $45-54$ & $55-64$ & $65-79$ \\
\hline Ukentlig & 28,7 & 35,3 & 31,4 & 48,5 & 52,8 & 39,9 \\
\hline Månedlig & 36,9 & 32,3 & 30,4 & 20,1 & 16,8 & 16,9 \\
\hline Sjeldnere & 21,8 & 24,1 & 28,2 & 20,6 & 18,2 & 22,7 \\
\hline $\begin{array}{l}\text { lkke } \\
\text { drukket }\end{array}$ & 12,6 & 8,3 & 10 & 10,8 & 12,2 & 20,5 \\
\hline Total & $\begin{array}{c}100 \\
(n=317)\end{array}$ & $\begin{array}{c}100 \\
(\mathrm{~N}=304)\end{array}$ & $\begin{array}{c}100 \\
(n=403)\end{array}$ & $\begin{array}{c}100 \\
(n=344)\end{array}$ & $\begin{array}{c}100 \\
(n=303)\end{array}$ & $\begin{array}{c}100 \\
(n=278)\end{array}$ \\
\hline
\end{tabular}

Vedleggstabell til figur 3.4 Beruselsesfrekvens siste 12 måneder blant menn og kvinner.

\begin{tabular}{|l|c|c|c|c|c|c|c|}
\hline & \multicolumn{3}{|c|}{ Prosenter } & \multicolumn{3}{c|}{ Absolutte tall } \\
\hline & Mann & Kvinne & Total & Mann & Kvinne & Total \\
\hline Ukentlig & $3,6 \%$ & $1,4 \%$ & $2,5 \%$ & 36 & 13 & 49 \\
\hline Månedlig & $11,4 \%$ & $4,8 \%$ & $8,2 \%$ & 113 & 46 & 159 \\
\hline Sjeldnere & $43,1 \%$ & $34,3 \%$ & $38,8 \%$ & 425 & 330 & 755 \\
\hline $\begin{array}{l}\text { lkke } \\
\text { beruset }\end{array}$ & $41,8 \%$ & $59,5 \%$ & $50,6 \%$ & 413 & 572 & 985 \\
\hline Total & $100,0 \%$ & $100,0 \%$ & $100,0 \%$ & 987 & 961 & 1948 \\
\hline
\end{tabular}

Vedleggstabell til figur 3.5 Beruselsesfrekvens siste 12 måneder i ulike aldersgrupper. Prosent.

\begin{tabular}{|c|c|c|c|c|c|c|}
\hline & \multicolumn{6}{|c|}{ Alder } \\
\hline & $16-24$ & $25-34$ & $35-44$ & $45-54$ & $55-64$ & $65-79$ \\
\hline Ukentlig & 7,3 & 3,3 & 1,2 & 2,3 & 1 & 0 \\
\hline Månedlig & 20,2 & 9,5 & 6,7 & 8,7 & 2,3 & 0,7 \\
\hline Sjeldnere & 41,3 & 55,9 & 47,8 & 35,3 & 32 & 15,8 \\
\hline $\begin{array}{l}\text { Ingen } \\
\text { ganger }\end{array}$ & 31,2 & 31,3 & 44,3 & 53,6 & 64,7 & 83,5 \\
\hline Total & $\begin{array}{c}100 \\
(n=317)\end{array}$ & $\begin{array}{c}100 \\
(\mathrm{~N}=304)\end{array}$ & $\begin{array}{c}100 \\
(n=402)\end{array}$ & $\begin{array}{c}100 \\
(n=343)\end{array}$ & $\begin{array}{c}100 \\
(n=303)\end{array}$ & $\begin{array}{c}100 \\
(\mathrm{n}=278)\end{array}$ \\
\hline
\end{tabular}


Vedleggstabell til figur 3.6 Andel av befolkningen 16-79 år som har drukket 6 enheter alkohol eller mer ved en og samme anledning siste 12 måneder. Kvinner og menn.

\begin{tabular}{|l|c|c|c|c|c|c|}
\hline & \multicolumn{3}{|c|}{ Prosenter } & \multicolumn{3}{c|}{ Absolutte tall } \\
\cline { 2 - 7 } & Mann & Kvinne & Total & Mann & Kvinne & Total \\
\hline $\begin{array}{l}\text { Ingen } \\
\text { ganger }\end{array}$ & $38,3 \%$ & $61,2 \%$ & $49,6 \%$ & 378 & 588 & 966 \\
\hline $\begin{array}{l}\text { Sjeldnere } \\
\text { enn } \\
\text { månedlig }\end{array}$ & $37,9 \%$ & $27,3 \%$ & $32,7 \%$ & 374 & 262 & 636 \\
\hline Månedlig & $17,1 \%$ & $8,2 \%$ & $12,7 \%$ & 169 & 79 & 248 \\
\hline Ukentlig & $6,6 \%$ & $3,3 \%$ & $5,0 \%$ & 65 & 32 & 97 \\
\hline Total & $100,0 \%$ & $100,0 \%$ & $100,0 \%$ & 986 & 961 & 1947 \\
\hline
\end{tabular}

Vedleggstabell til figur 3.7 Andel av befolkningen 16-79 år som har drukket 6 enheter alkohol eller mer ved en og samme anledning siste 12 måneder. Alder. Prosent.

\begin{tabular}{|c|c|c|c|c|c|c|}
\hline & & & & & & \\
\hline & $16-24$ & $25-34$ & $35-44$ & $45-54$ & $55-64$ & $65-79$ \\
\hline Ukentlig & 10,0 & 5,9 & 3,9 & 4,9 & 2,7 & 2,4 \\
\hline Månedlig & 26,8 & 19,1 & 11,2 & 11,0 & 5,9 & 1,4 \\
\hline Sjeldnere & 31,9 & 41,6 & 43,8 & 31,7 & 28,7 & 13,3 \\
\hline $\begin{array}{l}\text { Ingen } \\
\text { ganger }\end{array}$ & 31,2 & 33,3 & 41,0 & 52,3 & 62,7 & 82,8 \\
\hline Total & $\begin{array}{c}100 \\
(n=317)\end{array}$ & $\begin{array}{c}100 \\
(\mathrm{~N}=303)\end{array}$ & $\begin{array}{c}100 \\
(n=401)\end{array}$ & $\begin{array}{c}100 \\
(n=344)\end{array}$ & $\begin{array}{c}100 \\
(n=303)\end{array}$ & $\begin{array}{c}100 \\
(n=279)\end{array}$ \\
\hline
\end{tabular}

Vedleggstabell til figur 3.8 Frekvens for bruk av alkohol på serveringssteder siste 12 mnd. blant kvinner og menn.

\begin{tabular}{|l|c|c|c|c|c|c|c|}
\hline & \multicolumn{3}{|c|}{ Prosenter } & \multicolumn{3}{c|}{ Absolutte tall } \\
\hline & Mann & Kvinne & Total & Mann & Kvinne & Total \\
\hline $\begin{array}{l}\text { 1 dg. uken } \\
\text { el. mer }\end{array}$ & $5,2 \%$ & $3,4 \%$ & $4,3 \%$ & 51 & 33 & 84 \\
\hline $\begin{array}{l}\text { 2-3 dg. } \\
\text { mnd. }\end{array}$ & $6,8 \%$ & $3,6 \%$ & $5,2 \%$ & 67 & 35 & 102 \\
\hline $\begin{array}{l}\text { 1 dag } \\
\text { mnd. }\end{array}$ & $10,6 \%$ & $7,4 \%$ & $9,0 \%$ & 105 & 71 & 176 \\
\hline $\begin{array}{l}\text { Noen få } \\
\text { dg./en dag }\end{array}$ & $50,2 \%$ & $51,5 \%$ & $50,8 \%$ & 495 & 495 & 990 \\
\hline $\begin{array}{l}\text { Ingen } \\
\text { ganger }\end{array}$ & $27,3 \%$ & $34,0 \%$ & $30,6 \%$ & 269 & 327 & 596 \\
\hline Total & $100,0 \%$ & $100,0 \%$ & $100,0 \%$ & 987 & 961 & 1948 \\
\hline
\end{tabular}


Vedleggstabell til figur 3.9 Frekvens for bruk av alkohol på serveringssteder siste 12 mnd. I ulike aldersgrupper. Prosent.

\begin{tabular}{|l|c|c|c|c|c|c|}
\hline & \multicolumn{7}{|c|}{ Alder } \\
\hline Ukentlig & $\mathbf{1 6 - 2 4}$ & $\mathbf{2 5 - 3 4}$ & $\mathbf{3 5 - 4 4}$ & $\mathbf{4 5 - 5 4}$ & $\mathbf{5 5 - 6 4}$ & $\mathbf{6 5 - 7 9}$ \\
\hline Månedlig & 10,1 & 8,3 & 2 & 1,7 & 3 & 1,4 \\
\hline Sjeldnere & 20,3 & 19,8 & 13,5 & 17,2 & 8,9 & 4,6 \\
\hline Ingen & 37 & 51,8 & 58,5 & 57,3 & 54,1 & 42,9 \\
\hline dager & 32,6 & 20,1 & 26 & 23,8 & 34 & 51,1 \\
\hline Total & 100 & 100 & 100 & 100 & 100 & 100 \\
& $(n=316)$ & $(N=303)$ & $(n=400)$ & $(n=344)$ & $(n=303)$ & $(n=280)$ \\
\hline
\end{tabular}

Vedleggstabell til figur 4.1 Andel kvinner og menn som har drukket de ulike drikkesortene siste 4 uker.

\begin{tabular}{|l|c|c|c|c|c|c|}
\hline & \multicolumn{3}{|c|}{ Prosenter } & \multicolumn{3}{c|}{ Absolutte tall } \\
\hline & Mann & Kvinne & Total & Mann & Kvinne & $\begin{array}{c}\text { Total } \\
(n=1947)\end{array}$ \\
\hline ØI & & & & & & \\
\hline $\begin{array}{l}\text { Drukket } \\
\text { Vin }\end{array}$ & $65,3 \%$ & $30,1 \%$ & $47,9 \%$ & 644 & 289 & 933 \\
\hline $\begin{array}{l}\text { Drukket } \\
\text { Brennevin }\end{array}$ & $47,8 \%$ & $55,5 \%$ & $51,6 \%$ & 472 & 533 & 1005 \\
\hline $\begin{array}{l}\text { Drukket } \\
\text { Rusbrus }\end{array}$ & $38,6 \%$ & $17,6 \%$ & $28,2 \%$ & 381 & 169 & 550 \\
\hline Drukket & $7,0 \%$ & $11,2 \%$ & $9,1 \%$ & 69 & 108 & 177 \\
\hline
\end{tabular}

Vedleggstabell til figur 4.2 Andel av befolkningen 16-79 år som har drukket de ulike drikkesortene siste 4 uker (flere svar mulig). Aldersgrupper. Prosent.

\begin{tabular}{|l|c|c|c|c|c|c|}
\hline & \multicolumn{6}{|c|}{ Alder } \\
\hline Øા & $\mathbf{1 6 - 2 4}$ & $\mathbf{2 5 - 3 4}$ & $\mathbf{3 5 - 4 4}$ & $\mathbf{4 5 - 5 4}$ & $\mathbf{5 5 - 6 4}$ & $\mathbf{6 5 - 7 9}$ \\
\hline Vin & 50,2 & 58,1 & 47,1 & 50,6 & 47,5 & 33,0 \\
\hline Brennevin & 40,1 & 52,6 & 50,1 & 58,9 & 62,4 & 45,2 \\
\hline Rusbrus & 36,9 & 32,0 & 25,7 & 24,1 & 26,4 & 25,0 \\
\hline & 26,9 & 9,6 & 7,7 & 4,7 & 3,0 & 2,2 \\
\hline & $(n=317)$ & $(\mathrm{N}=304)$ & $(\mathrm{n}=401)$ & $(\mathrm{n}=343)$ & $(\mathrm{n}=303)$ & $(\mathrm{n}=279)$ \\
\hline
\end{tabular}


Vedleggstabell til Tabell 4.1. Gjennomsnittlig frekvens for bruk av ulike drikkesorter siste 4 uker. Kvinner og menn, alder. Gjennomsnitt, standardavvik og antall.

\begin{tabular}{|c|c|c|c|c|c|}
\hline & & Øા & Vin & Brennevin & Rusbrus \\
\hline \multirow{3}{*}{ Mann } & Gjennomsnitt & 3,1 & 2,3 & 1,1 & 0,2 \\
\hline & Standardavvik & 4,9 & 4,5 & 2,6 & 1,5 \\
\hline & $\mathrm{N}$ & 986 & 986 & 986 & 986 \\
\hline \multirow{3}{*}{ Kvinne } & Gjennomsnitt & 1,0 & 2,7 & 0,4 & 0,3 \\
\hline & Standardavvik & 2,7 & 4,5 & 1,7 & 1,2 \\
\hline & $\mathrm{N}$ & 961 & 961 & 961 & 961 \\
\hline \multirow{3}{*}{ Total } & Gjennomsnitt & 2,1 & 2,5 & 0,8 & 0,2 \\
\hline & Standardavvik & 4,1 & 4,5 & 2,2 & 1,4 \\
\hline & $\mathrm{N}$ & 1947 & 1947 & 1947 & 1947 \\
\hline \multirow{3}{*}{$16-24$} & Gjennomsnitt & 2,2 & 1,4 & 1,1 & 0,9 \\
\hline & Standardavvik & 4,4 & 3,4 & 3,2 & 3,0 \\
\hline & $\mathrm{N}$ & 317 & 317 & 317 & 317 \\
\hline \multirow{3}{*}{$25-34$} & Gjennomsnitt & 2,5 & 1,7 & 0,7 & 0,2 \\
\hline & Standardavvik & 4,1 & 3,1 & 1,6 & 0,6 \\
\hline & $\mathrm{N}$ & 303 & 303 & 303 & 303 \\
\hline \multirow{3}{*}{$35-44$} & Gjennomsnitt & 1,6 & 1,8 & 0,6 & 0,1 \\
\hline & Standardavvik & 3,1 & 3,2 & 1,7 & 0,4 \\
\hline & $\mathrm{N}$ & 401 & 401 & 401 & 401 \\
\hline \multirow{3}{*}{$45-54$} & Gjennomsnitt & 2,2 & 3,2 & 0,5 & 0,1 \\
\hline & Standardavvik & 4,2 & 4,7 & 1,6 & 1,0 \\
\hline & $\mathrm{N}$ & 344 & 344 & 344 & 344 \\
\hline \multirow{3}{*}{$55-64$} & Gjennomsnitt & 2,2 & 3,6 & 0,9 & 0,1 \\
\hline & Standardavvik & 4,5 & 5,2 & 2,5 & 0,6 \\
\hline & $\mathrm{N}$ & 303 & 303 & 303 & 303 \\
\hline \multirow{3}{*}{$65-79$} & Gjennomsnitt & 1,7 & 3,5 & 0,9 & 0,0 \\
\hline & Standardavvik & 4,3 & 6,5 & 2,4 & 0,2 \\
\hline & $\mathrm{N}$ & 279 & 279 & 279 & 279 \\
\hline \multirow{3}{*}{ Total } & Gjennomsnitt & 2,1 & 2,5 & 0,8 & 0,2 \\
\hline & Standardavvik & 4,1 & 4,5 & 2,2 & 1,4 \\
\hline & $\mathrm{N}$ & 1947 & 1947 & 1947 & 1947 \\
\hline
\end{tabular}


Vedleggstabell til figur 4.3 Andel alkohol fra ulike drikkesorter. Kvinner og menn.

\begin{tabular}{|l|c|c|c|c|c|}
\hline $\begin{array}{c}\text { Liter ren } \\
\text { alkohol }\end{array}$ & ØI & Vin & Brennevin & Rusbrus & SUM \\
\hline Menn & 2,51 & 1,50 & 1,00 & 0,14 & 5,16 \\
\hline Kvinner & 0,58 & 1,54 & 0,25 & 0,11 & 2,48 \\
\hline Andeler \% & & & & & \\
\hline Mann & 48,7 & 29,2 & 19,4 & 2,8 & \\
\hline Kvinne & 23,3 & 62,4 & 9,9 & 4,4 & \\
\hline
\end{tabular}

Vedleggstabell til figur 4.4 Andel alkohol fra ulike drikkesorter, ulike aldersgrupper. Prosent.

\begin{tabular}{|l|c|c|c|c|}
\hline & $\varnothing \mathbf{I}$ & Vin & Brennevin & Rusbrus/cider \\
\hline $16-24$ & 43,5 & 17,4 & 29,5 & 9,6 \\
\hline $25-34$ & 57,7 & 25,8 & 14,1 & 2,4 \\
\hline $35-44$ & 40,4 & 47,7 & 10,3 & 1,6 \\
\hline $45-54$ & 34,8 & 50,9 & 12,8 & 1,5 \\
\hline $55-64$ & 38,1 & 49,2 & 12,1 & 0,6 \\
\hline $65-79$ & 20,3 & 66,1 & 13,2 & 0,5 \\
\hline
\end{tabular}

Vedleggstabell til figur 5.1 Andel av befolkningen 16-79 år som drakk på ukedager eller helg sist de drakk alkohol. Kvinner og menn.

\begin{tabular}{|l|c|c|c|c|c|c|c|}
\hline & \multicolumn{3}{|c|}{ Prosenter } & \multicolumn{3}{c|}{ Absolutte tall } \\
\hline & Mann & Kvinne & Total & Mann & Kvinne & Total \\
\hline Mandag & $4,9 \%$ & $3,7 \%$ & $4,3 \%$ & 43 & 30 & 73 \\
\hline Tirsdag & $4,2 \%$ & $5,0 \%$ & $4,6 \%$ & 37 & 41 & 78 \\
\hline Onsdag & $5,8 \%$ & $4,9 \%$ & $5,4 \%$ & 51 & 40 & 91 \\
\hline Torsdag & $6,0 \%$ & $4,6 \%$ & $5,3 \%$ & 52 & 38 & 90 \\
\hline Fredag & $21,0 \%$ & $18,8 \%$ & $19,9 \%$ & 183 & 154 & 337 \\
\hline Lørdag & $45,8 \%$ & $48,8 \%$ & $47,2 \%$ & 399 & 399 & 798 \\
\hline Søndag & $8,3 \%$ & $6,7 \%$ & $7,5 \%$ & 72 & 55 & 127 \\
\hline Vet ikke & $4,0 \%$ & $7,5 \%$ & $5,7 \%$ & 35 & 61 & 96 \\
\hline Total & $100,0 \%$ & $100,0 \%$ & $100,0 \%$ & 872 & 818 & 1690 \\
\hline
\end{tabular}




\section{Vedleggstabeller til kapittel om cannabisbruk}

Vedleggstabell til figur 6.1. Andel av befolkningen, $16-64^{1}$ år, som rapporterer å ha brukt cannabis noen gang, siste 12 måneder og siste 4 uker. 1985-2012.

\begin{tabular}{|c|c|c|c|c|c|c|}
\hline Bruk av cannabis & 1985 & 1991 & 1994 & 1999 & 2004 & 2012 \\
\hline Noen gang & 8.5 & 9.6 & 13.1 & 15.4 & 16.2 & 19.2 \\
\hline Siste 12 måneder & 2.2 & 3 & 4.4 & 4.5 & 4.6 & 3.5 \\
\hline Siste 30 dager $^{2}$ & - & - & 1.9 & 2.5 & 2.2 & 1.5 \\
\hline Antall $^{3}$ & 1577 & 1602 & 2513 & 2110 & 2575 & 1667 \\
\hline
\end{tabular}

1 15-64 år i 1985-2004 2 Spørsmålet ble ikke stilt i 1985 og 1991. Siste 4 uker i 20123 Antall personer for hele undersøkelsen 15/16-64 år. For enkeltspørsmål kan det være færre som har svart.

Vedleggstabell til figur 6.2. Andel av befolkningen 16-64 år som har brukt cannabis noen gang, siste 12 måneder og siste 4 uker. Kvinner og menn.

\begin{tabular}{|l|c|c|c|c|}
\hline & Noen gang & Siste 12 måneder & Siste 4 uker & Antall \\
\hline Menn & 23.4 & 4.9 & 2.2 & 850 \\
\hline Kvinner & 14.7 & 2 & 0.7 & 814 \\
\hline Alle & 19.3 & 3.5 & 1.5 & 1667 \\
\hline
\end{tabular}

Vedleggstabell til figur 6.3. Andel av befolkningen 16-64 år som har brukt cannabis siste 12 måneder og siste 4 uker. Aldersgrupper.

\begin{tabular}{|l|c|c|c|c|}
\hline & \multicolumn{2}{|c|}{ Siste 12 måneder } & \multicolumn{2}{c|}{ Siste 4 uker } \\
\hline & Prosent & Antall & Prosent & Antall \\
\hline $16-24$ & 14.4 & 167 & 8.7 & 150 \\
\hline $25-34$ & 6.3 & 159 & 1.4 & 144 \\
\hline $35-44$ & 1.5 & 199 & 0.0 & 199 \\
\hline $45-54$ & 2.3 & 175 & 0.6 & 169 \\
\hline $55-64$ & 0.7 & 150 & 0.0 & 152 \\
\hline $16-64$ år & 4.9 & 850 & 2.0 & 814 \\
\hline
\end{tabular}




\section{Vedleggstabeller til kapittel om bruk av legemidler}

Vedleggstabell til figur 7.1. Andel i befolkningen 16-79 år som rapporterte om bruk av sovemidler og beroligende midler. 1985-2012. Antall.

\begin{tabular}{|l|c|c|c|c|c|c|}
\hline & $\mathbf{1 9 8 5}$ & $\mathbf{1 9 9 1}$ & $\mathbf{1 9 9 4}$ & $\mathbf{1 9 9 9}$ & $\mathbf{2 0 0 4}$ & $\mathbf{2 0 1 2}$ \\
\hline Sovemidler & 10.5 & 13 & 10.1 & 10.7 & 12.3 & 10.4 \\
\hline $\begin{array}{l}\text { Beroligende } \\
\text { midler }\end{array}$ & 8.8 & 8.2 & 7.5 & 8 & 8.7 & 6.2 \\
\hline Antall & 1924 & 1918 & 2671 & 2090 & 3015 & 1943 \\
\hline
\end{tabular}

Vedleggstabell til figur 7.2. Andel av befolkningen 16-79 år som har brukt reseptbelagte sovemidler, beroligende legemidler eller smertestillende legemidler siste 12 måneder. Menn og kvinner. Antall.

\begin{tabular}{|l|c|c|c|c|}
\hline & Sovemidler & Beroligende midler & Smertestillende midler & Antall \\
\hline Menn & 8.2 & 5.2 & 23.8 & 986 \\
\hline Kvinner & 12.6 & 7.1 & 27.6 & 961 \\
\hline I alt & 10.4 & 6.2 & 25.7 & 1947 \\
\hline
\end{tabular}

Vedleggstabell til figur 7.3. Andel av befolkningen 16-79 år som har brukt reseptbelagte sovemidler, beroligende legemidler eller smertestillende legemidler siste 12 måneder. Aldersgrupper. Antall.

\begin{tabular}{|c|c|c|c|c|}
\hline & Sovemidler & Beroligende midler & Smertestillende midler & Antall \\
\hline $16-24$ & 6.3 & 6.9 & 19.6 & 317 \\
\hline $25-34$ & 4.3 & 2.6 & 23.4 & 303 \\
\hline $35-44$ & 8.0 & 3.8 & 29.4 & 398 \\
\hline $45-54$ & 12.2 & 5.2 & 23.9 & 344 \\
\hline $55-64$ & 13.6 & 9.6 & 28.4 & 302 \\
\hline $65-79$ & 19.1 & 10.5 & 28.9 & 277 \\
\hline
\end{tabular}

Vedleggstabell til figur 7.4. Personer 16-79 år som har brukt vanedannende legemidler sammenhengende mer enn én uke siste 12 måneder etter varighet av lengste bruksperiode. Antall.

\begin{tabular}{|l|c|c|c|c|c|}
\hline & $\mathbf{1 - 2}$ uker & $\mathbf{3 - 4}$ uker & $\mathbf{1 - 3}$ måneder & Mer enn tre måneder & Antall \\
\hline Sovemidler & 31.8 & 17.8 & 18.7 & 31.8 & 107 \\
\hline Beroligende midler & 20.3 & 20.3 & 15.3 & 44.1 & 59 \\
\hline Smertestillende midler & 54.8 & 10.3 & 8.3 & 26.6 & 252 \\
\hline
\end{tabular}




\section{SIRUS}

Postboks 565 Sentrum, 0105 Oslo

ISBN 978-82-7171-407-9

ISSN 1502-8178 